\title{
Pockets of Peasantness: Small-scale Agricultural Producers in the Central Finger Lakes Region of Upstate New York
}

Master's Thesis at Institute for Landscape Planning, Department of Landscape, Spatial and Infrastructure Sciences University of Natural Resources and Life Sciences, Vienna

Author: Johann Strube, BSc

Supervisor: Hon. Prof. Dr. phil Dr. habil. Veronika Bennholdt-Thomsen (BOKU)

Field Supervisor: Associate Prof. Rachel Bezner Kerr, PhD (Cornell University)

Vienna, June 2016 
Thank you to everyone who supported me in writing this thesis. Thankyou, Veronita, for being a fantastic supervisor, for keeping up with your im portuat worlt and empowering me to write things I would not have dared to even think a few years ago. Thank you, Rachel, for helping we jet stauted with my troldwout and providing feectback in the early stage of my research. Thantiry Phil, for in viting me to the clepourtment at Cornell and giving me your perspective on uny project. Thank you to all guad stadents at Bolel and Cornell, who porovided me with valuable feedback, in particulav Sava, lan, Atakean, $h$ is and Anjorie.

Thanky ron, Jessica, for shauing your findings about the Ithace Farming Community with me. Thank You, Rachel, for soms tantastic ociding.
Much gratitude and love goes out to those who he'ped me to stay sane and who bore with me when l didn't. In particular Anna, the mice of Stewartlittle Coopenative, Lavkin, Silene, Suzaune, Jimmy. Thankyou, mom and clad, for everything. Thant you Monitia, Johanna, Sigrid and Bernadette for morh. ing togather to promote the sabsistence apporoach and enconraging one another.

A massive thank you goes out to all farmers, garden ers, homeSteaders, wroofers and farmworkeus for letting me visit your farms, shacing your thougtis with me and producing some tine food that kept me well nourished while living in ltheca. This thesis is dedicated to you. 


\section{Abstract}

Farmers in the Central Finger Lakes Region of New York (USA) balance their production between principles of peasant farming and capitalist farming. They struggle to extend their sphere of autonomy and subsistence production, while extended commodity production is often a response to external forces of the state and capital. This struggle, together with a quantitative increase of small farms, can be described as an instance of repeasantization.

Based on inductive, empirical qualitative social research, and in particular, ethnographic participant observation and semi-structured interviews, this thesis describes the economy and social organization of six farms in the area under investigation. Besides selling commodities to pay for many farming inputs and consumer goods, the farms produce for their subsistence and that of their community. They exchange products and services with other farms, they build networks of mutual provisioning, support and mentorship and try to take good care of the land.

This thesis shows that subsistence production and peasant culture is not restricted to the past or the Global South, but also exists in the United States of America, albeit subject to the capitalist market economy. I suggest that these pockets of peasantness are an important source of inspiration for society at large, while the dominant capitalistic social order fails to deliver good living conditions for most people. It is therefore critical to support farmers in their struggle. 


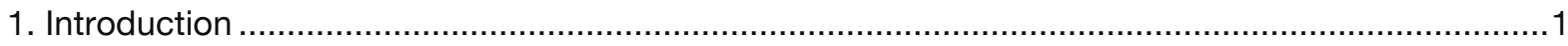

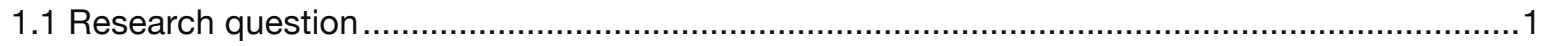

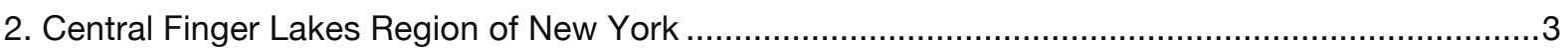

2.1 Geography, demography and natural environment.......................................................

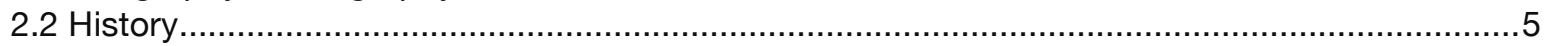

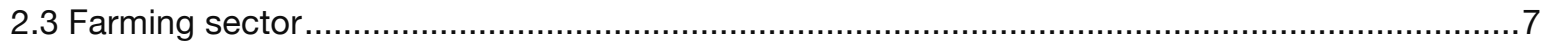

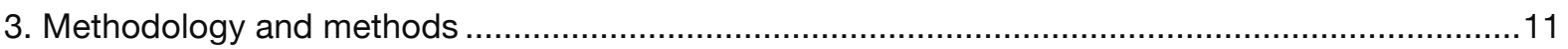

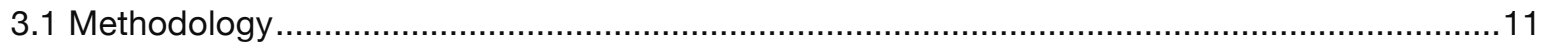

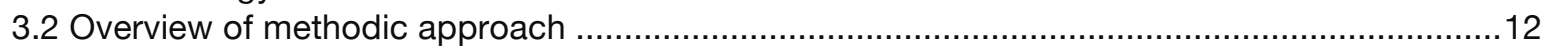

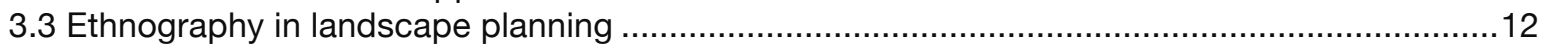

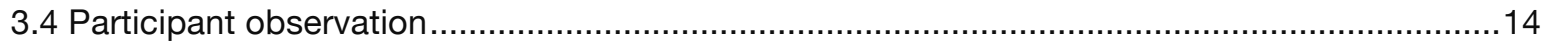

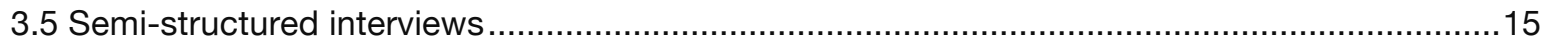

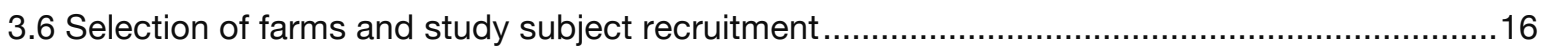

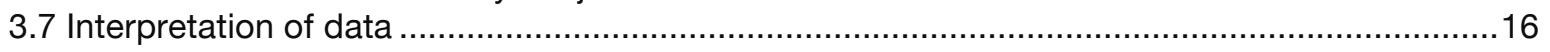

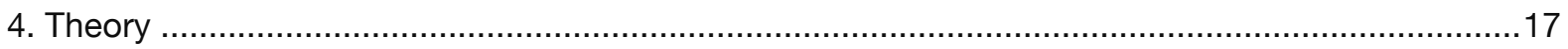

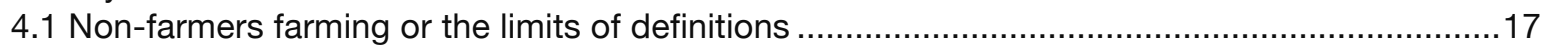

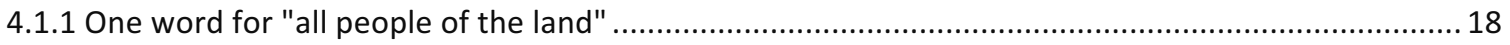

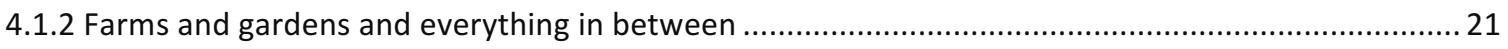

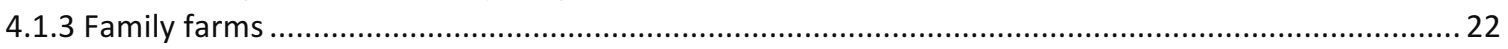

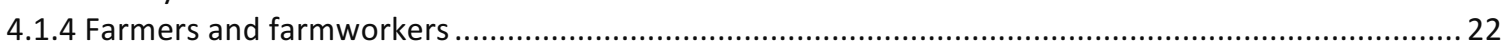

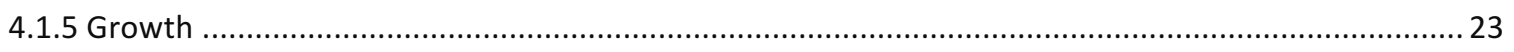

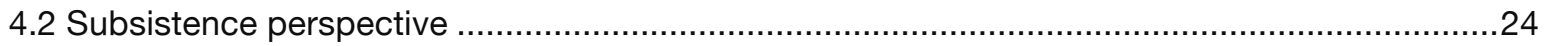

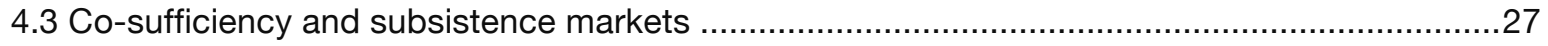

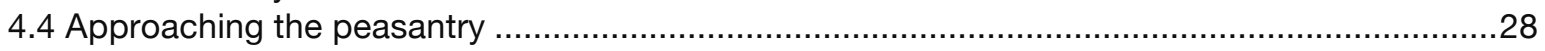

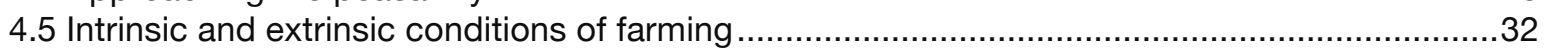

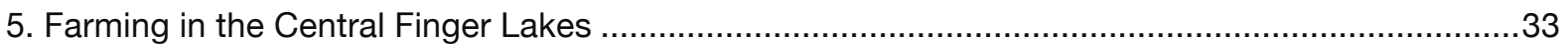

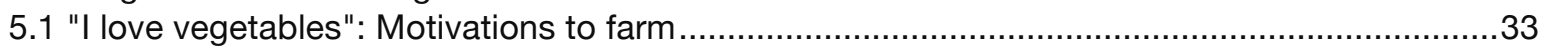

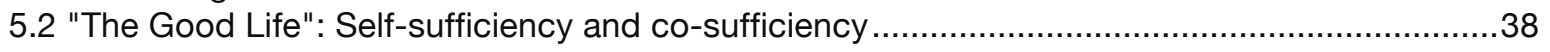

5.3 "Relationships that are beyond just social": Community and cooperation ............................40

5.4 "Locked into the System": Subsistence-oriented farming in a capitalist world .......................46

5.5 "We want to grow, but also to shrink in size": Farmers' relationship to growth......................48

5.6 "My role ends up to be more ambiguous": Labor ......................................................50

5.7 "I used to really not wanna be in debt and now I don't give a shit": Debt .............................52

5.8 "Never enough hours in a day": Small farms, big farms ................................................54

5.9 "I don't know if I want my kids to be farming": Farm future and succession ...........................57

5.10 Economies of scale benefit large-scale farms to repair equipment and apply for support

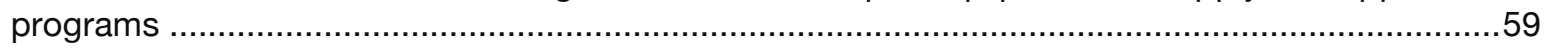

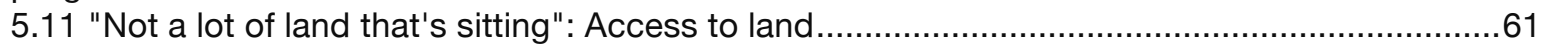

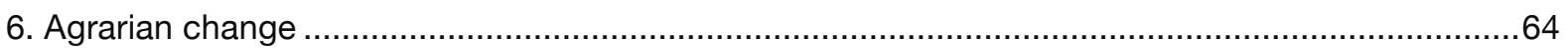

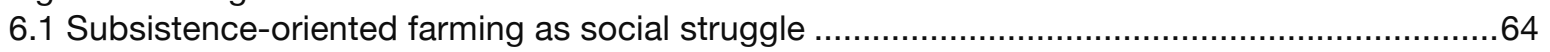

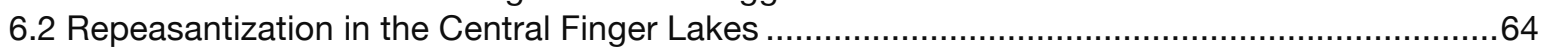

6.3 Pockets of peasantness as seeds for a life beyond capitalism .....................................66

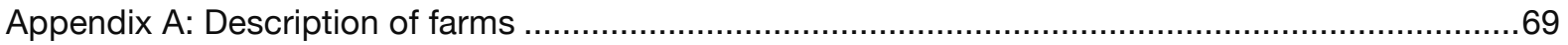

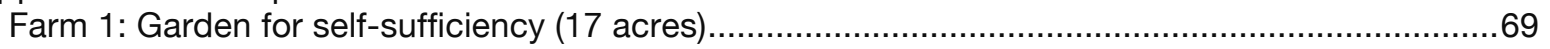

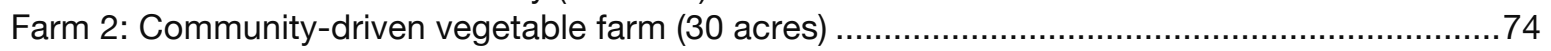

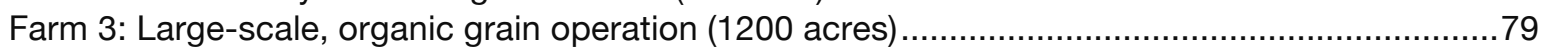

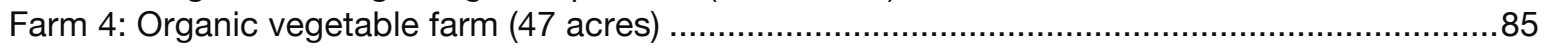

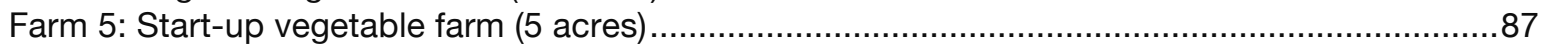

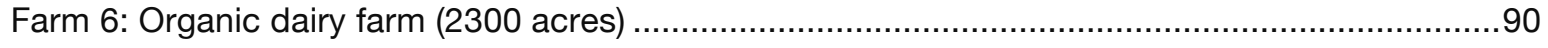

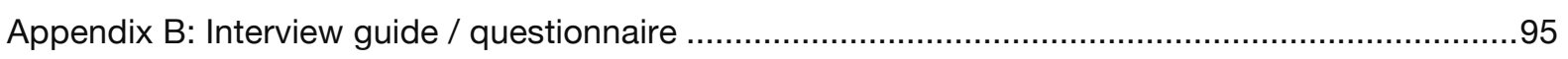

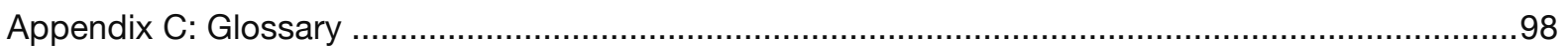

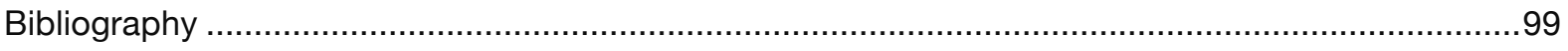

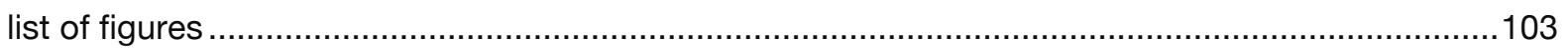




\section{Introduction}

Peasant farming in the United States of America: What seems like an oxymoron at first is in reality a story of a persisting livelihood in an environment of threefold repression. First, there is the economic repression, the hegemonic development policy that pushes farmers either into the commodity production under the ruling globalized conditions or out of agriculture altogether. Secondly, there is the semantic repression, the notion that this policy has been so successful that peasant farming is today limited to the past and the Global South, and often associated with poverty and misery. Thirdly, there is the collective, psychological repression of the possibility of a life beyond competition and the rule of capital.

If one takes a genuine look at the reality of farmers (for a discussion of the terms peasant and farmers see chapter 4.4 Approaching the peasantry) on the ground, however, one begins to realize the latter two assertions are ideological prophecies that support the economic repression of peasant farming that has been far from all-encompassing. Against the forces of compliance to the rules of the capitalist market and the state, many farmers strive towards a life that is built on values such as reciprocity, solidarity, co-sufficiency and sustainability. As small as these pockets of peasantness may be, they can be a role model for our society in a time when the hegemonic social order of capitalism fails to provide acceptable living conditions for an ever-increasing number of people.

For this thesis, I visited six farms in the Central Finger Lakes Region of Upstate New York (USA). Based on participant observation and qualitative interviews, I have described and analyzed the economic and social organization of these operations. I found that, despite being integrated in commodity markets, these farms are committed to producing subsistence (cf. chapter 4.2. Subsistence for a definition of how subsistence is perceived in this thesis) for their families and a wider community. Their production is shaped by principles of both peasant farming and capitalist farming. The former align more closely to a farmer's intrinsic values, whereas the latter are often a reaction to off-farm forces. The productive process is an arena of social struggle, a way to extend autonomy and to align one's economy more closely with one's own ideals. This striving towards more peasant-like production and a quantitative increase of small farmers in the area under investigation signifies an instance of repeasantization (VAN DER PLOEG 2008) in the Central Finger Lakes.

I hope that this thesis will help place peasant farming in the United States back into people's consciousness. This would do justice to the many agricultural producers who struggle to build a selfdetermined livelihood against the coercions of capital. It would appreciate the hard work that farmers do to (re)produce subsistence for us all, the material foundation of a good life that includes selfreliant communities, healthy soils and sufficient, nutritionally and culturally rich foods - even though their capacity to do this is restricted. And it would hopefully raise awareness of the importance of the peasant economy for the transition to a post-capitalist society.

\subsection{Research question}

The interest in this research evolved in 2011, when I first visited the United States of America, volunteering on a farm near Buffalo, New York (NY). What I experienced there neither matched my prejudiced image of North American corporate agriculture, nor was it like farming I was used to. I met young and proud farmers, trying to live off the land, with a strong sense of mission to provide their local community with fresh food. I kept this in the back of my mind while making my way through college. During that time, I got involved in research projects about small farming in Austria, Italy and Morocco, and increasingly appreciated the peasant way as a more sustainable and equitable alternative to the dominant growth economy.

Apparently, that stance is not in vogue. The hegemonic development paradigm still sees depeasantization and the consequent migration from rural areas into cities as signs of progress. On the other hand, the contemporary left-wing alter-globalization movement in Europe does not seem to have 
much appreciation for the peasantry, either. Just like many other leftist movements of the past 150 years, the way to overcome capitalism was sought between socialist revolution and radically new and unorthodox solutions. There was no interest in understanding traditional economies that have conserved nature and created strong and just communities for centuries. Peasant groups such as La Via Campesina were accepted as a splash of color, but their demands were dismissed as mere outrages over exploitation in the Global South, and not as offering viable solutions to the economy and culture of the Global North.

My experiences with small farmers in both the Global North and South taught me that this was a misconception of the potential of the peasant way. If I could show a) that the peasant culture is a tradition available to us even in the most industrialized and capitalist countries, and b) that it offers answers to the multiple crises (such as global warming, overuse of nature, growing inequality and hunger) of our time, I would make a contribution to the urgently needed transition of our destructive economy. This is where I remembered my stay in Upstate New York. I found the United States an excellent case for this undertaking. For many, the United States is seen as the epitome of capitalism, where peasant farming would be least expected. That is, if I were to show traces of peasantness in this environment, it would challenge the widespread notion of the alleged disappearance of the peasantry in a capitalist society. As a secondary goal, I wanted to showcase small farming in North America at my university in Austria in order to overcome common stereotypical prejudices about American agriculture being equated with genetic engineering, satellite-controlled combines and airplanes spraying herbicides over fields that stretch beyond the horizon. For my North American audience, I hope that my perspective on peasant farming developed in Europe within the academic tradition of the Kassel school of landscape planning will broaden the current debates on local food and food sovereignty.

I was not concerned with conducting my research at a specific location. When the Department of Development Sociology at Cornell in Ithaca, NY, invited me as a visiting student to conduct my fieldwork, I decided to situate my thesis fieldwork in the region that is home to the university, the Central Finger Lakes Region. The large farmers' market and the many CSA ${ }^{1}$ programs in the area quickly proved that this would be a good place to get in touch with farmers to learn from.

\section{Methodology}

How do you transform a vague interest into a workable research project? I wanted to work inductively, that is, deriving my questions, the course of the research itself, from the field. To do that, I could not start with anything but the most basic questions: Who are the farmers and other small agricultural producers of the Finger Lakes Region? What drives them? And, how do they operate? With this focus, I would at least come up with a social portrait of small farming around Ithaca. Social anthropology is a discipline that has been developed to derive meaning from the observation of people. It has established a large toolset to use in order to probe into my questions. I intended to fully explore the suitability of these methods to extend the methodology used in landscape planning.

After describing my observations on small farming in the Central Finger Lakes Region, I mean to contextualize them using the subsistence perspective by BENNHOLDT-THOMSEN and MIES (1999) and the repeasantization framework by VAN DER PLOEG (2008). This provides a framework to discuss my initial questions about the peasantry in the Global North and how it can be a solution to today's multiple crises.

\footnotetext{
${ }^{1}$ See Appendix B (Glossary) for clarification of abbreviations.
} 


\section{Central Finger Lakes Region of New York}

\subsection{Geography, demography and natural environment}

The farms visited for this thesis are situated in the Central Finger Lakes of Upstate New York, between Seneca Lake and Owasco Lake. Spread over three counties-Seneca, Schulyer and Tompkins - they share a common urban center, Ithaca. While not all farms have chosen to do so, they are all eligible to sell at the Ithaca Farmers' Market, which requires all products to be produced within 30 miles $(50 \mathrm{~km}$ ). This region, which may be called the Ithaca Local Market Area (in this thesis, I use this term synonymously with Central Finger Lakes Region), is the area investigated for this study.

Ithaca consists of two distinct municipal corporations. The City of Ithaca comprises the downtown sections of Ithaca, while the outer neighborhoods and the suburban fringe make up the Town of Ithaca. As of 2010, the population of the two parts was 30,720 and 19,930 people, respectively (U.S. CENSUS BUREAU, 2014a). The city's economy is dominated by tourism and, above all, by its largest employer, Cornell University. As a college town, the population grows significantly during the school year.

The combined population of Schulyer, Seneca and Tompkins Counties is 158,054 people (U.S. CENSUS BUREAU, 2014b), which means that the majority of residents live in the towns and villages outside of Ithaca, the only city in the area. As of the 2010 census (U.S. CENSUS BUREAU, 2014c), the racial makeup of the three counties was $86.6 \%$ White, 3.7\% Black or African American, $0.3 \%$ American Indian and Alaska Native, 5.8\%, Asian 0.03\% Pacific Islander, $0.9 \%$ other and $2.6 \%$ identified with two or more races. Hispanic or Latino of any race was $3.5 \%$ of the population.

There is a marked difference in the demographic composition of the three counties. Urban Ithaca has a higher share of ethnic minorities than the rural parts of the Finger Lakes. In the city of Ithaca, $26.03 \%$ identified as some other race than white. In rural Schuyler County, this number was only $2.94 \%$.

The area's most significant geological features are the wide north-south facing valleys, of which each is filled with long, narrow lakes that gave the region its name. Cayuga Lake (40 miles [64 km] long, $435 \mathrm{ft}$ [133 m] deep) and Seneca Lake (38 miles [61 km] long, 618 feet [188 m] deep) are the largest of the Finger Lakes and divide the land into sections of land and water from east to west. These valleys were formed when glaciers from the Hudson Bay area moved southward along existing streambeds during the last ice ages. They were able to carve out wide valleys because the shale and limestone of the area offered little resistance. They left behind glacial debris that created dams and, ultimately, lakes (FLINT, 1971). The valleys extend south as the glaciers went further than the current lakes, thus creating lowlands, or "flats," at their southern ends.

Another characteristic feature of the landscape are the deep gorges and ravines that cut through the soft shale and limestone of the hills along the valleys. They are formed by streams that drain the landscape into the lakes (ABT, 1926, $5 \mathrm{ff}$ ). In some parts, heavier rocks erode at a slower pace than the adjoining softer materials, creating cascades and waterfalls. One of them, Taughannock Falls (215 $\mathrm{ft}[66 \mathrm{~m}])$, is the tallest single-drop waterfall east of the Rocky Mountains.

The land is now mainly covered by thick, secondary temperate broadleaf forest dotted with pastures and meadows in the steeper parts and cropland in the fertile lowlands and plateaus. 


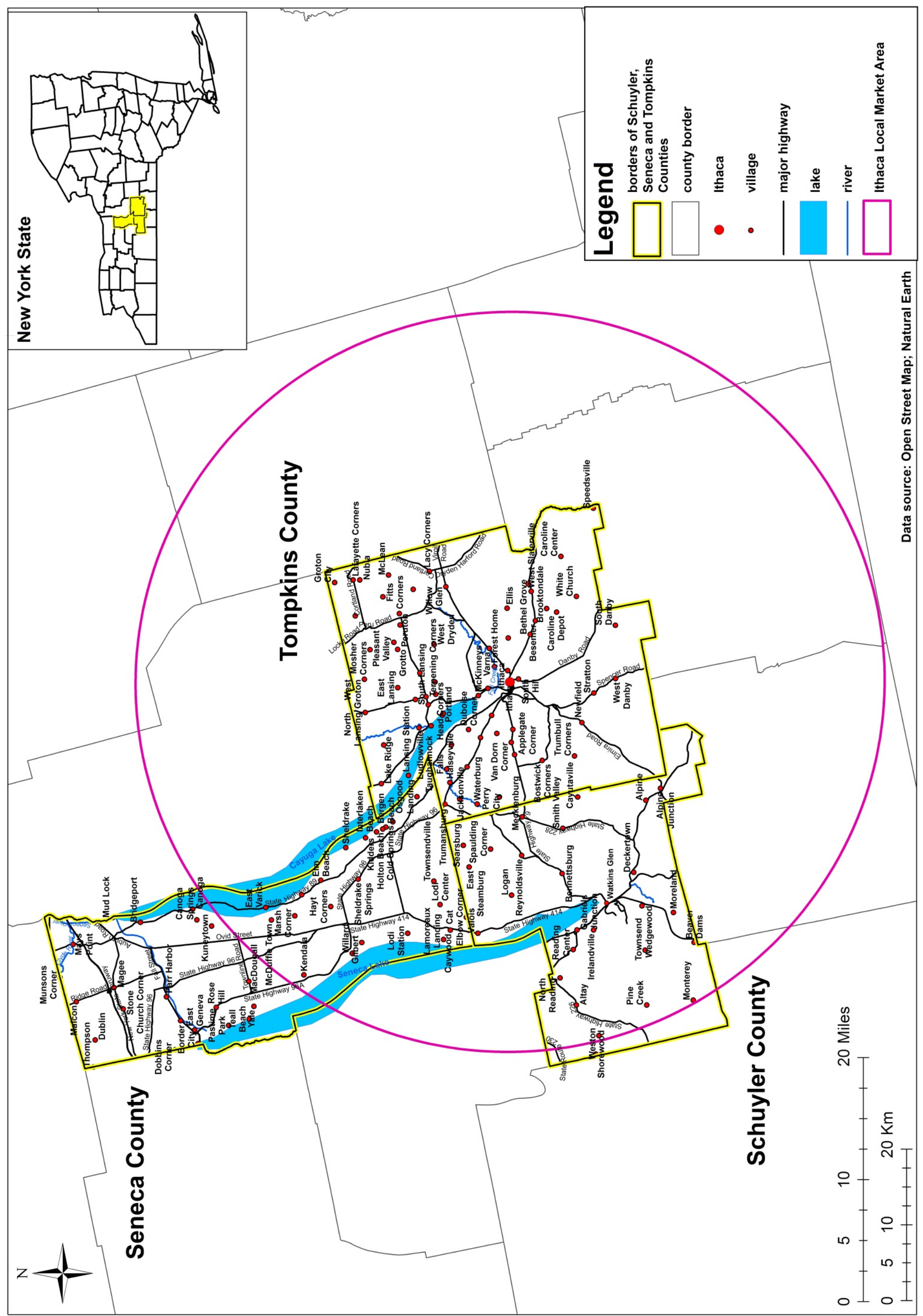


The region is characterized by its moderate continental climate. The winters last from November through early April, are relatively cold (with average temperatures reaching $22.3^{\circ} \mathrm{F}\left[-5.4^{\circ} \mathrm{C}\right]$ in January) and snowy, averaging 64.4 inches $(164 \mathrm{~cm})$ of snow every year. The summers, on the other hand, are warm and humid (average temperature in July is $68.8^{\circ} \mathrm{F}\left[20.4^{\circ} \mathrm{C}\right]$ ). Annual precipitation is 37.30 inches (947.42 mm; NORTHEAST REGIONAL CLIMATE CENTER, 2015).

\begin{tabular}{|c|c|c|c|c|c|c|c|c|c|c|c|c|c|}
\hline Normal & Jan & Feb & Mar & Apr & May & Jun & Jul & Aug & Sep & Oct & Nov & Dec & Annual \\
\hline Max Temp F & 31.50 & 34.00 & 42.00 & 55.50 & 67.40 & 76.00 & 79.90 & 78.60 & 71.10 & 59.00 & 47.50 & 35.80 & 56.50 \\
\hline Max Temp $\left({ }^{\circ} \mathrm{C}\right)$ & -0.28 & 1.11 & 5.56 & 13.06 & 19.67 & 24.44 & 26.61 & 25.89 & 21.72 & 15.00 & 8.61 & 2.11 & 13.61 \\
\hline Min Temp F & 15.40 & 16.50 & 23.10 & 33.90 & 43.50 & 53.30 & 57.70 & 56.30 & 49.00 & 38.30 & 31.70 & 21.50 & 36.70 \\
\hline $\operatorname{Min} \operatorname{Temp}\left({ }^{\circ} \mathrm{C}\right)$ & -9.22 & -8.61 & -4.94 & 1.06 & 6.39 & 11.83 & 14.28 & 13.50 & 9.44 & 3.50 & -0.17 & -5.83 & 2.61 \\
\hline Avr Temp F & 22.30 & 25.30 & 32.60 & 44.70 & 55.40 & 64.60 & 68.80 & 67.40 & 60.00 & 48.70 & 39.60 & 28.70 & 46.60 \\
\hline Avr Temp $\left({ }^{\circ} \mathrm{C}\right)$ & -5.39 & -3.72 & 0.33 & 7.06 & 13.00 & 18.11 & 20.44 & 19.67 & 15.56 & 9.28 & 4.22 & -1.83 & 8.11 \\
\hline Precip. (inches) & 2.08 & 1.98 & 2.64 & 3.29 & 3.19 & 3.99 & 3.83 & 3.63 & 3.69 & 3.42 & 3.16 & 2.40 & 37.30 \\
\hline Precip. (mm) & 52.83 & 50.29 & 67.06 & 83.57 & 81.03 & 101.35 & 97.28 & 92.20 & 93.73 & 86.87 & 80.26 & 60.96 & 947.42 \\
\hline Snowf. (inches) & 17.60 & 14.20 & 11.70 & 3.40 & 0.00 & 0.00 & 0.00 & 0.00 & 0.00 & 0.40 & 4.50 & 12.60 & 64.40 \\
\hline Snowf. (mm) & 447.04 & 360.68 & 297.18 & 86.36 & 0.00 & 0.00 & 0.00 & 0.00 & 0.00 & 10.16 & 114.30 & 320.04 & 1635.76 \\
\hline
\end{tabular}

Table 1: climate table Ithaca, NY (NORTHEAST REGIONAL CLIMATE CENTER, 2015)

\subsection{History}

While this thesis is about farming in the Central Finger Lakes today, it is helpful to briefly outline the history of the region. The earliest known humans that entered the area were the so-called Clovis people, Paleo-Indians who roamed the then boreal Central New York between 11,000 and 6,000 B.C. as hunters. Eventually, when the warming climate supported more plentiful forage, the Laurentian culture, consisting of the Lamoka, the Brewerton and the Frontenac, came into being. These cultures of hunters and gatherers lived in a semi-nomadic fashion, developed tools, musical instruments and jewelry, and occasionally fought each other in the competition for game. In the three centuries between 1300 and 1000 B.C., small bands from central Pennsylvania, called Susquehanna, entered the area in their hunt for game.

Starting around 1000 B.C., the inhabitants of the Finger Lakes area started to build settlements, developed a system of agriculture based on corn and squash (the seeds must have been traded all the way from Mexico) and significantly improved their pottery. This period, which lasted until approximately 1600 A.D., is known as the Woodland Phase. Around 1300 A.D., the Haudenosaunee (also known as Iroquois) settled in the area, even though it is not known if they were descendants from earlier people in the area or if they immigrated from further south. They developed five distinct cultures and divided into the Mohawk, Oneida, Onondaga, Seneca and Cayuga, of which the latter lived in the area around Cayuga Lake, which has been named after them. Around 1450 A.D., these nations came together once again and formed a mutual confederacy. The Haudenosaunee developed a complex social organization with matriarchal families, clans, villages and towns, nations and the confederacy, and their land spread over most of today's upstate New York (KAMMEN, 1985). In 1712 the Five Nations were joined by the Tuscaroras, a related nation who had been pushed north from the Carolinas by English settlers. With them came the Sapony and Tutelo Nations, who settled among the Cayuga without joining their Confederacy.

The Cayuga today still regard this region as their homeland. This legacy notwithstanding, the history of the Central Finger Lakes (much like the history of the United States more generally) is most often told in a way that starts with the first white settlers. Native people who lived in the area before are still represented as a part of the "pristine" natural environment, not as a human population with its own unique culture, social organization and agency. (Take "A Short History of Tompkins County" by Jane Marsh DIECKMANN [1986] as an example. Despite mentioning the Cayuga briefly, the book's chronology starts in 1615 when the first white man, Etienne Brule, enters the region.)

The first contact between Europeans and the Cayuga people most likely occurred in the early 17th century, when French missionaries moved south from Montreal. It was not until 50 years later that the Cayuga started to convert to Christianity. The French activity in the area ended in 1684, when the Cayuga drove out the last missionary. As a result of the War of the Spanish Succession, the French abstained from any claim to power over the homeland of the Haudenosaunee (How they ever con- 
structed such a claim in the first place remains ambiguous.) in the Treaty of Utrecht in 1713 and allowed the English to succeed them (ABT, 1926, 16).

In the mid-1770s, white settlers started to penetrate Haudenosaunee land and squatted on it (DUNBAR-ORITZ, 2014, 76). When the Revolutionary War broke out in 1775, the Haudenosaunee suddenly found themselves torn between the British and the newly founded United States of America. Some nations sided with the British as they were afraid of American expansionism. Others remained neutral, fought on both sides or joined the American camp. It is debated whether the Cayuga Nation as a whole took a stance with either party or if different clans fought on different sides. This conflict drove a wedge between the Confederacy of the Six Nations and ultimately led to its breakup.

The fear that the Americans would attempt to seize Cayuga land proved true when General Washington gave order to Major General John Sullivan to lead an expedition with the mission to remove the Haudenosaunee from their homeland. While often presented as an operation to pacify the new land for American settlers, the Sullivan Expedition must more accurately be described as a genocidal mission. In his briefing, George Washington instructed John Sullivan:

"The expedition you are appointed to command is to be directed against the hostile tribes of the six nations of Indians, with their associates and adherents. The immediate objects are the total destruction and devastation of their settlements and the capture of as many prisoners of every age and sex as possible. It will be essential to ruin their crops now in the ground and prevent their planting more. ... parties should be detached to lay waste all the settlements around with instructions to do it in the most effectual manner, that the country may not be merely overrun but destroyed. ... you will not by any means listen to overture of peace before the total ruin of their settlements is effected." (WASHINGTON, 1779)

Major General Sullivan followed order. Without much resistance, his troops went through the Cayuga people's land in September 1779 destroying towns and villages, burning crops and orchards and capturing, driving out and indiscriminately killing warriors and civilians.

Sullivan confirmed the success of his mission:

"I flatter myself that the orders with which I was entrusted are fully executed, as we have not left a single settlement or field of corn in the country of the Five Nations, nor is there even the appearance of an Indian, this side of Niagara." (SULLIVAN, 1779, 303)

Those Cayuga who were able to escape sought protection among the British, but many refugees died of hunger during the course of the following winter. On 25 February 1789, the Cayuga Nation formally ceded their land to the State of New York (ABT, 1926, 27). This purchase was challenged as illegal by the Cayuga Nation in 1980 and law suits have been filed. Regardless of the legality of the purchase, the land was established as a Military Tract as early as 1781, parceled and given to settlers as compensation for joining George Washington's army in the Revolutionary War ten years earlier. Parcels were given as lots, but few settled on the land they were awarded. Most lots were traded and sold and many soldiers who were awarded land in this area never even saw it, but sold it instead and sought their fortune elsewhere. Others saw their opportunity and secured the most valuable sections. Most land titles today can be traced back to the original Military Tract.

When the first white settlers arrived in the years that followed, they readily used the clearings cut by the Cayuga for their own fields. ${ }^{2}$ It was around 1800 that most villages in the area were founded. In the decades following the Revolutionary War, counties were created, split and constantly changed.

\footnotetext{
2 This often omitted fact contradicts the common notion that the European colonists settled on pristine land. In reality, they forcefully removed a people out of greed for their land (including the value of its improvements) and racism. They did not only replace the owners, but the social organization of the land and of the people who lived on it. While the Haudenosaunee were a largely egalitarian and communal society in which most resources and power were controlled by women (LEACOCK 1987), the colonist imported their social order from Europe, including pronounced social stratification and patriarchy.
} 
The surveyor-general of New York State, Simeon DeWitt, who was responsible for surveying and parceling the Military Tract, envisioned a city he already had called Ithaca. Giving places ancient names was popular in New York around this time and Ithaca is no exception (nor are others in the area such as Dryden, Romulus or Ulysses). He advertised Ithaca as a place of opportunity; at least, for himself, as he managed to secure the most valuable lands for himself (as surveyor-general, one might feel inclined to add that he had a slight advantage) in the lowlands just south of Cayuga Lake, that he planned to develop. The town grew slowly over the coming decades and developed into a place for trade and transit. Industrialization started in the 1880s with the formation of the Ithaca Gun Company and Morse Chain (KAMMEN, 2008).

Perhaps the most powerful accelerator of growth was when Ezra Cornell, a local businessman, endowed some of his land to found Cornell University in 1865. Cornell soon established itself as one of the leading universities in the United States and, later, in the world, attracting people, money and innovation to Ithaca. Two other institutions of higher education were founded later: Ithaca College in 1892 and Tompkins Cortland Community College in 1967.

While Ithaca grew into a city and the economic center of the area, the surrounding villages remained small and were centered around agriculture and associated trades (DIECKMANN, 1986) until they slowly turned into bedroom communities from which residents commute to Ithaca for work or business.

\subsection{Farming sector}

The Central Finger Lakes region is a rural area. While less and less people make their living from agriculture, the land is still characterized by farms, cropland, pastures and forests. At the time of the latest published U.S. census (U.S. CENSUS OF AGRICULTURE 2012b), 40.2\% of the land of Tompkins, Schuyler and Seneca Counties was farmland.

Dairy farming and associated feed crops (corn, soybeans, hay) dominate economically, while vegetables and grapes are also common crops. Only $4 \%$ of the farms were USDA Certified Organic.

As chapter 5.2 (Self-sufficiency and co-sufficiency) will show, many farmers engage in agricultural subsistence production. However, neither the USDA census, nor this study has collected adequate data on these activities to allow for quantitative statements about subsistence production, unlike commercial production.

In 2012, there were 1535 farms in the three counties with a median size of 79 acres (32 ha). Using the classification of the census, the most common farm size (39.5\%) fell into the range of 50 to 170 acres (20-69 ha), with $35.4 \%$ smaller than 50 acres (20 ha) and $8.5 \%$ smaller than 10 acres (4 ha). Large farms made up $7.3 \%$ of all farms (112 farms), and were defined as being more than 500 acres (202 ha).

The farms in Tompkins, Schuyler and Seneca Counties sold products for $\$ 230,789,000$, averaging $\$ 145,858$ per farm. The USDA categorized $87.8 \%$ of the farms as small, with sales of less than $\$ 250,000$. More than a quarter, $28.7 \%$, made less than $\$ 2500$. The remaining $12.2 \%$, however, accounted for $77.6 \%$ of all sales, signifying an uneven income distribution.

The average operator age in the three counties was 55.7 years, with $26.5 \%$ being over 65 years old. Women operated $19 \%$ of the farms. So-called sideline farms, that is, farms with the principal operator having a different primary occupation than farming, made up $42 \%$ of all farms.

About two-thirds of the farms relied fully on family labor and unpaid workers, and $31.4 \%$ of the farms hired additional labor. In 2012, 2484 farmworkers were employed in Tompkins, Schuyler and Seneca Counties, averaging 5 workers per farm that hired additional labor. Migrant workers, that is, farmworkers who do not return to their homes every day, were hired by $20.3 \%$ of the farms. In total, 6165 
people worked on farms in this area, either paid or unpaid or as operators; i.e., $3.85 \%$ of the population.

The area around Ithaca is known for its support of local agriculture. The city's cooperative, sellerowned farmers' market is popular with the local population as well with tourists, attracting about 7000 people each week. The market has grown from a weekly market with 30 vendors in 1973 to five markets throughout Ithaca with 160 vendors today (market manager, personal communication, 11 May 2016). Ithaca is home to GreenStar cooperative, a member-owned food store with more than 11,000 members (GREENSTAR COOPERATIVE, 2016), comprising about one-fifth of the population (city and town combined). Several farms offer CSA subscriptions to customers, and $20.1 \%$ of all operations in the three counties were engaged in some sort of direct marketing (USDA 2012b).

Like the United States in general, and New York in particular, many farms have either increased in size or discontinued their operations in the past 70 years. Between 1945 and 2012, the number of farms in Tompkins, Schuyler and Seneca Counties decreased by $64.6 \%$, from 4334 to 1535 farms (Figure 1). The decline applies to farms of all sizes apart from operations larger than 500 acres (202 ha), which have increased in number. This is especially true for operations with more than 1000 acres (405 ha), which have increased by $1275 \%$, from only 4 farms in 1945 to 51 farms in 2012 . This trend has affected medium-sized farms between 50 acres ( $40 \mathrm{ha}$ ) and 259 acres (105 ha) the most. Their share of all operations has decreased, while farms greater than or equal to 260 acres (105 ha) and farms smaller than 50 acres $(20 \mathrm{ha})$ have increased relative to the total number of farms (Figure 2).

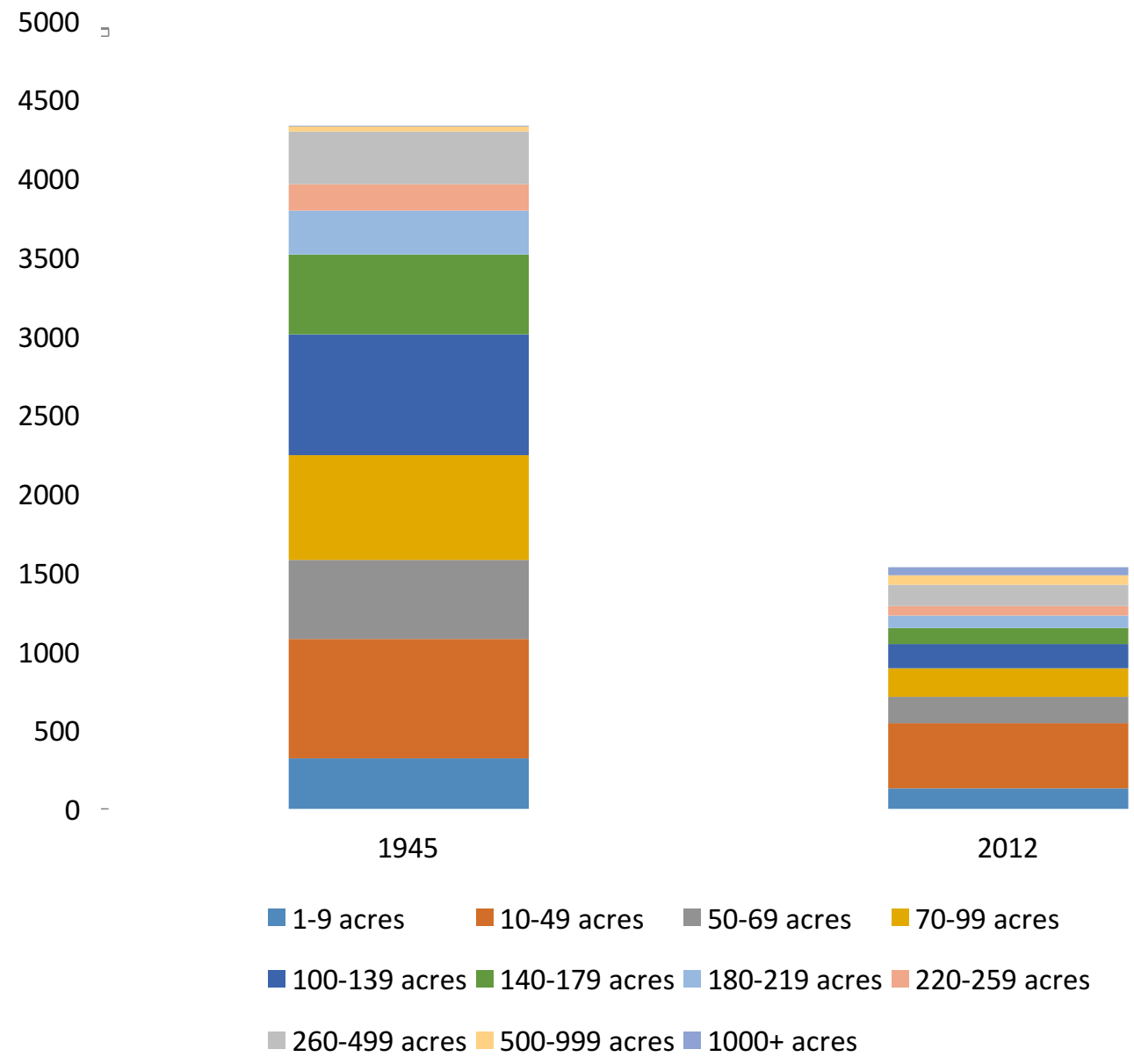

Figure 1: Number of farms by size in Schuyler, Seneca and Tompkins Counties (data: U.S. CENSUS BUREAU 1945, USDA 2012b) 


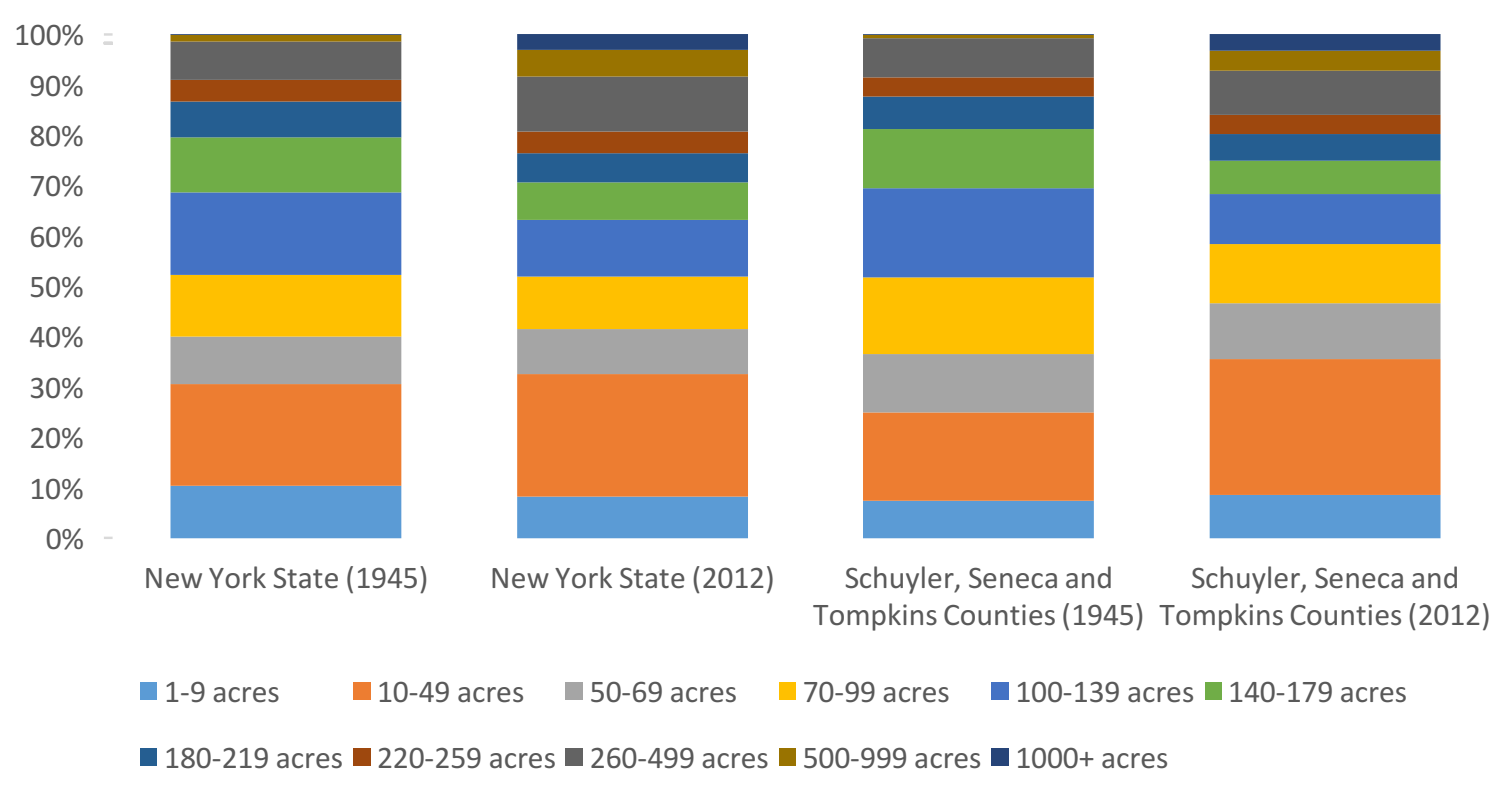

Figure 2: farm size distribution (data: U.S. CENSUS BUREAU 1945, USDA 2012b)

In the last years, however, this trend has reversed, as new farms have started operation. In total, the number of farms in the three counties has increased by 40 between 2007 and 2012, a 2.7\% increase. This change is uneven for the different scales of farms. Small farms with less than 100 acres (40 ha) have increased most, with 87 new farms, a 10.8\% increase. In particular, the smallest farms with less than 10 acres ( $4 \mathrm{ha}$ ), which are most likely to be new farms (as opposed to farms that have changed in size and thus moved into another size range) have increased most significantly, with 37 new farms. There has also been an increase of farms in the 180-259 acre (73-105 ha) range, while all farms of other scales have decreased (Figure 3, U.S. CENSUS BUREAU 1945; USDA 2007; USDA 2012b).

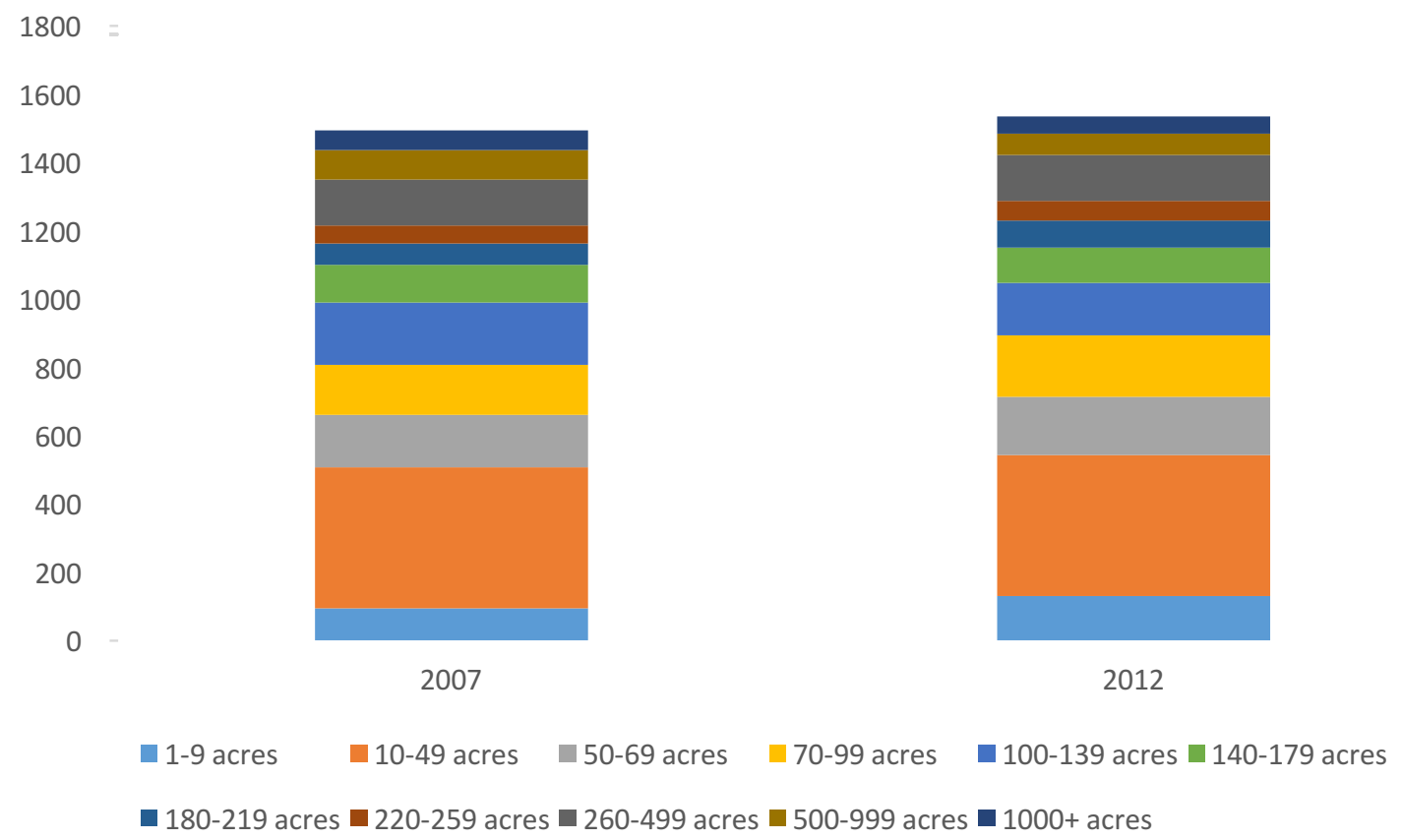

Figure 3: number of farms in Schuyler, Seneca and Tompkins Counties (data: USDA 2007, USDA 2012b) 
In recent years, there has been a strong increase in the value of farm real estate in New York. From 2011 to 2015 , the average per acre value for farmland and agricultural buildings increased by $11.1 \%$. This is the second highest surge in the nation during that time, topped only by South Dakota (USDA, 2015). In the three counties of this study, the farm value has increased by $61 \%$ in Tompkins County, $54 \%$ in Schuyler County and $51 \%$ in Seneca County to $\$ 2757, \$ 2857$ and $\$ 2945$ per acre $\$ 6813$, $\$ 7060$, $\$ 7277$ per ha), respectively (USDA 2002; USDA 2012b) from 2002 to 2012, far beyond inflation for the same time period (Figure 4).

$\$ 3,500$

$\$ 3,000$

$\$ 2,500$

$\$ 2,000$

$\$ 1,500$

$\$ 1,000$

$\$ 500$

$\$ 0$

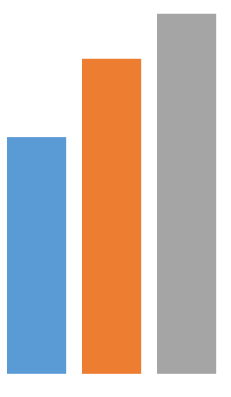

New York

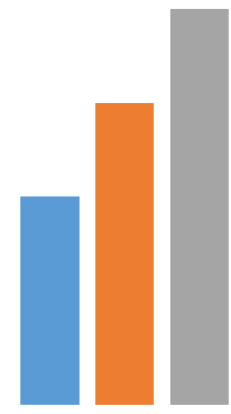

Schuyler

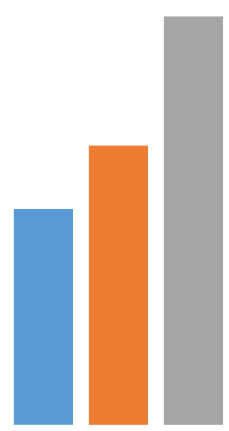

Seneca

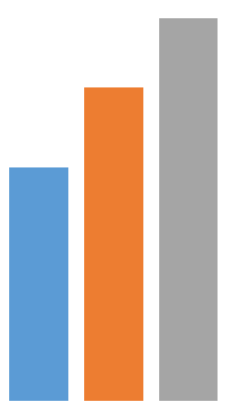

Tompkins

$2002 \square 2007 \quad 2012$

Figure 4: Farm Real Estate Value (data: USDA 2002, USDA 2007, USDA 2012b) 


\section{Methodology and methods}

\subsection{Methodology}

Every inquiry is based upon methodological paradigms that reflect a researcher's stance on reality and knowledge. This thesis is in the tradition of structuralist landscape planning, which is directed at "perceiving the economy of farmers within its social and economic context and history in all its singularity and understanding contexts, guiding principles and values" (SCHMIDTHALER 2013, 55 [author's translation]). The inductive research paradigm states that empirical observation should structure the building of theory. Inductive research begins with the explorative collection of data, which is described and analyzed, and then used to derive principles.

The focus on individual experience places this study in the field of empirical, qualitative social research. MEIER KRUKER and RAUH $(2005,14)$ name three leading methodological considerations from which this kind of research is built and that have also shaped the selection of methods for this research.

First, the methods and theory used for a qualitative research project must be suitable for the questions being investigated. There is not a single, clearly outlined path to knowledge, but each project requires an individual strategy. Therefore, qualitative social scientists in different academic disciplines have developed a multitude of approaches for their fields. I have mainly chosen methods from social and cultural anthropology and will explain why they were best suited for this thesis in the following subchapters.

Second, the research process ought to be open and flexible to adapt to changing situations. It is part of the nature of inductive research that little is known about the field of inquiry. Thus, the course of the research needs to be responsive to findings that may evoke new questions to investigate.

Thirdly, qualitative inquiry needs to include various perspectives on a subject to distinguish between individual opinions (that are shaped by personal interests), beliefs that are shared within a group and to provide depth to findings. Contrasting views, in particular, reveal new layers of a topic to research. To illustrate: If two people agree on a matter, it is easy to accept that position as a truth, at least for these two individuals. But if they disagree, it raises the question why these two persons hold different opinions. This can lead to new insights about the subject at hand and its relation to different people. In this study, I have included the perspectives of many agricultural producers, authors of scientific literature, as well as my own.

The researcher's individual perspective holds a curious role in qualitative inquiry. Just like anyone else, researchers hold certain assumptions about the world, have political opinions and an individual interest in their research that affect not only the conclusions of a study, but also its methodology. For this reason, it is imperative to be transparent about this bias, to present the methods used, the data collected and how one's position was shaped so readers may arrive at their own conclusions. A thesis is therefore not a representation of truth, but an informed interpretation of how an excerpt of the world is perceived by the researcher. This interpretation can be followed or contested by others, a process called discourse. Apart from this matter of subjectivity, the researcher's individual perspective is interesting for another reason. It is often through the discordance of expected and unexpected behavior and sensations of one's own foreignness that a researcher becomes aware of deeply rooted cultural assumptions about how the world is and how it could be different. Thus, the subjective experience can be an asset in the scientific process if it is reflected upon critically and systematically.

The focus on the individual experience also mandates that research take place in the native environment of the people being studied. It acknowledges that human behavior is not the sum of different parts that can be singled out and scrutinized under isolated conditions, but a system of various 
parameters that influence each other and that can only be understood in its complexity. This complexity and its associated singularity severely limit the possibility of deriving theory that can explain human behavior in a universal way. Therefore, I have tried to stay as close as possible to the case presented in this thesis, the farming community in the Central Finger Lakes, and specifically the six farms I have visited. Even though I refer and make contributions to theory that go beyond the specifics of the case and that I find helpful to understand agriculture, I recognize that my findings cannot be extrapolated to other places without considering local conditions.

\subsection{Overview of methodic approach}

I date the beginning of this research to December 2014 (even though vague ideas about this project had occupied my mind since I first visited a farm in the United States in 2011), when Veronika Bennholdt-Thomsen agreed to supervise my thesis and I had to make the first basic decisions (such as specific topic, location, methodical approach, time frame) in order to apply for travel funding and to contact American university departments that could be a good fit with which cooperate.

I spent the subsequent months reading literature on peasant studies, subsistence theory and rural sociology to familiarize myself with the agricultural sector in the United States. By this time I was invited as a visiting scholar to the Department of Development Sociology at Cornell University and had already moved to Ithaca.

Intrigued by my experience in a joint research project with social and cultural anthropology students in Morocco in 2014, I decided to explore ethnography as a way to understand the forces that shape the production by small agricultural producers from their own perspective. My fieldwork started in April 2015, when I began talking to farmers at the Ithaca Farmers' Market, as well as at an event held at GreenStar, and when I volunteered at one of the nearby farms. It was not until weeks later, however, that I realized I was already halfway into my research. I then decided to locate my study in the vicinity of Ithaca for ma variety of reasons: I wanted to use the information I had gathered up to this point, it was convenient because I lived in the area, and it allowed me to immerse myself more fully in the field.

To deepen the insights I had gained from these informal conversations, I started to visit six farms over the course of the summer. At some of them, I was able to work along with the farmers, observe the goings-on and conduct long, semi-structured interviews. At others, I had to make do with quick makeshift interviews and short tours of the farm.

During all these months, I avidly kept notes about my observations, including those of my own thoughts and doubts. It so happened that the questions I asked and the points I focused on evolved over time. Fieldwork, data analysis, reading literature and writing took turns, and one influenced the other.

Writing the thesis, I made use of my interview transcripts and journal entries to compose the farm descriptions found in Appendix A and to interpret my observations thematically along themes that seemed to concern several or each of the farmers and that regarded my overarching research interest.

I then related these observations to the subsistence perspective and repeasantization framework to place them in the wider context of contemporary peasant studies.

\subsection{Ethnography in landscape planning}

Ethnography is a methodic approach to studying social groups that has been developed in cultural anthropology and urban sociology. It designates the immersion of a researcher into a social field to observe and describe it from within. Originally, it was used by Western scholars to investigate indigenous people of the European colonies, but it was soon applied to study any cultural group, foreign 
to the researcher or not. Its aim is to understand the reality of a group from their own perspective, which requires a delicate balance between the immersion into and a distancing from the field of investigation. KROMREY $(2009,391)$ calls this a dilemma: In order to take on the perspective of the studied group, a researcher needs to become part of it as much as possible. Yet, a distanced stance is imperative in order to analyze the particularity and relevance of the observations.

It can be argued that ethnography is either a set of methods or a method itself. Ethnographical fieldwork often consists of participant observation, conducting conversations and interviews, and taking photographs, among other methods. Yet, these elements are not always clearly separated from each other. They can be seen as forms of social interactions by the researcher in the field, supporting the notion of ethnography as one unified method.

The questions of this thesis demanded an ethnographical approach. VAN DER PLOEG $(2009,19)$ argues that "peasant-like ways of farming often exist as practices without theoretical representation.... Hence, they cannot be properly understood, which normally fuels the conclusion that they do not exist or that they are, at best, some irrelevant anomaly." Thus, they can only be comprehended by their own logic, and ethnography is well suited to achieve that.

ATKINSON and HAMMERSLEY (1998, 110ff) identify four key elements of ethnography that were employed in this study:

1) "A strong emphasis on exploring the nature of particular social phenomena, rather than setting out to test hypotheses about them"

Unlike the common practice in landscape planning, I have not proposed hypotheses. Testing hypotheses to verify or falsify them implies a positivist truth that disregards the culturally conditioned ways in which our notion of reality is constructed. Instead I describe how I perceived my observations and the conclusions I drew from them.

2) "A tendency to work primarily with 'unstructured' data, that is, data that have not been cod ed at the point of data collection in terms of a closed set of analytic categories"

A lot of my insights stem from observations and data that were "unstructured" by nature. Working along with farmers, talking with them at farm stands or bars, or driving with them in their cars produced a multitude of situations that were impossible to predict or even prepare for in ways of prestructuring data collection. Instead, I made notes of everything that piqued my interest and tried to make sense of these observations later when going through my field notes. That being said, I conducted semi-structured interviews (cf. chapter 3.5 Semi-structured interviews) to back up my descriptions with quotable statements by the research participants.

\section{3) "Investigation of a small number of cases"}

I included six farms in this thesis, which is a small sample compared to most non-ethnographical studies. However, living in Ithaca I observed and talked to many other farmers, farmworkers and gardeners who also have shaped my views. The construction of a farm as one case is somewhat arbitrary if you describe a community that is characterized by strong links between its members.

4) "Analysis of data that involves explicit interpretation of the meanings and function of human actions, the product of which mainly takes the form of verbal descriptions and explanations, with quantification and statistical analysis playing a subordinate role at most"

The bulk of this study consists of verbal interpretations and structuring of observations and interview transcripts. I have used quantifiable data such as acreages or annual sales to signify qualities, not to make calculations with them. Exceptions are chapter $X Y$, in which I suggested a relationship between farm size and labor demand, and chapter $X Y$, in which I interpreted agricultural census data to analyze quantitative trends. 
During the preparation of this thesis I lived in Ithaca for six months, from March to September 2015. It is not always clear at what times you conduct ethnographic research when you live in the field. When I visited the farmers' market on weekends, I did this out of academic curiosity, but also to meet my own personal economic need to get fresh and local food. Analogous to VAN DER PLOEG (2008, cf. chapter XY 4.4 Approaching the peasantry), this could be described as my co-production of scientific knowledge and life. There were several instances of this co-production. For example, I once met with two of the research participants to watch a soccer game. Of course, we talked about agriculture, which is a shared interest of ours. It is impossible to distinguish whether this was research or a fun evening with friends relaxing from work. The immersion into the field has the consequence that, for a limited period of time, your research becomes your life and your life becomes your research. For the same reason it is difficult to separate methods such as interviews and participatory observation from ethnography if everything you do is ethnographical work.

I volunteered on three of the six participating farms as a farmhand for several days (on one I was able to stay for two nights as well), and on one farm for one day, mostly alongside other workers. The farmers appreciated the extra help and I had a chance to make observations and get answers to my questions. This "fieldwork," in every possible meaning, was noteworthy for two reasons: First, I performed two jobs at once. I was both researcher and farmworker and had to meet the expectations of both roles. It is one thing to conduct academic interviews. It is even more challenging while weeding a row of carrots and paying attention to not pull out the wrong plant. Many times, this meant compromise. For instance, I frequently deferred my note-taking to my way home or to any break I could get. While taking notes at all times can obstruct social interactions, it is physically impossible while doing other manual work. Secondly, I often found these kinds of observations and interviews the only way to learn from farmers. Some did not have the time or the patience to sit down for an interview, but were willing to share their experiences and views while doing their work.

Besides these farm visits I repeatedly went to the Ithaca and Trumansburg Farmers' Markets, attended community events, volunteered at Ithaca's food cooperative GreenStar, visited farms and homesteads that are not featured in this study, talked to other farmers, agricultural researchers, local food and farm activists and representatives of various agricultural organizations. Though I always disclosed my role as a researcher and the reasons for my inquiry, a lot of these observations and conversations occurred in informal settings while living in Ithaca and gathering as much information about agriculture in the area I could get.

\subsection{Participant observation}

Participant observation is the core method of ethnography. It means taking part in activities and social relations of the studied field to document and analyze the behavior of its members. Observation takes place in the natural everyday environment of the study subjects to allow their behavior to be as unchanged as possible, even though the very presence of the researcher influences the setting. Participant observation is directed to social action itself, unlike interviews that record the interviewees' recounts of events and attitudes.

The tradeoff between immersion and distancing explained in chapter 3.3 (Ethnography in landscape planning) is particularly relevant for participant observation. The method is well suited to discover unexpressed cultural assumptions if a certain alien-ness can be maintained. However, if the researcher becomes a fully socialized member of the field, a phenomenon known as "going native," she or he begins to share these assumptions and will be constricted in their reflection upon them.

There were two typical settings in which I conducted participant observation during the research for this thesis. First, I volunteered on four of the participating farms (farms 1, 2, 4 and 5). I contacted the operators beforehand (either by phone, email or personally at the farmers' market) and told them about my intention to work with them and to make observations for my thesis. At my first visit, I explained what exactly I wanted to do, informed them about the confidentiality of the data I planned to collect about them and their right to object to their publication. In line with the protocol of Cornell's Institutional Review Board (IRB), I also provided a written document of these points and asked the 
farmers to sign a consent form I had prepared. I then helped with various chores, mostly weeding and harvesting. At the garden I also did landscaping work, among other tasks. These farms commonly employ either workers or volunteers who are interested in learning about agriculture, so it was a natural setting for me to participate in. I usually worked with other workers or volunteers who I also informed about my research project, but who did not fill in the consent form apart from two wwoofers who feature in more detail in this study.

At most times my manual farm work impaired my ability to take notes right away. Sometimes, I documented observations and thoughts in my journal or audio recorder immediately if I found an event particularly interesting, but mostly I tried to remember as much as possible and summarized my impressions as soon it was acceptable for me to step out of my role as a farmworker. If I had taken more notes while working, it would have impaired my performance as a farmworker and thus I would not have been accepted in this role, which would have affected the behavior of those around me. This was a compromise I did not want to make. To sum up, my role in this setting was that of an active participator as observer. The observation itself was unstructured and overt (cf. LAMNEK, 1995, 254).

The second setting in which I conducted participant observation were at the Ithaca and Trumansburg farmers' markets. My primary interest were not the markets themselves, but the way the farmers who agreed to participate in this study interact with other farmers and customers on the market. This setting was different in so far that these are public events that everyone can attend without permission. Here, my role was that of a visitor, walking from stall to stall, chatting with vendors and other customers, buying and consuming food, listening to musicians or just sitting on a bench, following the events. While I told my conversational partners about my research project, I did not reveal it to everyone at the market, which would have been both impractical and impossible without drastically interfering with the flow of the events. This role enabled me to easily make notes without interrupting anything. I could just retreat to a bench and my journal to record what I saw whenever I wanted. The note-taking allowed me to maintain a certain distance from the field and prevent me from going native, which otherwise would have been easy because a lot of the visitors people like me who wandered around the market and stayed for an extended period of time. It was also a role I had for more than just academic interest. I would have gone to the market anyway to buy groceries and enjoy the atmosphere. Here, my role can be located somewhere on the continuum of complete participant and participator as observer, depending on whether people around me knew I was doing research. The observation was unstructured and neither covert nor overt.

The suitability of participant observation as a way to collect data for my research was limited, however. For example, there was no way for me to participate in the production of farms 3 and 6 . Both are specialized and highly mechanized farms whose operation requires skills (such as driving a tractor or milking cows) that I do not have. Just like the other workers, I also had to go home after the end of the shift (an exception was farm 2 where I was able to stay with the wwoofers for two nights), that is, I could not observe the events on the farms after that time. Generally, I only had a few days per farm for the limited time of the summer 2015. To collect information beyond that, I had to conduct interviews.

\subsection{Semi-structured interviews}

Semi-structured interviews are a qualitative data collection method that combines advantages of structured and unstructured interviews. Like unstructured interviews, they focus on open-ended questions that let the interviewees give the most applicable answer in their own words. What is more, they allow the researcher to ask for more detail or to inquire about topics that come up in the interview. On the other hand, semi-structured interviews make use of a pre-composed guide that guarantees that all topics relevant to a study are covered and thus, different interviews with the same guide are comparable. Yet, unlike in structured interviews, the interviewer can deviate from the guide at will. Semi-structured interviews differ from everyday conversation, like any interview, in that they are purposely arranged settings for the researcher to ask questions and for the interviewee to answer them (cf. LAMNEK 1995, 36). 
Compared with participant observation, interviews offer some advantages. They provide information about events that cannot be observed by the researcher directly, for example, because they occurred in the past or in a setting that is inaccessible for outsiders. They are also easier to document. With the help of a voice recorder or video camera, the interview can be reproduced and transcribed. This makes the original data accessible for other scholars to follow or reject any arguments put forward in this thesis.

Before the first interview, I composed the guide found in Appendix B. I used it to make sure all points that I was interested in were covered, but allowed the interview to explore other directions as well.

I tracked each interview on a voice recorder and transcribed them later word for word. Excerpts of these transcripts have been included throughout this thesis.

\subsection{Selection of farms and study subject recruitment}

In order to account for the diversity within the field, farms had to be selected by purpose rather than formally. Even though my focus was on small farms, I planned to have a heterogeneous sample that would cover different kinds of agricultural production. Both extreme case sampling and maximal variation sampling as defined by PATTON (2002) fulfill this requirement, but the latter was chosen because it also encompasses cases in between these extremes. I decided to include a farm that was too small to appear in the U.S. Census of Agriculture and at least one large-scale farm that did not conform with any stereotypical image of a peasant farm. I also tried to find farms with different production targets and farms that are operated by men and by women. I settled on six farms to cover all of these criteria, but which were still manageable to visit and study.

The research participants were recruited through snowball sampling. That is, I asked informants in the field, including farmers I had already talked to, if they knew farms that would fit my requirements. Since I did not attempt my thesis to be representative, I could live with the selection bias of this method. I approached farms 2 and 4 at the Ithaca farmers' market at their stalls. The garden was contacted via the wwoof website. Farms 3 and 5 were personal contacts of my field supervisor at Cornell, Rachel Bezner-Kerr, and farm 6 I became aware of while driving by their farm.

A problem in finding research participants was rooted in the basic conditions of farming. The winter of 2015 in the Finger Lakes Region had been extraordinarily cold and long. The growing season did not start before May, which coincided with the time I got ready to conduct the bulk of my fieldwork. At that time, most farmers were so busy catching up with their fieldwork that many did not have the time to take part in any research. For many farmers, the late spring meant hard work all summer and no spare time to participate. As a result, the number of farmers I could talk to was diminished significantly.

\subsection{Interpretation of data}

To structure and make sense of my data (journal entries, interview transcripts and graphic sketches), I sorted interview excerpts and observations along themes that emerged repeatedly throughout the data and that concerned the farms' economy and the way they operate within their social environment.

I sorted similar and contrasting positions towards these themes to give a nuanced representation of the economy of the participating farms. Where appropriate, I referred these observations to the body of theory on subsistence production and peasant studies, which I introduce in chapter 4 (Theory). These discussions are the foundation of chapters 4.1 (Farming non-farmers or the limits of definitions) and 5 (Farming in the Central Finger Lakes). 


\section{Theory}

\subsection{Non-farmers farming or the limits of definitions}

Language is an ambiguous thing. There are people farming who are not farmers. There are homesteads without homesteaders, never intended to be homesteaded. There are people who operate as farmers or homesteaders whom no one would call operators of an agricultural operation.

Words change their meaning depending on their context, the person who uses them, and the place and time where and when they are used. The key to deducing the specific meaning from a word is what Jacques LACAN (1987) describes as the Symbolic Order, a set of shared cultural assumptions passed on in years of socialization within a particular sociocultural environment. That is, in most everyday communication, we can make accurate assumptions of the message that someone is trying to convey.

Social science, however, is not everyday communication. Questioning the Symbolic Order is the critical academic's contribution to social change. Unfortunately, interfering with the key to language comes at the risk of becoming incomprehensible and misunderstanding the utterances of others. These are two distinct problems that require separate solutions.

To be comprehensible despite using unconventional interpretations of words and observations, one needs to make a new key by establishing a set of definitions to which the reader can refer. That is the purpose of this chapter.

To mitigate the second risk, one need be aware that others may use words differently; either in the common meaning of the dictionary or in their own individual ways.

To make matters worse, an author might use the same word in different ways, relying on the reader's good judgment to what meaning is referred to. One might switch from academic jargon to a language that is more accessible to laypersons, or use words with slightly dissimilar meanings as synonyms in order to add variety to the writing. It is important to acknowledge and endorse the diversity of meanings that words carry. Trying to use single, unique definitions that hold true under all circumstances disregards the dynamic and lively character of human language. That is especially true if scientists want to write engaging literature instead of cold academic prose that collects dust in the ivory tower's library.

Quantitative social research relies on distinct definitions to classify observations. This permits instances to be counted and compared. For example, food sovereignty advocates often claim that about half of the global population consists of peasants. Yet, it is questionable what this argument is able to convey. Henry BERNSTEIN $(2014,1044)$, for example, is skeptical about the usefulness of this number, as it conflates many different classes of agricultural producers with varying, sometimes opposing, needs and difficulties. What is more, numbers create a scent of positivist objectivity that stifles the merit of a qualitative argument. When, for instance, I claim that a peasant-based agriculture would make a more equitable and sustainable food system, any number about peasants in the United States would either prove or invalidate the case. The abundance, or lack, of peasants in a society is a result of diverse historical events and trends. The remark that peasant farmers have declined in the last century does not tell us if the decrease was caused by inherent contradictions of the peasant economy or by force from a colonialist, capitalist system that regards peasants as obstacles to its interests, or any other reason. It certainly does not reveal anything about the merit of peasant farming for our society, nor the struggles of small farmers. To be sure, there are problems that require classifications, counting and numbers to be answered. However, these are not the questions of this study. I therefore refrain from establishing distinct definitions and categories. I am more intrigued by the comprehension of the livelihood of small and subsistence-oriented agricultural pro- 
ducers, their specific rationale and values, and how their economy can be a model for the rest of our society than I am interested in representing them in numbers.

\subsubsection{One word for "all people of the land"}

There is an analytical need to subsume the research participants of this study in one overarching category. This is not to blur the many differences among them, but to stress the similarities they share. On the most basic and unifying level, each of them could be described as an agricultural producer.

"Agriculturalist" seems like a suitable single-word synonym. The Merriam-Webster dictionary lists "agriculturalist" under agriculture, defined as:

"...the science, art, or practice of cultivating the soil, producing crops, and raising livestock and in varying degrees the preparation and marketing of the resulting products."

(MERRIAM-WEBSTER, 2016)

Thus, an agriculturalist would be someone who engages in these activities, and would apply to each of the research participants. Be that as it may, the meaning of this word was unfamiliar to many of the respondents.

"It doesn't really mean anything to me. It is so vague. I don't mean that in a sassy way. It reminds me it should be a title of a trade magazine. Is it a common word?"

(farmer at farm 5, personal interview, 10 July 2015)

"Agriculturalist? I'm interested in agriculture. We do some trials and stuff like that, with different seed companies. Well, I don't know, I guess I need to know what the definition is. [...] I don't know, I think so, I guess." (farmer at farm 6, personal interview, 11 September 2015)

For other interviewees, the term agriculturalist has an academic ring to it that they did not identify with.

"That sounds too scientific." (gardener at garden 1, personal interview, 14 May 2015)

"No, that term sounds too academic to me. An agriculturalist is someone who studies agriculture to improve it or for own benefits." (wwoofer at farm 2, personal interview, 18 June 2015)

Only two of the respondents related positively to the term. However, they too admitted to not to knowing the actual meaning of it.

"What is that? Someone who practices agriculture? Studies it? Maybe I say yes because I see myself as an environmentalist and in that context...it is an interest of mine. Learning about it. Figuring out how I fit in." (wwoofer at garden 1, personal interview, 7 July 2015)

"I would say so. [...] What is the definition of an agriculturalist? I guess I would identify myself as an agriculturalist. That being someone who studies agriculture and practices agriculture and does research or works with researchers at universities, trying to figure out better ways to farm, somebody who trains young farmers and is thinking of better ways of farming and doing on-farm trials himself and trying different seed types. All those things would say agriculturalist." (farmer at farm 3, personal interview, 30 June 2015)

What about the term farmer? The MERRIAM-WEBSTER dictionary (2016) defines farmer as "a person who cultivates land or crops or raises animals (as livestock or fish)." In this sense, the term is synonymous with agricultural producer. What is more, five of six of the interviewees identified with it. Yet, the rejection of the term farmer by the gardener who participated in this study suggests that the expression is not inclusive for every agricultural producer. 
"Gardener fits best. It feels more tending and nurturing."

(gardener at garden 1, personal interview, 14 May 2015)

In fact, farming and gardening are commonly distinguished from one another, with the former being larger and more commercially oriented than the latter. Bleasdale, a blogger and farmer from Tennessee, phrases the perceived difference as follows:

"To my mind, gardening is more intimate; more time and attention is given to each plant, each row, and the emphasis is on pleasure; that is, the experience of being in the garden. [...] Farming, on the other hand, has an emphasis on production. Unlike gardening, where the journey is just as important as the destination, farming must be productive. If at the end of the season the farm is not profitable, there might not be a next season. Individual plants are sacrificed for the efficiency of the row; rows are sometimes sacrificed for the sake of vehicle paths or irrigation lines. The economy of scale often dominates." (BLEASDALE, 2013)

From this viewpoint, farming is equated with a commercial orientation and a tendency towards output maximization. This is the way the hegemonic growth economy imagines farming. It is understandable that small producers who follow a different model reject the term with that meaning. Still, there are many ways of farming along a continuum of scale and market integration of which commercial, maximization-oriented agriculture is only one. There are many small farmers who still focus on each plant and pleasure while at the same time try to produce enough food for themselves and a larger community of customers. Gene LOGSDON (1985) suggests the use of the term garden farming to overcome the mental separation between gardeners and farmers. He argues that "a farm is a large garden" and "a garden is a small farm," but distinguishes between garden farming on the one hand and industrial factory farming on the other.

An alternative term that encompasses agricultural producers who work the land themselves is campesino or campesina. This Spanish word literally describes a person from the countryside or of the land. The usage of the term has gained momentum with various social movements in Latin America that have been seeking to improve the livelihoods of the rural poor, landless laborers, as well as smallholders who struggle within an increasingly globalized, free-trade economy. Unlike unions, these movements do not fight for improved labor standards and higher wages, but for access to land and improved conditions for smallholders. English speakers use this term increasingly, but mostly exclusively within this political context. Geographer and blogger Sara KOOPMAN (2007) makes the case to import the word into English due to its inclusivity. Perhaps, as more and more rural workers in the United States are of Latin American descent, campesino or campesina will in fact become a common synonym for (small) farmers in the United States. For the time being, however, it is doubtful that it is a term that a lot of English-speakers would identify with because of its foreign origin and its political connotation that not every farmer sympathizes with.

That leaves us with the term peasant, which is often used as the English synonym of campesino. The most prominent connection between these two words is made by La Via Campesina, which describes itself as an international peasant movement, thus using campesino and peasant synonymously. They define a peasant as

"... a man or woman of the land, who has a direct and special relationship with the land and nature through the production of food and/or other agricultural products. Peasants work the land themselves, rely[ing] above all on family labour and other small-scale forms of organizing labour. Peasants are traditionally embedded in their local communities and they take care of local landscapes and of agro-ecological systems. The term peasant can apply to any person engaged in agriculture, cattle-raising, pastoralism, handicrafts-related to agriculture or a related occupation in a rural area. This includes Indigenous people working on the land." (LA VIA CAMPESINA, 2009)

Similar to the activist's framing of campesino, this definition spans a wide net over a vast range of different agricultural producers irrespective of land ownership, but implicitly leaves out industrial farmers who do not identify with the term. Others have been more conservative in the use of the 
word. CHAYANOV (1966), for instance, defined peasants as members of family farms whose farming was carried by a distinct rationale that he described as the peasant economy. BENNHOLDT-

THOMSEN and MIES $(1999,86 \mathrm{ff})$ define peasants as agricultural producers with a shared culture and worldview based on subsistence-orientation and a non-exploitive relationship to nature and other people. This understanding is at the core of the interdisciplinary, academic field of Peasant Studies ausmacht.

In popular contemporary use, the term peasant is frequently understood in a deprecatory way, with undercurrents ranging from poverty, lack of education, backwardness to drudgery. Research participants responded to the questions whether they see themselves as peasants as follows.

"It's not something I necessarily want to be identified with. I think at least in our culture it is associated with poverty. [...] We actually make a lot of money farming. Since the term peasant is associated with poverty I don't think it applies."

(operator at farm 5, personal interview, 17 September 2015)

"I think it implies a lack of education. I wouldn't use it in an offensive way, but it is generally used as an offensive term." (wwoofer at garden 1, personal interview, 7 July 2015)

"No. It makes me think of medieval times. I hear peasant and all of those people that live in the poorest... I think peasant is kind of a derogatory term."

(farmer at farm 6, personal interview, 11 September 2015)

The last statement also revealed the widespread notion that the term peasant belongs to the past in this region of the United States.

"I think it is outdated now." (gardener at garden 1, personal interview, 14 May 2015)

"This terms feels very old to me, like Old England."

(farmer at farm 2, email interview, 11 June 2015)

For some of the interviewees, the word peasant implied an oppressed social class.

"Almost on the same step with slavery." (farmer at farm 2, email interview, 11 June 2015)

"That term isn't relevant in our society. It feels very hierarchal to me. To me, a peasant is a social class. [...] I don't feel limited in my social class nor do I feel I can or have to identify with my social class. It just doesn't feel relevant to me."

(wwoofer at farm 2, personal interview, 18 June 2015)

Two of the research participants supported the notion of peasants as poor and belonging to a different society, either from the past or a different part of the world.

Man farmer: "I don't think of anyone in the U.S. as a peasant farmer. That term to me seems like something from a Third-World country. Do we have peasants? I think the closest thing we have to a peasant would be the Amish. But they are the Amish. They are their own thing." Woman farmer: "We wouldn't call them peasants."

Man farmer: "I've never called anyone a peasant farmer before in my life. A peasant farmer to me is someone who farms on a very small, almost subsistence-like scale. In my mind I see somebody who is very poor in a material way, but not so in a spiritual or family way. Not as tied and locked into the whole capitalist financial system that I find myself completely bound in. And somebody who lived like that for a long time, for generations. Not like someone here like a homesteader, dropped out of a job and then started going back to the land or whatever. I almost think of the Russian peasant farmers or the Polish peasant farmers, these old women with their things on the back, making their sauerkraut and keep it all winter... They are really living on the land."

Woman farmer: "It feels like a really old word."

Man farmer: "We don't live in that world anymore. Even the Amish don't live in that world. All the bales you see around here wrapped in plastic, they all belong to an Amish man. Even 
they're tied into our world as much as they live separate from us."

(farmers at farm 3, personal interview, 30 June 2015)

This description of peasants is interesting, because it also points to the perceived independence of peasants from the dominant market economy. From that stance, they do not fit into the contemporary U.S. capitalist society that is perceived to be all-encompassing. These explanations also reveal positive connotations of the term, such as spiritual and social richness and independence.

The negative use of the word peasant implies a depreciation of the features it is associated with, such as subsistence, tradition and absence of money. Using the term in a positive way forces us to redefine our stance on these features, and in return, challenges the promised merits of modernity. In addition, the understanding that peasants are an oppressed social class leads to the question of what liberties rural people today actually enjoy or whether only the oppressors have changed from manorial lords to less tangible capitalists. There is no need to introduce a foreign substitute, such as campesino, to cover up these implications.

I suggest using the term peasant to describe farmworkers and landowning farmers, given La Via Campesina's inclusive definition, the large body of scientific scholarship, the fact that it is a common English term and the thought-provoking nature of the word. I will, however, refrain from representing the research participants as peasants out of respect of their rejection of this word. As less charged alternatives, I will use the expressions farmer, agriculturalist and agricultural producer when I write about all interviewees; or specific terms for specific people, such as gardener, farmworker or farmer.

\subsubsection{Farms and gardens and everything in between}

The word "farm" can describe different things. On the most basic level, it characterizes "an area of land and its buildings used for growing crops and rearing animals" (NEW OXFORD AMERICAN DICTIONARY, 2013). This understanding includes dissimilar facilities ranging from a small backyard garden to industrial feedlots and corporate enterprises that cultivate hundreds of square miles of monoculture cornfields.

In everyday use, however, a farm is frequently understood as an agricultural operation run with the intention to support the lives of the people that work the land. That could be anything from a small subsistence-oriented farm, a farm that is kept as a sideline or a commercial enterprise with several employees. Backyard and community gardens and often homesteads are usually excluded from this definition. This is problematic, because the yields of these undertakings still contribute to their cultivator's economy, if only to a smaller extent. The weakness of this separation is best exemplified by the concept of the hobby farm; an oxymoron by this understanding. The modifier "hobby" indicates that these farms are maintained for the enjoyment of their operators, not as a basis of a living. Despite that, they are called farms. ${ }^{3}$

Related to this concept is the notion that there is a minimum output for an agricultural operation to qualify as a farm. The gardener who participated in this study implied this idea by saying:

"We don't produce as much. Back when we were selling at the market I thought we were farmers but now I don't." (gardener at garden 1, personal interview, 14 May 2015)

What is more, in this statement, farming was also associated with a commercial orientation. From that point of view, an operation must sell products to qualify as a farm. This notion is shared by the U.S. Census of Agriculture, that defines a farm as "any place from which $\$ 1,000$ or more of agricultural products were produced and sold, or normally would have been sold, during the census year" (USDA 2012a). This classification leaves out any non-commercial agricultural undertakings, no mat-

The term hobby farm is difficult for another reason. It presumes a division between activities that someone does out of enjoyment and those performed for economic reasons. This distinction is not always made by farmers. 
ter how large they may be. It ignores production for self-consumption, even when the monetary equivalent exceeds the $\$ 1,000$ threshold.

The census is thus insufficient to describe the full scope of agriculture in the United States. This is problematic when claims are made about the assumed negligibility of non-monetary, subsistence or marginal farming. When the National Agricultural Statistics Service (NASS) decides not to count operations that do not sell any products, they make an a priori assumption about this insignificance with the consequence that this hypothesis cannot be tested due to this blind spot in the data.

As described in the previous chapter, gardens are often contrasted with farms. Gardens are perceived to be smaller and less commercially oriented than farms. Yet, there is not a clear distinction that separates the two as long the garden also produces food.

For the sake of an inclusive investigation of the various activities and scales that encompass agriculture, I second the basic definition cited in the introductory paragraph to this chapter as farms as "an area of land and its buildings used for growing crops and rearing animals" (NEW OXFORD AMERICAN DICTIONARY, 2013). It is in this sense, the term "farm" is used throughout this thesis.

\subsubsection{Family farms}

In common understanding, the ideal typical U.S.-American farm is a family farm. The institution of the family and the farm run deep in the North American psyche, and so the term is often freighted with sentiment and connotations of family farms as being small, sustainable and generally the ideal foundation of agriculture. As a result of these projections, the actual meaning becomes ambiguous.

The USDA Family Farm Report 2014 defines a family farm as "any farm where the majority of the business is owned by the operator and individuals related to the operator, including relatives who do not live in the operator's household" (HOPPE, 2014, 4). In this sense, $97 \%$ of the farms in the United States are family farms, ranging from smallest operations that just bypass the USDA farm definition threshold of $\$ 1,000$ in annual sales to some of the largest operations in the United States, with several thousand acres cultivated. Here, family farm is a social unit focusing on the ownership of the farm, irrespective of size or sales. What is more, the USDA extends their definition on individualowned operations without a family. Considering the relevance of the unity of family and farming for the production (cf. chapter 4.4 Approaching the peasantry), this definition is too blurry for a useful social analysis.

For CHAYANOV (1966), the family farm was the primary, indivisible unit of his theory of peasant economics. It denotes agrarian households that pooled most of their labor from the family. Chayanov equated the family farm with the peasant farm, because the family farm was the prevalent social institution on farms at his time. Regardless, many anthropologists have applied Chayanov's ideas to different agrarian settings, with different, if any, understandings of family. SPITTLER (1987) suggested that the family is not only a driver for decisions on farm production, but also a specific response to economic conditions.

All this suggests that the family is unsuited to define a peasant farm, or even a small farm. Instead, it is one of many social organizational forms of the peasantry.

\subsubsection{Farmers and farmworkers}

Now that the term farm is defined, it is important to differentiate between the various people who work on it. As long a farm is in operation, it has at least one farmer. Farmers own or lease the land as well as the buildings and machines themselves and are free to decide what to do with it. They bear the economic risk as well as the responsibility for the farm, the animals and the people on it. 
In the case of a family or a community farm, each member who works on it without receiving a fixed wage is a farmer. That is regardless of the way duties might be separated.

An operator is the person who legally controls the business. There can be more than one operator on a farm, when rights and titles are uniformly distributed.

There are also farmworkers who work for someone else. They do not own the land, but receive a fixed reward for their labor. The reward could be a wage for employed workers or a non-monetary gratification such as CSA-share, board and lodging for volunteers.

\subsubsection{Growth}

Growth is at the core of agriculture. The crops, the production methods, the social context and the economic end may all vary, but it is each agricultural producer's profession to grow plants or livestock. The gardener, for example, linked the concept of growing to plants:

"Plants desire to grow. I desire them to grow." (gardener at garden 1, personal interview, 14 May 2015)

This material understanding of growth describes the tangible increase of matter of a subject as a transformation. In this concept, growth is intrinsically connected to a cycle with decay and a constant material basis. As long as an entity is able to metabolize, that is, transform exogenous (originating from outside) to endogenous (belonging to the entity) matter, it grows. When it loses its capability to metabolize, it starts to decay, reversing the transformation. Material growth and decay build on each other.

From this perspective, growth is both limited and limitless. An individual can only grow to the point where its material basis is fully absorbed or where it dies. Growth as a universal concept, however, is re-triggered through decay and, thus, limitless as long there is energy to fuel the metabolism.

From an economic perspective, agriculture is the practice of utilizing material growth for human needs. It directs growth from weeds to crops, from wildlife to livestock and from perceived chaos to ornamental gardens that please human beings.

The immaterial understanding of growth, on the other hand, describes the intangible increase of attributes of an idea as a formation or transformation of immatter. The extent to which ideas are rooted in a material basis range from no material basis at all to a strong connection. (Materialist philosophers would argue that everything has nothing but a material basis, but we will follow the argument of dualist philosophy of mind).

"We grow in many ways, spiritual is most important." (farmer at farm 2, email interview, 11 June 2015)

This statement by one of the interviewed farmers is an example of immaterial growth without a material basis, which is difficult to describe, as it is intangible by definition. Dualist Philosophers such as Descartes associate the realm of immatter with the human spirit. Hence, immaterial growth without material basis may be called spiritual growth.

Whether a certain attribute of an idea can grow infinitely depends on its ability to form or absorb immatter. Due to its immateriality, this cannot be empirically explored. Thus, the limits to spiritual growth are a question of belief.

The third type is immaterial growth with a material basis, or abstracted growth. Here, the change of an object in the material world is observed and translated to an attribute of an idea by some kind of theory. In this understanding, it is the attribute that increases, not the material object itself, which may grow, shrink or remain stagnant. 
Asked whether he wanted his farm to grow, the operator of farm 2 replied:

"Yes, we want to grow but also to shrink in size. To be more efficient and focused and not expand our acreage anymore." (farmer at farm 2, email interview, 11 June 2015)

Regardless of the farmer's attitude towards growth, he relates it to efficiency and acreage.

In fact, a farm is a good example. A farm is immaterial, an idea, a social organization of soil, people, plants, perhaps livestock, buildings, tools and machines. Each of these elements is material, the farm as an organization, however, is not. When people refer to farm growth, usually they mean acreage, sometimes net worth. Here, the farm is the idea and its size or net worth the attributes.

A farmer might acquire land and call this an increase in farm size. However, it is not the land itself that increases but the amount of land she or he is legally allowed to cultivate. It is the social theory of private land ownership, or generally private property, which translates a piece of land to farm growth. Yet, farm size is still tied to the physical land and as such limited to the available arable land.

The connection between net worth and the material world is weaker. It is still linked to material elements of the farm, but the theory is less straightforward. In this example, the different parts of the farm are not merely counted, but appraised in a complex socio-mathematical system, factoring in perceived supply and demand, subsidies and other intangibles. It is possible (and common) for a dairy farm to decrease in net worth despite producing more milk due to declining milk prices. When this happens, the concept of farm growth is fully decoupled from material milk growth and shifts towards the spiritual.

In the usage of the word growth, the differences between a subsistence culture and the capitalistic maximization culture can be clearly observed. When the term is used in its material sense, the material world, that is, the foundation of life, is at the center of attention. It is this focus on life and the conditions of its reproduction that BENNHOLDT-THOMSEN and MIES (1999) have described as the subsistence perspective. From a capitalistic perspective, the subject of interest is the accumulation of capital, which is an abstract entity. Thus, growth in this context is perceived abstractly. It is an indicator of the "war on subsistence" (ILLICH, 1982) on the discourse level that the abstract sense is increasingly becoming the default understanding of growth. In mainstream economics, it appears it has already reached hegemony.

To sum up, there are three distinct types of growth: material, spiritual and abstracted. The research participants in this study used each of them depending on the context. In many instances, it was obvious which kind of growth someone referred to, but confusion arises when abstracted or spiritual growth implies material growth and vice versa. The distinction between these three types is meant to refine the discussion about growth and to clear up some of this confusion.

\subsection{Subsistence perspective}

The subsistence perspective developed by Veronika BENNHOLDT-THOMSEN and Maria MIES (1999) puts the production of subsistence at the center of socioscientific analysis and frames it positively as a universal prerequisite of fulfilled human life.

Subsistence is everything that is necessary for a good life. It includes the material basis such as food and shelter (material subsistence), the things one derives direct pleasure from (cultural subsistence), and attention and sympathy to satisfy social needs, such as love and nurture (social subsistence).

Focusing on subsistence is both unifying and separative. It is an egalitarian approach that puts the subsistence needs of the very poor and the very rich on the same level. MASLOW (1943) pointed to universal needs for a fulfilled life-physiological needs, safety needs, love and belonging, esteem and self-actualization-which may be summarized as subsistence. To satisfy these needs, subsist- 
ence production will always be necessary. It is the indispensable undercurrent that connects the different forms of social and economic organization that have existed throughout history.

At the same time, this focus separates cultures that are centered on the reproduction of subsistence and life from those who exploit it for other ends, of which capitalism is the most dominant today.

"Subsistence production or production of life includes all work that is expended in the creation, re-creation and maintenance of immediate life and which has no other purpose. Subsistence production stands in contrast to commodity and surplus value production. For subsistence production the aim is 'life', for commodity production it is 'money', which 'produces' ever more money, or the accumulation of capital. For this mode of production life is only, so to speak a coincidental side effect." (BENNHOLDT-THOMSEN and MIES, 1999)

Different cultures also lead to different forms of subsistence production. While keeping a small flock of sheep on dry land and a kitchen garden at home and making money on Wall Street to shop for food and entertainment at the mall are both common ways to organize one's subsistence, they are decisively different. Unlike the latter example, the former produces subsistence directly, without the detour via the trade of commodities. Even more importantly, there are significant qualitative differences. Being able to provide for oneself or the community strengthens ones autonomy, pride and creativity, which are surrendered to companies and entrepreneurs when subsistence is secured through commodities. Modern economics reduces need satisfaction to the quantifiable consumption of goods, ignoring the social dimension of production and trade (BENNHOLDT-THOMSEN, 2006). The primacy of modern economics had led to the unidimensional view of economy that attempts to account for everything in monetary terms. Activities, products and services that have previously been produced without being counted are either quantified (often by force and by changing important social characteristics such as ownership and control, for instance through privatization and enclose of commons) or made invisible. Take childcare as an example. Childcare today is either provided by professionals as a commodity or by relatives. Only the former is regarded an economic activity that figures in the gross domestic product (GDP), while the other is respected at best as an important service to society, but not seen as economic. From that perspective, it is logical that the commodification of childcare is seen as progress, because it increases the GDP, the modern unit for development. The irony of it is that childcare has been provided for millennia and it has always been hard work. Only the act of turning it into a commodity made it figure in the GDP and appear like some sort of growth, while the same process stripped it from its associated social dimensions and, thus, from some of its most important qualities.

By focusing on the production of subsistence as the foundation of any economy and something from which pride and autonomy derives, the subsistence approach appreciates the work of many women, peasants and other subsistence producers that rarely figure into economic statistics.

The subsistence perspective can be applied in any social analysis. Despite contrasting subsistence production with surplus value production, it does not depict the former as pre-capitalist, but as something that exists within and next to it. To name just two examples, commercial farmers grow vegetables and herbs for their families and women prepare dinners and care for their children despite being exhausted from their day jobs.

The coexistence of commodity and subsistence production is everything but peaceful, however. Ivan ILLICH (1982) described a "war on subsistence," that has systematically limited the scope of subsistence production since the rise of today's capitalism since 1945, even though this trend started much earlier. The enclosure of commons forced peasants to engage in commodity production or wage labor for money to buy land. Many century-old subsistence techniques such as on-farm slaughtering, seed saving or childbirth at home have been controlled, limited or even outlawed by the state. This claim on control over subsistence supports the notion of capitalism as a system of rule, not just economy, because "[o]nly after people's capacity to subsist is destroyed, are they totally and unconditionally in the power of capital" (BENNHOLDT-THOMSEN and MIES, 1999, 19).

The subsistence perspective cannot be fully comprehended without an understanding of the developmentalist discourse that sought to subordinate subsistence by first marginalizing and then colo- 
nizing it. Starting after World War II, the former colonial empires of the Global North used their hegemony to impose their own development model on the countries of the South. The very distinction between "developed" and "developing" countries signifies that position. The international development organizations tied foreign aid to expectations for receiving countries to commodify their production and open their economies to the world market. To justify this policy, subsistence production was framed as a non-economic activity. Since development was measured by the GDP in which only the exchange of commodities figures, but never non-monetarized subsistence activities, the contributions of subsistence producers to the quality of life were disregarded (cf. BENNHOLDTTHOMSEN, 2006). It so happened that subsistence production was associated with underdevelopment and poverty. By the same token, and building on a long-established colonial supremacism, subsistence production has been attributed to the "poor" and "underdeveloped" Global South and ignored or made invisible in the North to justify the latter's perceived superiority.

Regardless, the universal human dependence on subsistence is the cause for the persistence of subsistence production despite industrialization or proletarianization of peasants, even though these trends force it to "change its character" (BENNHOLDT-THOMSEN, 1981). Under these pressures, subsistence production becomes more industrial itself: more commercial, commodified, anonymous, of lower quality and less appreciated (BENNHOLDT-THOMSEN, 2006).

The use of the word subsistence for this framework is both a curse and a blessing. It is a curse because it often provokes dismissive reactions. In common usage, the term is often connected with poverty, for example by the operator of farm 5 :

"It could be my own prejudice, but I feel there is a certain level of poverty associated with that term..." (operator at farm 5, personal interview, 17 September 2015)

Mies and Bennholdt-Thomsen see a difference in the understanding of the word, depending on one's stance:

"For the men and women who profit from the war against subsistence, 'subsistence' spells backwardness, poverty, and drudgery. For the victims of this war it means security, the 'good life', freedom, autonomy, self-determination, preservation of the economic and ecological base, and cultural and biological diversity." (BENNHOLDT-THOMSEN and MIES, 1999, 20)

The distinction between beneficiary and loser is blurry, however. People in industrialized countries both profit and suffer from the war of subsistence. Farmers are a prime example of that. Many have indeed benefited from the discontinuation of small subsistence farms, from subsidies that support commodity production in the Global North at the expense of smallholders in the South or from access to middle-class consumer goods. Yet they are increasingly forced to submit to the rules of the market or the state, they are under constant pressure to sell and their communities deteriorate as less and less people are able to make a living off the land and move to the cities. Thus, Western farmers hold a differentiated view on subsistence. The research participants in this study did not express negative views on subsistence farming. They mostly associated it with self-provisioning and independence from a money-based economy, which many regard as impossible in today's United States.

"I think of a subsistence farmer as someone who either produces all his food or only produces food for himself and no one else." (wwoofer at farm 2, personal interview, 17 June 2015)

"I like that term, but I do not consider myself a subsistence farmer. It is not possible today. You have to sell things." (farmer at farm 2, email interview, 11 June 2015)

"To me that means that I would have a parcel of land and work the land and live off the land, totally sustainably. That would be the ideal. Using sustainable energy as well as gardening or farming sustainably." (wwoofer at garden 1, personal interview, 7 July 2015)

"I think that term you don't hear much in the United States. I guess I also don't identify with it because we have off-farm jobs." (operator at farm 5, personal interview, 17 September 2015) 
For the operator at farm 3, subsistence production and money are not mutually exclusive, yet his commodity production has nothing to do with subsistence.

"A subsistence farmer to me would be somebody who's just making all their food themselves, living very simply, not have all this capital crap that I have got here... I picture that as maybe selling a little bit of what you grow to get the money to buy the things you can't make yourself.... We still derive most of our stuff that we eat from somewhere else and we are producing commodities that are sold for cash to supply the farm where a subsistence farmer is not... maybe doing some trading, too, I don't know. But completely different from what we do." (operator at farm 3, personal interview, 30 June 2015)

The blessing of the term is that its contestation is an analogy to the war of subsistence. Understanding the cultural prejudices about the word subsistence helps to make sense of political or economic action against the autonomy of women, peasants and other subsistence producers. In return, reclaiming the term subsistence as the goal of all production may lead to a more sustainable and less exploitive understanding and practice of economy.

\subsection{Co-sufficiency and subsistence markets}

The subsistence economy requires cooperation and community to function. BENNHOLDTTHOMSEN (2006) suggests that "[t]he basis of the subsistence economy is self-provisioning. But self-provisioning should not be understood in the sense of the isolated, egocentric individual. [...]" She further points out that subsistence production can be the starting point for a community of reciprocity. Only one who is able to produce something has something to offer, to share.

Mark BOYLE (2012) uses the term co-sufficiency to denote self-provisioning in community. He contrasts this concept with self-sufficiency, "because self-sufficiency is an illusion. At the very least we are interdependent with bees, bacteria and earthworms, and in all reality on people from our local community, whether that be your street, village or an intentional community."

Co-sufficiency requires individuals of a community to meet in order to balance their supply and demand of goods and services for their subsistence. BENNHOLDT-THOMSEN and MIES (1999, 115ff) describe these processes as "subsistence markets."

" 'Subsistence markets' and 'subsistence trade' are for us processes of exchange in which the link persists between subsistence and market; that is, in which useful and necessary supplies mainly food, but also clothing, household equipment, building material, furniture, et cetera - are traded as use-values. " (BENNHOLDT-THOMSEN and MIES, 1999, 115)

Subsistence markets are networks of exchange relations that have historically existed and continue to exist along the capitalist market. They challenge the widespread belief that subsistence equals self-sufficiency in isolation. On the contrary, the intension of these markets is mutual provisioning with the material prerequisites of subsistence and the building of community instead of maximizing profits. Often, producers trade themselves or intermediaries are so closely linked to the producers that they feel personally responsible for the product. As a result, the quality of a product is guaranteed through a system of accountability and reputation.

Like any market, the subsistence market is an expression as well as a condition for the society it belongs to. Analogues to the definition of subsistence production (cf. chapter 4.2 Subsistence perspective), subsistence markets include all trades that are performed in the creation, re-creation and maintenance of immediate life and that have no other purpose. Subsistence markets stand in contrast to commodity markets. For subsistence markets the aim is "life" and for commodity markets, it is "money" that "produces" ever more money, or the accumulation of capital. 
The determining qualities of subsistence markets are the values on which they are built; mutual provisioning, immediate reproduction of the good life and the building of community. Whether or not money is involved as a medium of exchange is an organizational question, not a defining factor.

\subsection{Approaching the peasantry}

The difficulty in finding the right terms for various agricultural producers (cf. chapter 4.1.1 One word for "all people of the land") hints at the diversity and inconsistency of farming itself. There is great variation in the social organization of agriculture both on the micro and the macro level. Academics have tried to describe, label and analyze the different organization systems that have existed throughout history. This chapter gives an overview of representations of contemporary farming systems with an emphasis on peasant farming.

While many scholars have tried to make sense of the seemingly implausible persistence of the peasantry in the face of ongoing industrialization and capitalization, CHAYANOV (1966) was the first to stress the impossibility of understanding the diversity of agricultural production from the perspective of one particular mode of farming: capitalist ${ }^{4}$ farming. Not only did he point out that the peasant farm is inherently different from a capitalistic operation, but, according to Chayanov, the dissimilarities are so significant that the model used to analyze behavior of capitalistic enterprises that is neoclassical ${ }^{5}$ economics, cannot be applied to the peasant farm. The decisive differences are that peasant family farms do not pay wages for their labor, own their means of production, and thus, do not need to make a profit for any creditors. On that account, the neoclassical thinking that seeks to understand and optimize these parameters does not explain the economy of the peasant farm (cf. THORNER, 1966). Therefore, he developed a "theory of peasant economy" that established the framework and much of the vocabulary for the emerging field of Peasant Studies.

Chayanov puts two balances in the center of his theory. The first one is the balance between drudgery and utility. Chayanov observed that peasants in Russia had well-defined needs and sought to meet those with the least amount of work. Once they were met, they had no reason to produce more. The second balance is that of consumption and labor. In short, the more people live on a farm who do not participate in the daily chores, the harder the others have to work. This is typical for large families with many children and retired farmers still alive. Peasant farmers usually intensify their production after the birth of a child and extensify as family members die or move out.

Chayanov explained the persistence of the peasantry with its ability to operate outside the ups and downs of commodity markets. For instance, peasants are able to mobilize extra labor by working longer hours without paying overtime. Low sale prices may demand a lot of hard work, but unlike corporate operations, peasant farms cannot go bankrupt since they do not need to generate a profit to service their loans, which puts them at a comparative advantage (cf. THORNER, 1966, xviii). In his introduction to the German translation of Chayanov's "The Theory of Peasant Economy," SPITTLER (1987, XXIV) added that peasant farms are able to survive in times of economic hardship because they produce food. This is in contrast to family craft enterprises that also control their means of production, but which are bound to make a profit to buy food for their consumption.

While Chayanov's work was mainly focused on the peasantry, he was aware and critical of profitoriented capitalist farming enterprises, even though those were few compared to the number of peasant farms during his time. He was also skeptical about the Marxist approach to agrarian change,

\footnotetext{
${ }^{4}$ The way capitalism was discussed during Chayanov's time differs widely from today. In the early 20th century, the focus was on capitalism as a system that exploited workers for the benefit of capitalists. In the second half of the century, and particularly after the collapse of the Soviet Union, the attention moved to the notion of neoliberal capitalism as a global, hegemonic system that affects economies and culture on every level at every place. Put differently, in the first half of the 20th century, capitalism was still one economic system out of many, whereas in the second half of the century, capitalism is everywhere, even though pockets of resistance exist.

By neoclassical I mean the idea to optimize production through marginal utility calculations on isolated parameters, such as profit, output or resource exploitation. This thinking is at the core of industrial production that is the main mode of production in both capitalism and Leninism.
} 
which treated farmers as proletarians and producers of commodities, ironically similar to the capitalist view.

The establishment of the subsistence perspective was in part a reaction to the dominant development discourse that sought to commodify agricultural production and to push peasants off the land (see chapter 4.2 Subsistence perspective). BENNHOLDT-THOMSEN and MIES (1999, 86ff) see subsistence-orientation at the heart of the peasant economy and used the latter as empirical evidence to build their theory. For them, peasants are characterized by a certain culture and worldview, which includes subsistence-orientation, sustainability, reciprocity, a "live and let live" mentality, and risk avoidance. This way of understanding the peasantry is more encompassing than Chayanov's theory because it goes beyond the singularities of the Russian early 20th-century society, which was predominately made up by family farms.

Much in the line of Chayanov's thought (even though surprisingly rarely cited), the Viennese tradition of landscape planning divides the agricultural sector in two contrasting parts: peasant agriculture and industrial agriculture (cf. SCHMIDTHALER, 1997, 17; GEHLKEN, 1995, 262ff). Based on the subsistence perspective as outlined above, the Viennese approach defines peasant farming as the production of food with the purpose of self-provisioning, or as agrarian subsistence production. SCHNEIDER (2007, 117 [author's translation]) considers the "social vicissitudes of life", that is biographical changes, not monetary maximization as the primary determinant of farm production. The expense of labor is limited to the satisfaction of personal needs, which themselves are finite. Since peasants control the means for their reproduction (land, labor, seeds, knowledge, livestock) and use free natural productive forces (LÜHRS, 1994, 29), they are relatively independent from external capital. On the output side, they strengthen their independence from sales markets by providing a diverse range of products. The operation of the peasant farm is geared simultaneously towards the production of food and the reproduction of its means of production; for example, the fertility of the soil, the well-being of the family (labor) and the health of the livestock, which makes a respectful relationship to nature imperative. GEHLKEN (1995) calls this conservation through use. The unity of production and reproduction as equally important parts of the peasant economy leads to a comparable appreciation of the work of women and men, even when gender-based division of labor exists.

Peasant agriculture is contrasted with industrial agriculture, whose primary goal is the production of commodities for sale to generate a profit. Through this orientation, industrial farms enter a close relationship with their sales markets, which dictate prices through a system of competition. In order to sell, farms have to streamline their operation, meaning they specialize and intensify their production. Since other farms are doing the same, prices drop, which retriggers and amplifies this process of so-called rationalization. In order to finance the necessary investments in equipment, fertilizer, pesticides and improvement of land, farmers have to take out loans, making them subject to external capital on top of their dependency from sales markets. The reliance on chemicals and technology in industrial farming replaces traditional knowledge with natural scientific academic expertise (chemistry, biology) and machinery, shifting the locus of agricultural innovation from the fields to universities and companies and, as a consequence, delimiting their autonomy. In short, industrial agriculture is a trajectory of increasing dependence of farms from off-farm players. What is more, the focus on commodity production lessens the importance and pride of subsistence production on the farm, most often the sphere of women, who then turn into rural housewives (SCHMIDTHALER, 1997, 21).

While this framework provides an accurate description of two common types of agricultural production, it falls short in explaining the relationship between the two. As a result, the existence and the struggles of the many farmers between these two extremes remain inexplicable. A social theory is needed to understand and influence the development of these types.

To offer a way out of the scientifically constructed dualism between peasant and industrial farming VAN DER PLOEG (2008) proposed the perhaps most comprehensive theory to interpret the plethora of modes of contemporary farming. To begin with, he distinguishes between three ideal typical modes of agriculture, or constellations, as he calls them: corporate agriculture, entrepreneurial agriculture and peasant agriculture. 
Corporate agriculture denotes modes of farming that are based on financial investments of external capital, fully geared towards the maximization of surplus value and financial profit. The labor force of these operations consists mainly of salaried workers. Van der Ploeg uses the term capitalist agriculture synonymously with corporate agriculture, but does not explain why he restricts capitalist production to this constellation, even though other modes of agriculture are equally subject to capitalist pressures.

Entrepreneurial agriculture is expansion oriented on an existing agricultural basis. Its aim is to gain control over the resources of other farmers and to add value to its products. Its production is entirely directed towards sales, which integrates these farms in commodity markets. The reliance on financial and industrial capital deepens their dependency. In contrast to corporate farming, labor is mainly provided by family instead of hired, that is labor is not commodified (cf. also VAN DER PLOEG 2013). Entrepreneurial, just like corporate agriculture, is what scientists and policy makers have in mind when they conceive farmers as homines economici, that is, as self-interested and accumulationoriented market participants whose behavior is predetermined by a neoclassical rationale.

Peasant agriculture is production oriented towards subsistence. Increasing autonomy and reproducing and improving one's own livelihood on the land are the overall purposes of production. The farm owns their means of production and pools labor from the family and the community through a system of reciprocity. Influenced by Chayanov, van der Ploeg reiterates that peasants are misunderstood when analyzed through a neoclassical lens.

The merit of van der Ploeg's work lies in his theory of the connections and interrelations between these three constellations. It offers a way to comprehend the reality of the majority of farmers who do not fully match any of these ideal types.

First, his framework builds on the assumption that the three constellations of agriculture represent both ideal types and specific conditions. Depending on the particularities of a farm, each of these conditions may affect farmers who have to adjust their operation accordingly. For instance, both the peasant condition and the entrepreneurial condition may have an impact on a farm that has to find a balance between market integration and distancing. Van der Ploeg coined the expression degrees of peasantness to describe the extent to which farmers are embedded in the peasant condition.

Second, there are several transitions from one constellation to the other. Peasant farmers may become more corporate, while entrepreneurial farmers become more peasant-like, et cetera. Van der Ploeg does not elaborate on each of these transitions one by one, but argues that there are three main trajectories in our time: industrialization, repeasantization and deactivation. Industrialization denotes the flows towards more industrial, corporate farming. It may appear in the industrialization of peasant farmers, entrepreneurial farmers and the even further industrialization of corporate operations. Its counter-development is repeasantization, that is, the transition towards more peasant farming. It is not limited to people who already farm. Likewise, the influx from previously not farming workers into agriculture is a form of repeasantization. The third current described by van der Ploeg is deactivation. It signifies the abandoning of agricultural activity, which affects farmers of all constellations. He also touches the trend of depeasantization, which essentially consists of processes of industrialization and deactivation.

Van der Ploeg avoids giving a definition of peasantry. Instead, he discusses the peasant condition, which describes peasants.

"Central to the peasant condition [...] is the struggle for autonomy that takes place in a context characterized by dependency relations, marginalization, and deprivation. It aims at and materializes as the creation and development of a self-controlled and self-managed resource base, which in turn allows for those forms of co-production of man and living nature that interact with the market, allow for survival and for future prospects and feed back into and strengthen the resources base, improve the process of co-production, enlarge autonomy, and, thus, reduce dependency. Depending upon the particularities of the prevailing socioeconomic conjuncture, both survival and the development of one's own resource base might 
be strengthened through engagement in other non-agrarian activities. Finally, patterns of cooperation are present which regulate and strengthen those interrelations."

(VAN DER PLOEG 2008, 23)

The peasant condition, then, is a set of circumstances and actions in which peasants operate. While encompassing the reality of all peasants, it allows for enough individual responses to explain the many dissimilarities within the peasantry around the world. Co-production, the striving for autonomy and development through one's own labor are fundamental elements of the peasant condition.

Van der Ploeg further describes what he means by the flowery "co-production of man and living nature." It is the simultaneous production of consumer goods and services (for sale or self-use) and the reproduction of the farm's own resource base, as well as the co-production of social and natural resources. From this, it follows that peasant agriculture relies on diversity to ensure the sustainability of its production, or more pointed, the survival of the farm.

The striving for autonomy is another key part of the peasant condition. The way peasants try to achieve autonomy is manifold, but two major elements are the distancing from commodity markets and the abovementioned reproduction of a (self-controlled) resource base. In fact, van der Ploeg denominates the development of the resources base through labor as the central arena of social struggle towards the emancipation of the peasantry.

Generally, the labor process is a field that distinguishes the peasant condition from other modes of farming. It is a strong belief within the peasant culture that one's own hard work creates autonomy and progress. It is through working in the field that knowledge is acquired and carried on. Increasing needs are usually met by labor-driven intensification. From this it follows that peasant farming tends to be more labor intensive than other modes of farming.

Pluriactivity and cooperation are additional features that van der Ploeg regards as common of the peasant condition. Pluriactivity is the combination of on-farm and off-farm work. Peasants invest the rewards of the latter in the resource base of the farm to increase autonomy. It is an alternative to credit to obtain funding (for which many peasants do not qualify to begin with). The main advantage of money earned from off-farm work is that it enters the farm economy unconditionally. There are no further obligations to work for loan payments and to produce a surplus to meet the interests. Inputs purchased from money earned enter the farm as use values and do not need to be monetized or even quantified.

Cooperation is another common feature of peasantry according to van der Ploeg. It presumes that the goals of peasants are best achieved collectively. This may be one explanation of the prevalence of family farms, which are in and of themselves cooperative units of production. Regardless, cooperation is a process that goes beyond the discrete unit of production as different farms collaborate in various ways with each other. Hence, cooperation is a principle that transcends and connects the peasantry from the individual farmer via the farm to the entire community.

According to van der Ploeg, the peasantry is not defined by a consistent group of people, but by a set of values, behavior and circumstances that describe the peasant condition, which affects and is shaped by farmers to different degrees (of peasantness). The peasantry is not an inheritable social rank, but a dynamic culture that is constantly and actively reshaped by its constituents. The qualitative (farmers acting more peasant-like as before) and quantitative (more people engage in peasant farming as before) increases of peasantness are called repeasantization. While this framing of the peasantry is unsuited to devise a quantitative representation of what the agricultural sector looks like in a specific place at a given time, it gives a valuable orientation of the dynamics and contradictions that shape agriculture and provides a framework to anticipate its future development. 


\subsection{Intrinsic and extrinsic conditions of farming}

Chapter 5 (Farming in the Central Finger Lakes) describes the contradictory reality of farmers in the Ithaca Local Market Area. Intrinsic and extrinsic conditions impact the production of the farm, and farmers constantly have to negotiate between the two. The intrinsic condition designates the demands that result from the farmers' reproductive needs, values and goals in life. The extrinsic condition, in contrast, comprises the effective demands that off-farm actors put on the farm. These are driven by some form of power that forces farmers to react to them.

This model is different from distinguishing between on-farm and off-farm factors because it focuses on the needs of the farmers as human subjects rather than the farm as an institution. By way of illustration, when farmers around Ithaca invest their time in organizing potluck dinners, they cater for a need of the community, an off-farm demand. Yet, it is an intrinsic activity because it helps foster a supportive community that benefits the farmers.

While farmers may try to shape their production according to their intrinsic interests, they also have to react to pressures imposed on them. Farmers need suitable means of production, e.g., land, seeds, knowledge, machines, labor, et cetera, in order to farm. However, in the United States, the access to these means of production is largely controlled by the capitalist state. ${ }^{6}$ It is through this dependency relation that farmers have to either abide by the rules by the state or struggle for autonomy by seizing the means of their production. Whichever strategy they choose-often a combination of the two-it is critical to realize that these demands are extrinsic and imposed on farmers by force.

A good example to illustrate this force is the access to land, which is mainly organized as private property. When someone wants to start farming, they either have to buy or lease land, and then pay a mortgage to a creditor or rent to the landlord. If they fail to make these payments, they will eventually be evicted by the police. The same may happen when land is used without the consent of the landowner.

To use another example, selling commodities to service loan payments is, contrary to common belief, not an economic necessity for the reproduction of the farm. It is a burden imposed by a third party, an appropriation of surplus value through the exploitation of an imbalance of power. Of course, there are trades of commodities that are economically necessary, if they allow someone else to provide something one needs; for instance, paying someone to perform labor or a service. However, paying beyond the use-value for that person to accumulate capital is a social arrangement, not an economic necessity. Thus, this exploitive arrangement is an extrinsic condition to farming.

To be sure, not always do these rules run counter to the needs of farmers and a lot of them are necessary to guarantee the functioning of society. However, the distinction remains that some farm activities are driven by the farmer's own interest, and others are carried out on account of external pressures.

The relationship between intrinsic and extrinsic conditions can be described as a struggle. Farm production is a result of both, but in order to life a live as close to their own values as possible, farmers try to distance themselves from the extrinsic condition as much as possible. VAN DER PLOEG (2008) sees this struggle for autonomy as a core element of the peasant condition and conceptualizes it as a kind of farmer's resistance. On the other hand, the institutions of the capitalist state pull towards the opposite direction by imposing ever more regulations that restrict farmers in their selfdetermination and increasing the prices for the means of production to increase dependency.

In summary, internal and external conditions, in other words, conditions that originate from the economic necessities of reproduction, as well as the values and goals of the farmers and conditions from external forces such as the state and capital, shape the production of a farm. Farmers struggle to direct as much of their endeavors towards the former.

Understood as a system of social order, legal institutions and concentrated capital. 


\section{Farming in the Central Finger Lakes}

\section{1 "I love vegetables": Motivations to farm}

A driving motive behind this thesis was the question why farmers and their workers decided to live off the land, despite economic difficulties and growing disdain of their chosen profession.

To start with, the love for good food was mentioned as an important reason to farm throughout the interviews. Five of the interviewees referred to it explicitly:

"I want to eat food that is as fresh as possible, still warm from the sun." (gardener at garden 1, personal interview, 14 May 2015)

"I love vegetables. That's why I started my farm. I try to avoid the grocery store as much as I can." (farmer at farm 4, personal interview, 1 July 2015)

"The biggest motivation starting out was that I love vegetables. I love to cook, I love to eat them. I think if I didn't love vegetables I don't think I would have as much of an interest in farming. I don't really like to grow things that I can't eat as much."

(farmer at farm 5, personal interview, 10 July 2015)

In the same sense, one of the workers at farm 4 stated that, to make sure he could eat the best and freshest produce, he developed an interest in growing vegetables himself and becoming a farmer. Besides producing healthy food for themselves, some farmers took pride in providing their customers with high-quality foodstuffs.

"I do like the organic part of the farm, that we are giving people the best, cleanest food that is out there. We know it doesn't have any residual antibiotics or pesticides in it, no carcinogens or neurotoxins so I like that part."

(farmer at farm 6, personal interview, 11 September 2015)

"Probably the most rewarding part is when people come to the store and say how good, I mean we don't have beef to eat but this is our beef and my brother's produce and they say this is the best produce, the best meat they've ever had, they buy raw milk from me." (farmer at farm 6, personal interview, 11 September 2015)

In addition, working outside had an equally common appeal of farming among the research participants.

"There is so much about farming that I enjoy. I love to be outside."

(farmer at farm 5, personal interview, 10 July 2015)

"Once I realized how much I hated working in an office and sitting around all day, I remembered [the week-long experience I had on a CSA-farm]. A friend told me about wwoofing. So I looked it up and it blew my mind and I thought this is perfect."

(wwoofer at garden 1, personal interview, 7 July 2015)

The interviewee at farm 6 decided to go back to the farm, while working a day job at Cornell:

"At that job I was in an office, sitting inside all the time."

(farmer at farm 6, personal interview, 11 September 2015) 
Another common reason for some of the interviewees to work on farms was that no occupation other than farming appealed to them.

"I couldn't have any other job. I went to college for a semester, because this is what you are told to do. I dropped out, though, because I didn't like it. All I want to do is farming. " (farmworker at farm 4, private conversation, 5 August 2015)

"I am frustrated by other forms of work. I like to be outside and feel useful to others." (farmer at farm 2, email interview, 11 June 2015)

"I could be sitting in an office 40 hours a week and it would be so easy. I could go on vacation in the summer. But realistically, I know this is not the life I want to live."

(farmer at farm 5, personal interview, 10 July 2015)

"I didn't have anything pulling me in another direction."

(farmer at farm 6, personal interview, 11 September 2015)

Furthermore, three of the interviewees referred to the merits of their agrarian lifestyle, or the "good life" as what kept them motivated.

"It's a good life, really." (farmer at farm 6, personal interview, 11 September 2015)

"I just really love the life we have built doing it. [...] Sometimes I wonder what people even do with all their spare time if they don't have a farm?"

(farmer at farm 5, personal interview, 10 July 2015)

The gardener linked the good life and her work with a longing for beauty:

"I think it is a quest for beauty. I want to be in a beautiful place and I want to eat food that is as fresh as possible, still warm from the sun. Which I guess is what I think is the good life. Just trying to live as good as possible."

(gardener at garden 1, personal interview, 14 May 2015)

"My primary reason is grand about living a beautiful life, in a place that is visually beautiful. Inside and out, I want it to be beautiful and having fresh food is a part of that."

(gardener at garden 1, personal interview, 14 May 2015)

Additionally, the pride in feeding others was also mentioned as a motivation to run a farm. Two interviewees referred to providing food to a broad, undefined set of consumers.

"There are so many aspects on a farm. Making people happy, providing for people." (wwoofer at garden 1, personal interview, 7 July 2015)

"I do like the organic part of the farm that we are giving people the best, cleanest food that is out there." (farmer at farm 6, personal interview, 11 September 2015)

The operator at farm 3 specified that supporting his family was a major motivation for him.

"I just never wanted it to be something I'm doing on the side or just for the fun. It lacks significance to me if it isn't something I am doing for real or doing to support my family."

(farmer at farm 3, personal interview, 30 June 2015)

Similarly, the gardener stressed her motivation to provide healthy food to her children, linking her work in the garden with motherhood.

"The children. Now being a mother, it is even more important that I encourage that growth. [...] It concerns me, hormones in animal products and how that affects my children's development. My daughter in particular since she is female. 
Being a mother, the desire to know the origins of my food becomes stronger." (gardener at garden 1, personal interview, 14 May 2015)

Yet another reason why interviewees became interested in farming was someone else's example or first-hand experience.

The gardener was intrigued in organic food and its production by a long-time friend of hers:

"I think it was post college. There was a girl that was working on a farm in Rochester. I've known her for a long time, probably my oldest friend. She talked about organic food. I've never even heard of such a thing. She turned me on to spend more attention to what I eat. I think that was it." (wwoofer at farm 2, personal interview, 18 June 2015)

The operator at farm 3, on the other hand, made his first encounter with farming at his uncle's farm, which made a deep impression on him:

"Going to my uncle's place. I don't know what it was about it. There was just something about the sights and smells and the whole atmosphere. I was just fascinated with it from the first time I saw it. There was just something about it that just drew me in."

(farmer at farm 3, personal interview, 30 June 2015)

This initial interest intensified when he visited a large, commercial farm that belonged to the family of friends of his.

"Then, fortunately for me, my best friends growing up had moved to the town I was in from Ohio. And their family had a big farm out in Ohio. In the summers I would often go with them to their family farm. That was a much more big, commercial adventure than my uncle's farm, which was just a hill farm up in the hills of Pennsylvania. They had like 30 cows. It was a small farm. When I saw that, I was like 'Oh man, this is cool. I've gotta do this. That kinda set me on the track." (farmer at farm 3, personal interview, 30 June 2015)

The operators at farm 5, coming from a professional background in media, became interested in farming through their experience as farm volunteers.

"[...] the experience of wwoofing [...] contributing to us starting the homestead and what would eventually become the farm." (farmer at farm 5, personal interview, 10 July 2015)

The wwoofers who were interviewed also referred to short-term farm experiences that set them on track to learn more about farming and volunteer through the WWOOF network.

"I took the Permaculture Design Course in the winter of my junior year at college. That was almost a spiritual experience. The thought process of using your human capabilities of making the world physically and tangibly a more productive space. I always thought about sustainability as trying to make the world as least bad as you can, you will always leave a footprint. But permaculture is about leaving a good footprint.

That was the inspiration to apply for the farm manager position at the Cornell Student Farm, who was also doing some permaculture. I knew nothing about farming at that time. [...] There I developed my interest in farming." (wwoofer at farm 2, personal interview, 18 June 2015)

"The week-long experience I had on the CSA-farm was at least three years ago. I always remembered it. Once I realized how much I hated working in an office and sitting around all day, I remembered that." (wwoofer at garden 1, personal interview, 7 July 2015)

Likewise, it could be argued that the operator at farm 6 became exposed to farming through firsthand experience and the example of family members, too, growing up on his parents' farm. Yet, for him it was not mere interest that resulted from this experience, but a sense of a calling to carry on the family's farming legacy. 
"I think [farming] is just something I grew up with and figured it was something I was supposed to do." (farmer at farm 6, personal interview, 11 September 2015)

The satisfaction derived from hard, physical work was highlighted as a motivation by two of the farmworkers that were interviewed, both still in their twenties.

"I liked how you put in a lot of tangible work and then you reap the rewards of your hard work. I felt less emotionally and intellectually exhausted as with a lot of other jobs I have done including schoolwork, where you have to take a test and then you get an ambiguous thing. That made me come back to a farm." (wwoofer at farm 2, personal interview, 18 June 2015)

"One of the things I like about farming is that you get free exercise." (farmworker at farm 4, private conversation, 5 August 2015)

By the same token, two of the farmers made a reference to hard work that felt purposeful to them, almost using the exact same words:

"We do work a lot, a lot of hours, but it's rewarding."

(gardener at garden 1, personal interview, 14 May 2015)

"[Farming] is also hard work, but it is really rewarding."

(farmer at farm 5, personal interview, 10 July 2015)

Two of the farmers saw organic farming as a way to respond to environmental and social problems they were concerned about before starting their farms. For the operator at farm 5 , that insight led to the interest to learn more about farming and to volunteer on different farms, which eventually resulted in the decision to start their own farm.

"I studied journalism at college. I started to write a lot about environmental issues and the food system and how climate change and the food system were connected. I think this is where the interest first came from." (farmer at farm 5, personal interview, 10 July 2015)

The operator at farm 2, conversely, started a farm right away with a sense to contribute to a better world.

"I decided in 2008 because I went to Africa and saw the world needs help in this way, smallscale farming can save the world if land is open to those in need. I think small-scale farming is the key to feeding the world." (farmer at farm 2, email interview, 11 June 2015)

"I like to [...] feel useful to others." (farmer at farm 2, email interview, 11 June 2015)

However, despite being an economic necessity, making a living was only mentioned twice as a motivation to run a farm.

"I wanted to see if I could make a living farming and pull it off. I guess it is almost a personal challenge. I wanted to do it my whole life. I didn't want to do it as a hobby."

(farmer at farm 2, email interview, 11 June 2015)

"Our goal is it that we both can be full-time on the farm."

(farmer at farm 5, personal interview, 10 July 2015)

The reasons introduced up to this point were mentioned by two or more of the interviewees. Other motives, however, were unique drivers for only one of them. Independence, for instance, was a driver for the operator at farm 5.

"I love to be my own boss." (farmer at farm 5, personal interview, 10 July 2015)

That corresponds with her keen interest in self-sufficiency. 
"I would say self-sufficiency is really important. That's kind of what brought us into farming." (farmer at farm 5, personal interview, 10 July 2015)

Self-sufficiency was not that important to the other farmers who stressed the benefits of being embedded in a larger community (cf. chapter 5.2 Self-sufficiency and co-sufficiency).

In addition, the operator at farm 5 also mentioned the opportunity to work with her partner as a reason to have her own farm.

"[...] spending time together [... contributed] to us starting the homestead."

(farmer at farm 5, personal interview, 10 July 2015)

"I love to work with my partner." (farmer at farm 5, personal interview, 10 July 2015)

The reasons to farm introduced above represent the motivations of the farm operators, some of which were shared by their workers. Asked why they had chosen to work on someone else's farm, the workers gave a few answers unique to them.

To begin with, learning about farming was mentioned several times as a reason why interviewees wanted to work at a farm, which is especially true for volunteers. The volunteer at farm 1 , who was considering starting her own subsistence farm, named learning as one of her major reasons to wwoof.

"I read that people that consider farming as a career should at least spend three or four years working consistently to see if they really fit. So that is my guideline. A few years. "

(wwoofer at garden 1, personal interview, 7 July 2015)

The intern who was interviewed at farm 2 was less certain about starting his own farm. Yet, he, too, wants to learn about farming.

"I think I would continue to volunteer until I have enough experience to start my own farm or until I want to change my occupation. At the moment, the plan is to keep doing it and continually build up my understanding of how to build the ideal farm and look for the proper conditions to make that happen.

In terms of specific skills, I want to learn more about permaculture and forest farming. Very few people apply it on a market scale. It mostly is just gardens. Also I would like to work with animals because I think it is important to understand it before you express opinions about it." (wwoofer at farm 2, personal interview, 18 June 2015)

The same interviewee mentioned the introspection that working with plants offers as another reason why he continues to work on the farm.

"It's also a very personal experience, being in a field, weeding all day long. You are just with yourself for a lot of the time. It's a very silent work. I like that a lot. It can be very introspective. It can reveal a lot about yourself whenever you are working with plants. To me spirituality is very important which involves looking inward. Farming is a great way of working outward and looking inward." (wwoofer at farm 2, personal interview, 18 June 2015)

In summary, the interviews revealed various reasons why people decide to farm. The love of good and healthy food and working outside are frequent motivations among most of the interviewees. Furthermore, not being attracted by any other occupation, the merits of their agrarian lifestyles and the pride in feeding others, the rewards of hard, physical labor and the example of other farmers are also common drivers. Two farmers started to farm in response to their environmental and social concerns, while farming as a way to make a living has equally mentioned twice as a motivation. For many wwoofers, learning about farming was a major motive behind their volunteering. Reasons that were expressed only once were independence, partnership, calling, beauty and introspection. 


\section{2 "The Good Life": Self-sufficiency and co-sufficiency}

The farms that took part in this study engaged in production for self-sufficiency along with commercial, gainful production, albeit to varying degrees.

Farms 2 and 5 did not separate subsistence production from gainful production. They keep as much as they need themselves and sell the rest of their yield as commodities. The operator at farm 5 doubted that she would grow vegetables if she would not eat them herself:

"I love to cook, I love to eat them. I think if I didn't love vegetables I don't think I would have as much of an interest in farming. I don't really like to grow things that I can't eat as much."

(farmer at farm 5, personal interview, 10 July 2015)

What is more, farm 5 preserves some of their produce by making salsas, pickles and canning. These products do not get sold.

The operator of farm 4 said that one of his major reasons to farm was to make sure he gets good and healthy food and to avoid shopping at the supermarket. Running his own vegetable farm allowed him to do that. Unlike farms 2 and 5 , he also produces food exclusively for subsistence by keeping a pig for meat.

Farm 6 produces raw milk, raw cheese, yogurt, eggs and fruit alongside their commercial dairy business. These products are not solely for self-consumption, but also get sold at their on-site store. Their financial contribution to the operation's overall economy is marginal, but the farmer valued having all these products to eat and being in personal contact with customers.

The garden in this study is kept entirely for the subsistence of the family. Its yield, a wide range of vegetables, herbs, and fruit and eggs, is only used for home-consumption. When they get help from wwoofers, they also preserve produce through canning. The gardener linked her desire for beauty and fresh food with the good life, essentially the goal of subsistence (see chapter 4.2 Subsistence perspective).

"I think it is a quest for beauty. I want to be in a beautiful place and I want to eat food that is as fresh as possible, still warm from the sun. Which I guess is what I think is the good life. Just trying to live as good as possible." (gardener at garden 1, personal interview, 14 May 2015)

Farm 3 follows a different strategy to secure their subsistence. Their operation is mainly geared towards gainful commodity production and the money earned is used to buy consumer goods. Nonetheless, the woman farmer keeps chickens, collects fruit from their apple, cherry and pear trees and various berry shrubs, and cultivates herbs for their kitchen. They also cut their own firewood, and their hired worker keep bees for honey. They trade some of their products or services for food from neighbors and friends.

"... with the amount of trading that we do with other farmers, time is better spent for me focusing trying to make the farm work and have the farm produce income to buy those things and other products that I can trade for other food products that we need."

(operator at farm 3, personal interview, 30 June 2015)

Eating local food produced by themselves, friends and neighbors is a priority for the interviewed farmers. While many research participants regarded self-sufficiency ${ }^{7}$ as important, they stressed the fact that they rather meet their needs in community with other local producers.

The operators of farms 2, 5 and 6, as well as the gardener, valued self-sufficiency as important. Farm 2 decided to grow a diverse range of vegetables in order to have food for the whole year. The research participant at farm 5 reported that they started to homestead to be self-sufficient. Regardless,

\footnotetext{
${ }^{7}$ Understood by most interviewees as one's capacity to provide everything for one's subsistence using only self-controlled means of production (cf. chapter 4.3 Co-sufficiency and subsistence markets).
} 
most interviewees pointed out that they do not have to produce everything themselves because they know people who provide them with other local products.

"I would say that is really important. That's kind of what brought us into farming. At the same time, I do not think we need to do everything ourselves. We have that awesome bakery down the road. We are friends with a lot of livestock farmers, so we trade for vegetables or buy at the farmers' market." (operator at farm 5, personal interview, 17 September 2015)

One of the wwoofers at farm 2 criticized the concept of self-sufficiency, pointing to the burden that people take on for the sake of self-sufficiency.

"People get very obsessed about [self-sufficiency] for not very good reasons. [...] People go at great length to be self-sufficient and I'm not always sure what they need to sacrifice for that. Sacrifices to the earth, their family or their neighbors that could be getting more help from them. [...]

Sometimes your land isn't that well suited for covering all you needs but you force it to be." (wwoofer at farm 2, personal interview, 17 June 2015)

Instead, he advocated meeting one's various needs collectively, where each individual produces and supplies what they are best at and receives everything else from their community.

"To provide many people with one service and allow many people to provide you with what they have can be just as effective if not even more conducive to a functioning life than entire self-sufficiency." (wwoofer at farm 2, personal interview, 17 June 2015)

He pointed out that this cooperative effort of mutual provisioning creates community and strong social ties that would not exist if everyone would work on their own.

"Knowing other people that can help support you can be a very humbling thing. It helps creating relationships that are beyond just social. It strengthens social relationships in a big way." (wwoofer at farm 2, personal interview, 17 June 2015)

All interviewees expressed the sentiment that they prefer collective self-sufficiency, or co-sufficiency, over individual self-sufficiency.

The amount of food that the farmers produce themselves or get from people they are acquainted with varied from about $15 \%$ (the garden) to $90 \%$ (farm 5) of all products consumed throughout the year. In the winter it is especially more difficult to be self-sufficient than in the summer, when ripe vegetables are abound.

"We are] fully [self-sufficient] on vegetables, throughout the year. This winter was tough. It was so cold. Usually, even if it is cold, there is enough growing in the tunnels that we can get some. But it was so frozen for all of February and a lot of January that we just couldn't. I guess we bought some kale a few times, which was infuriating. Because there were greens in the greenhouse I couldn't get to." (operator at farm 5, personal interview, 17 September 2015)

"We don't go grocery shopping much. We produce milk, meat, eggs, cheese, yogurt. Usually the wintertime is when you have to go to the store because there's no produce here. I can't say no produce because there's carrots here right until the spring. My brother grows the vegetables..." (farmer at farm 6, personal interview, 11 September 2015)

The operator of farm 3 included trading in his understanding of self-sufficiency. They source more food for their own consumption through barter than if they were to produce everything themselves:

Man farmer: "Compared to the average households, we are way more self-sufficient with all the trading. But if you wanna take it to the extreme, we are not nearly there either. It would 
depend on if you were to compare us with the norm, yes, we are. If you compare us to some hardcore dudes that are out there hunting deer and cutting them up in their backyard." Woman farmer: "We do that!"

Man farmer: "I mean we have people that shoot deer and we chop them up ourselves and eat them. There's quite a lot of that." (farmers at farm 3, personal interview, 30 June 2015)

Lack of time, the complexity of necessary production and the dependency on industrial equipment were mentioned as obstacles to self-sufficiency. The gardener, for instance, reported that she does not have the time to preserve enough of her produce for the winter.

"Time is the limiting factor. With the help of wwoofers we can do more."

(gardener at garden 1, personal interview, 14 May 2015)

Likewise, the farmers at farm 2 and 3 mentioned the workload that producing for self-sufficiency comes with.

Man farmer: "If I'm using the definition of growing all of our own food and doing all that stuff, you could do that but that would be a full-time job.

Woman farmer: For both of us.

Man farmer: If she lost her job and wanted to raise meat chickens and pigs and a big garden and can that all, that would be a full-time job for her."

(farmers farm 3, personal interview, 30 June 2015)

"Time is pretty valuable, and growing, harvesting, and baking bread sometimes seems like it would take too much time." (farmer at farm 2, email interview, 11 June 2015)

The farmers at the grain operation commented on the complexity of producing the diverse range of products that would be needed for self-sufficiency.

Man farmer: "And I think there's a realization that you can only do so many things. In your brain you can go off and wanna do this and wanna do this but, honestly, just..."

Woman farmer: "The bottom line is that we are struggling to maintain what we've got."

(farmers a farm 3, personal interview, 30 June 2015)

They also considered it impossible to make the machines they need for their farm themselves.

Woman farmer: "But when I even think of self-sufficiency, we use so many products that we couldn't produce. All the farm machinery parts. I mean you make some of them..."

Man farmer: "Nah..."

Woman farmer: "But that's a few."

Man Farmer: "This farm could never be self-sufficient. This farm is so tied into the whole game." (farmers at farm 3, personal interview, 30 June 2015)

In summary, the interviewed farmers try to source most of their food from their own operation or from people they know. They like to meet their needs in the community, that is, they prefer cosufficiency over individual self-sufficiency, as well as reliance on store-bought commodities. Reasons that prevent farmers from full self- or co-sufficiency are lack of time through other work, the complexity of diverse agricultural production and the dependency on industrial equipment.

\section{3 "Relationships that are beyond just social": Community and co- operation}

Farmers around Ithaca are part of an informal community that is characterized by a mixture of mutual support, and to a lesser degree, competition. Interactions among farmers serve social and economic purposes simultaneously. Farmers build a supportive community by helping one another, which includes exchange of materials, products, labor, equipment and knowledge. While for each of these 
areas anonymous market solutions exist, the farmers prefer to meet their needs by making arrangements with people they know.

In the following, four fields of exchange that are embedded in direct social relations are presented. These are exchanges of farm products, labor, equipment and knowledge.

First, farmers exchange materials and farm products with each other. The operator of farm 3 , for instance, reported how they trade cover crop seeds for a CSA share and wheat cleanings for a pig.

"We're trading cover crop seeds to my vegetable farmer friends for a share of their CSA. The cleanings that I get from cleaning wheat from my flower mill are given to another guy who produces pigs and then we get a pig at the end of the year. Basically, there are a lot of meals here where we sit down and $90 \%$ of it is all from either us or people that we know."

(operator at farm 3, personal interview, 30 June 2015)

An important place in this trading economy is the Ithaca Farmers' Market. Farmworkers and wwoofers from farm 2 and 4 reported that vendors barter goods with each other. As an example, the vendors from farm 4 trade some of their produce for coffee and meals from food stands. Farm 2 barters their merchandise for either lunches or products they do not grow themselves. One of the wwoofers at farm 2 explained, how trading food does not only meet economic needs, but also builds community.

"Knowing other people that can help support you can be a very humbling thing. It helps creating relationships that are beyond just social. It strengthens social relationships in a big way. Trading things on the market is one of my favorite parts of it. You get to offer what you have and you get to take what other people are offering to you."

(wwoofer at farm 2, personal interview, 17 June 2015)

The relation between barter and communities goes both ways. Not only does trading build relationships, as exemplified above, but social ties can foster exchange, too. The operators at farm 5 swap vegetables for fruits and meat with friends. The operator of farm 3 explained how his friendship to his trade partners encourages exchange without using money:

"[...] trading with other farms that produce something that you don't produce. And you produce something that they don't produce and you both need what each other got. You could do a straight up cash thing but a lot of times...these people are friends of mine, first of all. We love to have fresh vegetables. We don't have the time to have a garden. What a great thing to be able to trade cover crop seeds with them or whatever that might be for a vegetable CSA share or some meat. That system feels really good to me."

(operator at farm 3, personal interview, 30 June 2015)

Even when money is included, the direct social contact between trade partners fosters solutions that benefit both.

"I've got another farm where I rent one of their fields on their farm in exchange. They don't charge me any rent but they called me last night, they are building a straw bale house, they need straw bales. I said normally they are four bucks but I sell it to you for half price because you give me my thing and then I give them cover crop seeds for their vegetable farm and they let me use their land for free." (operator at farm 3, personal interview, 30 June 2015)

This network of economic relationships outside the conventional, money-based marketplace can be described as an informal trading economy. Unlike the capitalist market economy, it is not build on competition but on reciprocity and is embedded in a community based on personal relationships. It is an example of a subsistence market as described in chapter 4.3 (Co-sufficiency and subsistence markets).

On the other hand, there are a lot of transactions within the studied farming community that include the exchange of money, but are guided by the same values mentioned above. For example, the op- 
erator at farm 3 founded a flour mill to give grain farmers an opportunity to locally process their crops and to obtain better prices than they would get at a place where the farmers would have to compete with operations from naturally more productive regions. The exact fees are negotiated between the farmers and the mill, with the aim to reach a result that is satisfying to both parties.

Man farmer: "The guys I'm working with selling their crops, I pay them really well for their stuff. Way more than they gonna get anywhere else. So they're really excited to grow stuff for me. I just make sure that my margin that I take on is not so much that everybody gets a chunk of the pie. If I'm gonna sell it for $x$ amount I want the amount I make to be the same as what the guy I'm buying it from is. So I'm not making all the money that the middleman normally does. That income is more balanced between what the grower has and what I have." Woman farmer: "The transparency is a big part of his philosophy."

Man farmer: "Yeah, that's what I was just trying to describe."

Woman farmer: "You know, 'if I can make a certain amount that's fine' and he's actually happy to spread the wealth."

Man farmer: "I always tell them 'OK, I'm gonna make three cents a pound to clean it and I'm gonna add two cents a pound to that for my time and marketing and all that. Does that sound fair to you? So there isn't any mystery in who is making what."

Woman farmer: "If they can make an extra three cents a pound on it then that's great and everybody is happy."

Man farmer: "That builds a lot of loyalty in the guys that grow for me. They know I'm looking after them. I'm not trying to get rich off of them."

(farmers at farm 3, personal interview, 30 June 2015)

In this case, the distinction between cooperation, social activity and economy is arbitrary. Within the observed farming community of the Central Finger Lakes, economy is often a cooperative, social activity for the mutual best of each participant. It is the production for co-sufficiency (cf. Chapter 5.2 Self-sufficiency and co-sufficiency) that creates community. Whether money is involved in these transactions is less relevant than the values that govern them. Does the community facilitate this moral economy, or is the latter a result of the former? Either way, there is a strong connection between the two.

The second field of exchange is built around labor. As an example, during certain times of the year, the operator of farm 3 gets help from a sheep dairy farmer:

"I have another friend who helps me out from time to time. They have a sheep dairy. If I'm really desperate he'll come over and work. He probably works five days a year. But sometimes it's like 'Hey, can you come over and help us with the hay. 'And then he'll come over and we do that on a trade basis. They get feed for their sheep and they give us yogurt."

(operator at farm 3, personal interview, 30 June 2015)

Farm 5 has started a formalized work trade scheme. Interested persons can sign up for a three hours shift in return of a CSA share. While this trade does not occur among farmers, it is a non-monetary exchange with consumers and gives landless people an opportunity to farm themselves. The farmers valued this support not only for the extra workforce, but also for the company.

"It's great, too, because people are able to come and learn and get vegetables and we have all this help. It's fun having other people around. I think it is good for my partner and me to have other people around, helping us. Because it can get lonely."

(operator at farm 5, personal interview, 17 September 2015)

The scheme originally came into being through the initiative from an interested customer. The farmers then promoted this work trade opportunity to get the help they needed.

"One day, it was our first year of CSA pickup, early on in the season, this guy came up to us and said 'Hey, I worked on farms before. Can I work in exchange of a share?' And we were like: 'Who is this guy? Whatever, OK, fine, you can do it.' And now he is one of our best friends. [...] 
So he was our first work share. The next year we kind of formalized it a bit more and advertised it a little bit more and get more people helping us and this year we decided to do it even more because we knew we would be building our house and we would need all the help we could get on our farm. We got a lot of interest and we have a good number of people helping us." (operator at farm 5, personal interview, 17 September 2015)

The agricultural career of these two farmers started in a similar fashion. Before running their own farm, they looked after a homestead for a couple who had moved to a different city. As compensation for their efforts, they got to stay at the homestead for free. One of the workers at farm 4 lives under a similar arrangement. He tends the private property for a family in a nearby town, and in return, he gets to live there for free and keeps a small vegetable garden for himself.

Another form of cooperation is the custom work of farms 3 and 6 . While this service is usually paid for, it is still regarded as a favor among friends. For instance, the operator of farm 3 both harvests corn for other farmers and has someone else bringing in his crops when needed.

Man farmer: "We do custom work. That neighbor here has 20 acres of corn and he wants me to combine it and I come over and harvest it for him and he would pay me a certain amount per acre to do that. There's another crop farmer, neighbor, friend. He's about twice my size, he's a conventional farmer. We have some big equipment but his equipment is really big. So I get him come over here with his big fancy combine and combines for me. And then I'll pay him like \$32 per acre. He comes over with his machine and his trucks, harvest my crops, brings them over to me, I put them in the bins. It just saves us having to buy a $\$ 200,000$ machine that is that big and fancy.

Woman farmer: Or he can come over when we know it's gonna rain tomorrow. And he comes over... according to his schedule.

Man farmer: And get a lot more done. And he does a great job. And he is a good friend so I don't mind giving him the money. We do a lot of business back and forth."

(farmers at farm 3, personal interview, 30 June 2015)

Besides paid custom work, farmer 3 also helps out on other farms with his machines in return for services or materials.

"Sometimes I'll go and somebody needs a field plowed or a guy has 5 acre of rye on his vegetable farm and needs it harvested so we go over and do that in trade for who knows. They might come over to help stack hay in the barn. So there's a bit of work trading going on." (operator at farm 3, personal interview, 30 June 2015)

Thirdly, some farmers share equipment with each other. Farm 2, for instance, shares their disk harrow with a neighbor and farm 3 uses their mowing equipment together with a sheep farm. Equally, the gardener in this study also shares some equipment with neighbors. The operator of farm 3 planned to jointly purchase and use an expensive baler with a neighbor farmer. These exchanges function because the participating farms need the machines at different times.

Not all farmers share their equipment, however. The operator of farm 4 used to borrow a tractor from his father's farm but stopped doing it once he bought his own.

"Now I have my own tractor and I'm too busy to use someone else's tractor. When I need to get something done I need to get it done. I can't wait."

(farmer at farm 4, personal interview, 1 July 2015)

Farm 6 generally does not let others use their equipment, either.

"Every once in a while, but no, farmers don't usually trade machinery because then stuff gets broken." (farmer at farm 6, personal interview, 11 September 2015)

Farm 5 is situated too far away from any neighbor they could share machines with. 
According to the accounts of the research participants, there are prerequisites for successful sharing of equipment: First, there need to be a farm nearby which is willing to cooperate. Secondly, the partners need to have dissimilar production systems, using the machines at different times in the season. For that reason, it is helpful if the partners grow different crops with complementing planting and harvesting times. Thirdly, the partners need to have precise arrangements about the use and responsibilities for repairs.

The fourth type of cooperation within the Ithaca Farming Community is the exchange of knowledge and experience. Usually, information about farming are shared without the expectation of reciprocity.

The operator of farm 3 wants to pass on his expertise to younger farmers as he approaches retirement.

"I feel it's really important for farmers in their fifties like me who were farming for a while and have some experience, we made a lost of mistakes, so we can share those and share things we did right so the next generation of farmers, a lot of them did not grow up on farms, like me. Pass on what we know." (operator at farm 3, personal interview, 30 June 2015)

In contrast, younger farmers, like the ones from farm 5 and 6 appreciated the advice they get from more experienced farmers.

"That's one thing about the organic community of farmers, you can just call them up and they'll tell you how they do things." (farmer at farm 6, personal interview, 11 September 2015)

The operator at farm 5 valued the support from both local and more distant farmers:

"Other farmers are a huge resource. There are a lot of online forums for both local farmers and nation-wide. Like when you have a disease on your tomato you send a picture and someone always knows what it is.

We listen to farmer podcasts. They are helpful."

(operator at farm 5, personal interview, 17 September 2015)

According to the organic grain farmer, the community in general is willing to share knowledge.

"I think farmers are really willing to share information with each other and help each other. The community in general is like that." (operator at farm 3, personal interview, 30 June 2015)

Beside the informal, peer-to-peer exchange of experience, there are more organized systems in place to facilitate the distribution of knowledge. For example, farmers in the Ithaca area set up regular events, such as dinners or potlucks, where farmers meet to socialize and share their experience.

"There are also these social events that are happening. A local pig farmer has a Monday night dinner. Every single Monday night they cook dinner. [...] There is also a monthly potluck. I don't quite know who does that but there's an email coming around and it rotates at which house it is at. These events are more socially oriented, but there's certainly a lot of farming talk going on." (woman farmer at farm 3, personal interview, 30 June 2015)

In addition to these informal meetings, there are dedicated organizations or networks whose mission is to connect farmers. For instance, New York Certified Organic (NYCO), a self-organized group of organic grain and dairy farmers sets up periodic potluck meetings for farmers to get to know each other and learn from one another. The interviewees at farms 3 and 6 often attended and highly appreciated these meetings:

"[NYCO] have meetings usually once a month. They have speakers that talk. Farmers come in and talk. Everybody will share. They pick out a topic and then everybody will share ideas. Starting out, those meetings where really important to me. That's where I got a lot of my 
mentorship. Going to these meetings, having a lot of experienced guys, asking the dumb questions and having guys go 'Oh, yeah, try that, try this, try that,' and getting to know older farmers that I could call and ask questions.

That organization, NYCO, is fairly unique and has been modeled by other states in terms of farmer mentorship program. It is a really great program. I can't imagine having started in organic farming without that as a place to go and ask questions. It is very open. The atmosphere is very friendly and sharing. Everybody brings something for lunch. There is a speaker and then discussion. But that's only in the winter."

(operator at farm 3, personal interview, 30 June 2015)

"In the winter time they usually have meetings over in Geneva at the Cornell Research Station that the organic farmers put on, it's like a potluck meeting, everybody brings something.

Somebody is usually presenting but everybody usually chimes in with what they think and they're usually pretty good meetings."

(farmer at farm 6, personal interview, 11 September 2015)

The Groundswell Center for Local Food and Farming in Ithaca is another example of a bottom-up, community-based organization which aims to connect farmers and to offer training, especially for beginners. Farm 5, for instance, partnered with Groundswell to hold a high-tunnel course.

Besides these local, farmer-organized events and training, there are larger, state-wide support networks that set up meetings for farmers in the Finger Lakes Area. The most relevant ones in this respect are Cornell Cooperative Extension (CCE) and the Northeast Organic Farming Association (NOFA). Cornell Cooperative Extension is a federally funded outreach organization based at the College of Agriculture and Life Sciences at Cornell, New York's agricultural college. CCE's mission is to disseminate publicly funded scientific research and innovation to farmers. The Northeast Organic Farming Association, on the other hand, is a large organization of farmers throughout the U.S. Northeast that certifies and educates organic farms. While both CCE's and NOFA's events tend to be arranged by paid staff, delivering expertise from academic researchers, they are nonetheless a platform where local farmers meet and share their own experiences. Farmer 6 appreciated information he gets from Cornell, while, at the same time, valuing the real-life perspectives of other farmers.

"Cornell is great for research but they're not out in the field all the time. They're reading research, putting stuff up and all that but they're not actually out changing the angle of the weeder, it definitely helps to talk to a farmer who has done it."

(farmer at farm 6, personal interview, 11 September 2015)

In general, most of the research participants praised the local farming community as an important source of support. The farmer at farm 5 highlighted that she immediately felt welcomed when she started out.

Interviewer: "Did you find it difficult to be accepted by the farming community here as a newcomer?"

Farmer: "Not at all. Everybody is really supportive. It is really a great place to be a farmer." (operator at farm 5, personal interview, 17 September 2015)

The interviewee at the dairy farm suggested, however, that the organic farming community is much more helpful than the conventional one is.

"As far as talking to other farmers, usually farmers don't talk to each other as far as what they do and how they do things. Organic farmers are more supportive.

Mom and Dad called a consultant in who told them to call in an auctioneer and by the way my fee is $\$ 1500$ dollars and I'll be on vacation for a couple of weeks so you can't get a hold of me. That's all the help the conventional world was."

(farmer at farm 6, personal interview, 11 September 2015)

Apart from farm 6, which converted to organic 16 years ago, none of the farms that participated in the research has ever been conventional. That is, when the other farmers talk about the farming 
community, their account might be biased by their experiences within the organic community. However, some of them do work together with conventional farmers as well.

Despite the cooperation among the farmers in the Ithaca Local Market Area, a sense of competition among farmers does exist. There seems to be a perceived necessity to be profitable to stay in business and the failure of other farms is seen as an opportunity.

"Basically in farming everyone's out for themselves. I don't think farmers want to see other farmers go out, but if they do then it's an opportunity for them."

(farmer at farm 6, personal interview, 11 September 2015)

"We will be forced to compete with other small farmers instead of the multinationals." (farmer at farm 2, email interview, 11 June 2015)

The operator of farm 5, in contrast, has not been worried that competition with other farms will be an issue:

"[...] you always wonder about growing your competition [when you teach beginning farmers], but I think it is more important that people eat good food. We have found our niche and farms tend to find their niches."

(operator at farm 5, personal interview, 17 September 2015)

In summary, the farmers of the Central Finger Lakes Region cooperate in many different ways, especially through the exchange of materials, products, labor, equipment and knowledge. These interactions are embedded by values of reciprocity, transparency and mutual support. Some of the material exchanges occur on the conventional, money-controlled marketplace, whereas others take place in an informal trading economy. While much of the distribution of knowledge happens on a peer-topeer basis among two farmers, group meetings and lectures, organized by individuals, bottom-up networks of farmers and professional associations and extension services facilitate the flow of information as well. These activities are strongly linked to a pronounced sense of community. This is in contrast with competition between farms that some of the interviewed farmers perceive and have mixed feelings about.

\section{4 "Locked into the System": Subsistence-oriented farming in a capitalist world}

While all the farms were involved in subsistence production, none of them has built a livelihood solely on these activities. All interviewed farmers perform gainful work to buy commodities for their subsistence. This can be off-farm work or production of agricultural commodities for sale. Only the wwoofers farm without having to work for money, but they, too, rely on the money-dependent economy of their hosts.

The motivations that drive the participating farmers (see chapter 5.1 Motivations to farm) suggest that subsistence is their primary production target. Good food, being outside, the good life off the land, feeding others, making a living, independence, self-sufficiency and working with a partner were mentioned as reasons to farm. Each of these drivers constitute an aspect of subsistence. None of the interviewees regarded farm growth, accumulation of capital or financial wealth as a motivation. The only operation that expressed a desire to keep growing, farm 6 , regarded growth as a necessity to stay in business, not an end in itself.

"If you don't continue to grow you die in the farming business."

(farmer at farm 6, personal interview, 11 September 2015)

The gardener mentioned that the dependence on money forces her to do gainful work. 
"No, I wouldn't [work off-farm if I could live entirely off my land]. I do like going to town. It is interesting and fun. But if I wouldn't have to worry about money I would just do voluntary things." (gardener at garden 1, personal interview, 14 May 2015)

The dependency on monetary income is the main reason many of the interviewees deemed subsistence farming impossible in today's United States. Farmers need money to pay taxes, land, inputs, equipment and other commodities.

"I do not consider myself a subsistence farmer. It is not possible today. You have to sell things. Many will not be able to farm because the cost of inputs and taxes will increase."

(farmer at farm 2, email interview, 11 June 2015)

"A peasant farmer to me is someone who farms on a very small, almost subsistence-like scale. In my mind I see somebody who is very poor in a material way but not so in a spiritual or family way. Not as tied and locked into the whole capitalist financial system that I find myself completely bound in." (operator at farm 3, personal interview, 30 June 2015)

Some farmers are tied into surplus production by the loans they have taken out to finance parts of their operation, exemplified by farms 3, 4 and 6 in this study (cf. chapter 5.7 "I used to really not wanna be in debt and now I don't give a shit": Debt). Debt forces the farms to produce more than what they need for their subsistence to service loans and interest. Although the farms with the highest financial obligations, farms 3 and 6 , were not concerned about it, debt is still a circumstance that drives them to commercial commodity production.

The prevailing logic of capital accumulation puts other stresses on agricultural producers as well. The woman farmer at farm 5 explained that it would be much easier for them to live off the land if they did not have to compete with operations from distant, yet more productive areas.

"We have to work pretty hard to sell produce but if we didn't have the competition from really cheap California produce... which blows my mind that produce that gets shipped over from California is still cheaper...so I think maybe in 20 to 30 years it won't be as hard anymore.... If California has only one year of water left, they can't keep producing $75 \%$ of the produce for the country. It's just not going to work. I think this will help farmers everywhere."

(farmer at farm 5, personal interview, 10 July 2015)

Another problem farmers who are part of the capitalist organization of agriculture are facing are government regulations that allow private companies to create monopolies on seeds. Farmer 2 explained:

"The government has a strong influence on farmers and it usually works in favor of big companies. Some companies are now able to buy up most of the seeds and, thus, create new dependencies for small farmers." (farmer at farm 2, email interview, 11 June 2015)

This is not to say that growth-oriented and industrial agriculture is only disadvantageous to farmers. For instance, some of the participating operations use the manure from industrial, organic poultry farms as fertilizer.

"In a way we benefit from industrial agriculture because our fields are completely fertilized by composted chicken manure that comes from an organic capon. If that was to end then we would have to reassess how we are fertilizing our fields.

Industrial agriculture definitely still affects local, small, organic farming. And sometimes even for the better. Our vegetables wouldn't be as big if we didn't have that chicken manure."

(farmer at farm 5, personal interview, 10 July 2015)

For the operator of farm 3, this is an ambiguous situation. He disapproved of the methods used in industrial animal husbandry, but at the same time depends on it as a source of organic fertilizer. 
"I see that [industrialization] really in animal agriculture and I think it is horrendous. That said I get all of my fertilizer from these giant, industrial chicken farms. I can say that I think it's horrible, but I can also say that that's being two-faced because I buy their chicken manure and spread it on my fields. It is a good way to get a concentrated amount of manure for someone like me who is relying on manure. But that manure is coming out of this really horrendous farming system that I actually despise.

So I really feel at odds with that whole thing but also don't know what else to do. I don't have an alternative." (operator at farm 3, personal interview, 30 June 2015)

The operator of farm 3 revealed internal conflicts. While being proud about his achievements, he appreciated the idea of subsistence farming and has been concerned about the sustainability of his operation. At the same time, he did not know how to do it differently.

"A subsistence farmer to me would be somebody who's just making all their food themselves, living very simply, not have all this capital crap that I have got here and trying to farm these huge amounts of land. There is nothing subsistence about us."

(farmer at farm 3, personal interview, 30 June 2015)

"We are locked into the system. It's a commercial organic farm. It has its really great points and it has a lot of environmental benefits, but it's also not a system that I can say I am a $100 \%$ behind either." (operator at farm 3, personal interview, 30 June 2015)

To sum up, the participating farmers engage in commercial, gainful work. For many of them, it is a burden they have to put up with in order to farm. The reasons that drive them to live off the land suggest that the interviewees are oriented towards subsistence. The capitalist organization of agriculture in the United States forces farmers to engage in commodity production or off-farm work to gain access to land, buy inputs and equipment, as well as service loans and pay taxes. However, some farms also benefit from industrial agriculture that provides them with fertilizer. The contradictions between personal ideals and the capitalist economy they operate in puts stress on some of the research participants.

\section{5 "We want to grow, but also to shrink in size": Farmers' relation- ship to growth}

The interviewees had differing opinions about whether they want their operations to grow. The answers ranged from desired growth to shrinking in size.

Farm 6 was most strongly geared towards growth, which the son of the main operator considered a prerequisite to maintain the farm:

"If you don't continue to grow you die in the farming business. [...] I mean we could stay where we are and do decent, especially doing milk and being organic, which doesn't go up and down and change drastically, we'd probably be alright, but we need to keep going." (farmer at farm 6, personal interview, 11 September 2015)

This statement reveals an understanding of growth that is akin to a dogma. Despite admitting that the operation does not have to grow to stay in business, the farmer feels the urge to expand the operation. This idea reveals the long-lasting legacy of former U.S. Secretary of Agriculture Earl Butz (1971-1976), who demanded farmers "get big or get out" and established a policy that favored large, corporate farms. Seemingly, this maxim has become a matter of course to the point that farmers submit to it even though they question its economic justification.

The operator at farm 5 also wanted to keep growing the farm, but only to a certain size. 
"Our goal is it that we both can be full-time on the farm. That has made me think how big do we need to get to be able to support ourselves. And if we are going to support ourselves we really need to have an employee. [...]

I want to stay a place where I am still touching plants and soil on a regular basis. That's my favorite thing on a farm. I love planting. That makes me really happy.

As long we are at a scale where we are still doing some of the work, but maybe not all of it, I think this is where we are heading."

(operator at farm 5, personal interview, 17 September 2015)

This farmer was not interested in growing the farm infinitively, yet felt a need to scale up in order to reach a level that feels right to her. However, she wondered if that target level might change once she reaches it like it has in the past. Asked whether she wants the farm to grow beyond the point where the farm supports her and her partner full time, she replied:

"I would say no, but every thought I had about farming has evolved over time." (operator at farm 5, personal interview, 17 September 2015)

The operator of farm 5 had a different opinion on growth:

"Yes, we want to grow but also to shrink in size. To be more efficient and focused and not expand our acreage anymore. We grow in many ways, spiritual is most important."

(farmer at farm 2, email interview, 11 June 2015)

Unlike for the aforementioned farmers, the desired growth of this farm is independent from its land base. First, it has been perceived as an increase in output through intensification. Second, the farmer wanted to grow spiritually without specifically explaining what that means for him.

In the same fashion, the operator of farm 3 wanted to reduce his acreage. Unlike the operator of farm 2 , however, he also intended to extensify his production. He did not have any interest in further growth, realizing they had passed their ideal scale and had become too big.

"I'm not gonna get more land. I want to start cutting it back. I think I will turn more of the land that I have in production into cover crops and fallow. Sort of let the land sit a little bit more and not farm it as intensively. Maybe not cut back the acres so much but cut back the intensity of how we are farming it. Leave more of it in cover crops and clover and things like that and let the soil build and regenerate a little more than we've been able to do.

[...] I definitely wanna go backwards instead of forwards in terms of acreage. We're farming too much land now." (operator at farm 3, personal interview, 30 June 2015)

This farmer wondered whether the "get big or get out" dogma has any economical basis:

"It would be interesting to do some research about shrinking the operation back and see 'Am I really making more money?' There's a natural tendency to think 'more and more and more' and 'bigger is better' but I'm not sure if that's true."

(operator at farm 3, personal interview, 30 June 2015)

The two biggest operations that participated in the research, farm 6 and farm 3 , had the most opposite views on farm growth of all the farms that were surveyed. The former saw growth as a necessity of the future of his operation, whereas the latter aimed to shrink in size. A significant difference between the two farms in this regard is that the former is in the process of transferring the operation to the two sons, whereas the farmer of the latter does not yet have a successor. This is in line with findings from POTTER and LOBLEY (1992) and SOTTOMAYOR et al. (2011) that show that extensification in agriculture usually occurs at the end of a farming career, especially when no successor is present.

In any case, reducing the opposing views on growth to the question of investments and succession is to ignore the argument made by the operator of farm 3, that smaller farms might be just as profitable as large ones. 
The gardener is somewhere in the middle of the range, neither wanting to grow nor to shrink materially:

"No, I really don't see any need for it. I just want it to get more lovely. And more fun." (gardener at garden 1, personal interview, 14 May 2015)

She seemed to be content with the scale of her garden. Like farm 2, she was more interested in immaterial growth, a life that is more beautiful and fun.

\section{6 "My role ends up to be more ambiguous": Labor}

There were notable differences in the level of workforce used at the surveyed farms, depending on the scale and the kind of the operation. Growing vegetables, which requires a lot of manual work, is much more labor intensive than the heavily mechanized cultivation of grains. By way of illustration, farm 4 , an organic vegetable producer, employs seven workers full-time throughout the year (one works half-time while his college is in session) on 47 acres (19 ha). Farm 3, in contrast, hired only one full-time and one half-time worker, the latter just during the summer, to run their 1200-acre (486 ha) organic grain operation. That is roughly $0.15 \%$ of the per acre workforce than farm 4 . Dairy farming ranges somewhere in the middle of the labor intensity scale. Farm 6, which runs a 2300 -acre (931 ha) dairy operation with 700 cows, employs 13 full-time workers besides the operator and his two sons. That is roughly three times as much labor per acre than the grain operation, but still only $4 \%$ of farm 4.

Scale is another factor for the necessary workforce. For example, both farm 4 and farm 5 offer a vegetable CSA, but differ in the number of people working on the farm. While farm 5 manages to prepare 75 shares on 5 acres ( 2 ha) with the equivalent workforce of two full-time workers, farm 4 needs eight full-time workers to produce 250 CSA-shares on 47 acres (19 ha).

The garden cannot reasonably be compared with the commercial farms in this respect. Unlike them, the gardeners do not rely on the yield of their production, and their goal is not food alone, but also a beautiful landscape.

The numbers above are not to imply any rule, or even a rule of thumb, about the necessary workforce of an operation. The sample is too small and the examples too diverse to make any sensible, quantitative statement. Yet, they demonstrate the variety of the farms that took part in this research and suggest scale and production target as two major determinants for the labor demand.

Aside from total numbers, the workforce of the farms also differed in social parameters. Besides the operators themselves, there are family members, volunteers, paid employees and occasional contractors and helpers working on the farms investigated.

Each of the farms, as well as the garden, make use of family labor to some extent. At farm 2, farm 5 and farm 6 , as well as the garden, family members participate in the work on the fields or pastures. At the garden, the retired father of the operator is responsible for much of the manual and routine labor, such as cleaning the pond, mowing the lawn, construction and repairs. At farm 2, the wife of one of the operators and brothers grows and processes herbs. His cousin manages the fruit trees, besides doing other chores. The younger brother's girlfriend helps market their products. The wife of the operator at farm 3 secures the logistics of the operation by running errands and transporting people and equipment, tends the chicken and horses and is in charge of the productive household work. At farm 5, the two operators are also life partners and do most of the work together. What is more, the cousin of one of the farmers works and lives on the farm for the summer. In the case of farm 6, the two sons of the operator work full-time on the farm. Their situation is different from the other family workers presented above, since they are hired like non-family farmhands. The operator's wife at farm 4 does not work on the field. Besides her full-time off-farm work, she prepares and processes farm products for market and for home-consumption and cares for the children. 
Paid farmworkers work on four of the six visited farms. The grain farm hired an Agricultural Sciences graduate from Cornell as their main assistant. He participates in most of the productive activities and lives on the farm as well. They have another hired man on the farm, who works three days a week in the summer. The 47 -acre (19 ha) vegetable farm hired seven young men who work in the field, mainly planting, weeding, harvesting and cleaning. The smaller vegetable farm in this study employed one part-time worker for ten hours a week for similar chores as the farmhands on farm 4. Farm 6 had 13 full-time workers in addition to the senior farmer and his two sons.

One of the workers at farm 4 said that he works on the farm to save up money and get experience so he will be able to start his own operation in the future. Another worker also saw the work as training in agriculture, as well as a chance to grow his own food.

There are three different kinds of volunteer workers on the studied farms; i.e., farmhands who do not get paid with money. These are interns, wwoofers (members of World Wide Opportunities on Organic Farm)] and work-traders.

Farm 3 has one intern who comes in once a week. She wants to become a grain farmer and receives training from the operator while helping out with various chores. Farm 6 offers internships as well.

Two of the farms host volunteers through the WWOOF network. World Wide Opportunity on Organic Farms is an international organization with the mission to connect interested volunteers with organic farmers all over the world. Through this scheme, volunteers commit to work four to eight hours five days a week in return for board and lodging, depending on the specific arrangement with the hosting farm. The stays can be anywhere between a day and a whole season.

The gardener hosts one long-term wwoofer, a 25-year-old woman from New York City, who stays at the place for several months. She works four to six hours, three days a week, and two days at the gardener's sister's house in Ithaca. The wwoofer regarded the gardening as an opportunity to learn about farming, which she is considering as a career.

Farm 2 hosts six long-term wwoofers, women and men in their twenties. They work eight hours a day for five days a week and live on the farm. One of them pointed out that the reward for their work is beyond food and shelter:

"I get treated as family. I get the implicit support of the family, which essentially means that they are willing to feed me, provide me with a place to live and then take care for any other of my basic needs that I have." (wwoofer at farm 2, personal interview, 17 June 2015)

This is in line with the account from the wwoofer at the garden, who also named the social relationship to her hosts as one of her most precious impressions while wwoofing:

"The social experience has been almost the most valuable. It is very different from my experience back in the city.

My host and her sister don't have much boundaries. From the very beginning they have been very open and just folded me in to the group. Without much of a screening process or anything." (wwoofer at garden 1, personal interview, 7 July 2015)

Besides board and lodging, she regarded fun and knowledge as the rewards for her work.

"Food, shelter, fun. My host is a lot of fun and she takes me on trips sometimes. Knowledge and experience. If I want to, I can take advantage of [my host's] vast library. She has a lot of books about gardening and farming. And she herself is a very good resource."

(wwoofer at garden 1, personal interview, 7 July 2015)

The interviewed wwoofer at farm 2 pointed out that volunteering is different from wage-labor, as paid workers usually do not get the same emotional support from their employers. 
"They are willing to feed me, provide me with a place to live and then take care for any other of my basic needs that I have. As well as catering to my less basic needs, like emotional needs that I feel paid workers might not receive in the same way.

It builds a more subjective relationship between employer and employee."

(wwoofer at farm 2, personal interview, 17 June 2015)

On the downside, not having a defined work agreement can cause problems, as labor conditions and expectations have to be constantly renegotiated:

"[The subjective relationship to the employer] can sometimes be more challenging, because there are not as many hard and fast rules and less sense of the kind 'I pay you this and therefore you do this.' It ends up more to be a conversation; the terms of living, what I want out of the farm. My role ends up to be more ambiguous."

(wwoofer at farm 2, personal interview, 17 June 2015)

Another type of volunteer who works on the participating farms are work-traders, or work shares. Twelve volunteers help out under the CSA work share scheme set up by farm 5 . They commit to a three-hour shift once a week in return for a CSA share, in this case, a free-choice selection of fresh produce each week. This way, consumers can get involved in the growing of their vegetables and save on food expenses.

The last kind of labor was occasional contractors and helpers. Farm 3, for instance, sometimes asks another farmer to harvest their field during peak workloads for a per acre price. Around five days a year, they also get help from a farmer they are friends with. The same goes for farm 2, where friends of the operators help out on demand from time to time. These arrangements are part of the cooperation and informal trading economy among the farming community described in depth in chapter 5.3 (Community and cooperation).

In conclusion, the workforce of the investigated farms varies widely, both in size and in social parameters. The labor demands depend mostly on the scale of the operation as well as the production target. Growing vegetables is more labor-intensive than dairy farming, which again requires more manual work than the cultivation of grains. Based on the relationship of the workers to the farm, labor can be distinguished into family labor, paid labor, interns, wwoofers, work-traders, contractors and the occasional helping friend.

\section{7 "I used to really not wanna be in debt and now I don't give a shit": Debt}

There is a sharp divide between the agricultural producers who participated in the research about the willingness to take on debt. On the one hand, there are farmers who avoided borrowing money. This group is represented by farms 1,2 , and 5 . On the other hand, there are operators who considered debt as part of their business, namely farms 3,4 and 6 .

It appears as if being debt-free is a value in itself for some farmers. None of the interviewees explicitly mentioned to what end they try to stay away from debt, but they stressed that they go to great lengths in order to avoid it.

"I don't wish [being in debt] for anyone else but I'm not experiencing it myself. I try really hard to pay for everything." (gardener at garden 1, personal interview, 14 May 2015)

"We have been able to farm without debt. We have grown very gradually and the not-havingto-pay-rent situation had enabled us to have a viable farm and grow it and buy land and to do the things we wanted to do." (operator at farm 5, personal interview, 17 September 2015)

The operator of farm 2, also not indebted, suspected that banks increasingly favor large agricultural producers: 
"The banks will be wary of giving out money to farming operations smaller than 1000 acres." (farmer at farm 2, email interview, 11 June 2015)

The interviewees who accept debt had a different attitude towards it. They regarded loans as a prerequisite for their style of farming.

"I think it is sort of unavoidable in a business like this to not take on debt. You just gonna have debt. You just live with it." (operator at farm 3, personal interview, 30 June 2015)

In particular, the equipment these farms use is too expensive to be paid for up front.

"You pretty much have to [take out a loan] with how much this stuff costs."

(farmer at farm 6, personal interview, 11 September 2015)

The operators at farms 3 and 4 , as well as the father of the gardener, have also borrowed money to buy machines. The latter two used zero or low-interest loans offered by the seller to finance their machinery.

"The equipment dealers are always trying to get you to buy stuff so they have some pretty sweet low-interest stuff. I tried to take advantage of that and just keep paying down on it." (operator at farm 3, personal interview, 30 June 2015)

Despite borrowing money for their operation, these farms try to keep their debt low. For that, they use various strategies. The operator of farm 3, for instance, attempts to utilize low-interest rates, besides using the special loan offers from the equipment dealers mentioned above.

"I've tried to borrow when the interest rate was low, and when it was high we didn't borrow money." (operator at farm 3, personal interview, 30 June 2015)

"The U.S. government has super low-interest grain storage loans. We have taken out a bunch of those to put up bins." (operator at farm 3, personal interview, 30 June 2015)

Another strategy he uses is to restrict loans to machines and facilities. He keeps cash reserves and saves his own seeds in order to be independent from creditors when it comes to replanting.

"I don't take out any money to plant my crops. I save my own seed; I clean my own seed mostly. I try to keep enough money in the bank so if we had a really bad year I could plant again." (operator at farm 3, personal interview, 30 June 2015)

The operator of farm 4 controls his debt by limiting loans to the most urgently needed pieces of machinery.

"I got a loan years ago for the tractor and other equipment. I didn't take out another loan for something else, even though I could use another tractor, a cultivator and some other stuff but you can only do something." (farmer at farm 4, personal interview, 1 July 2015)

Farm 6 manages their debt load by restricting the money they borrow to the amount they can service using their own income.

"We try not to overextend, you know you're not supposed to borrow more than you can pay back. Make a budget." (farmer at farm 6, personal interview, 11 September 2015)

Both the operators of farm 3 and farm 6 , the largest farms with the biggest debt loads who took part in this research, explained that the debt does not concern them.

"It doesn't really stress me. It's just part of doing business."

(farmer at farm 6, personal interview, 11 September 2015) 
"I'm comfortable with the amount of debt that I have. We usually carry $\$ 150,000$ to $\$ 200,000$ worth of debt." (operator at farm 3, personal interview, 30 June 2015)

"It doesn't bother me at all. As long as I can service the loan payments." (operator at farm 3, personal interview, 30 June 2015)

The farmer used to share the discomfort with having debt. As his operation grew, however, he came to accept it.

"I used to really not wanna be in debt and now I don't give a shit at all. I just take out money whenever I need a piece of equipment. I borrow it and hope for the best."

(operator at farm 3, personal interview, 30 June 2015)

The statement that he "hope[s] for the best" implies that, for this farmer, debt is associated with a degree of risk that is beyond his control, even though it does not worry him.

There is a strong relationship between the readiness to borrow money and the scale of an operation. The smaller farms in this study tried to stay debt-free or keep it at a minimum, while the larger operations take out large loans to finance their business. The available data does not allow a conclusion to be draw about the direction of that connection. Does the desired scale affect the willingness to borrow or does the debt load a farm carries determine a certain scale in order to pay the debt? The facts that each of the interviewees seemed to be content with the amount of money they owe or not owe and none of them blamed their creditors for any decisions they had to make, suggest that the scale and debt load of an operation is indeed a matter of free choice. It should be noted, though, that the two farms with the highest debt have been successful in generating enough income to service their loans. Farmers that struggle to pay their debt payments did not participate in this study and may have a different view on the matter.

\section{8 "Never enough hours in a day": Small farms, big farms}

Size is an often-discussed dividing line used to characterize farms. Besides differentiating farms into large and small, these categories are also subject to lively debate about their contributions to the economy. In his famous book "Small is Beautiful", Ernst Friedrich SCHUMACHER (1973) makes a strong case for small, "appropriate" technologies, including farming methods. The most prominent champion of the opposite model was U.S. Secretary of Agriculture Earl Butz (1971-1976), who pushed farmers to "get big or get out." Theoretical discourse aside, what do agricultural producers in the Ithaca Local Market Area think of the scale of their operations?

Many of the research participants saw farm scale as a matter of individual choice between options with specific advantages and disadvantages. According to this view, finding the right scale is less about maximizing viability, but more about being able to practice a certain style of agriculture that aligns with the economic and moral expectations of each of the farmers.

"It's just two different things; everybody's got their own way of doing things, making things work." (farmer at farm 6, personal interview, 11 September 2015)

"You have to know how many acres you have to farm in order to provide you with the income that you want." (operator at farm 3, personal interview, 30 June 2015)

"You have to decide and really commit to large [or small] scale. [...] There is a tough decision to make - whether to scale up to bigger or to stay small [...]. There is both."

(farmer at farm 2, email interview, 11 June 2015) 
The interviewees pointed out strengths and weaknesses of small-scale and large-scale farms, respectively. The gardener made a case for small-scale agriculture, stating the quality of her products as a reason.

"The scale I have chosen gives me a higher quality product than someone who does it all on rows on a grand scale. My stuff is probably more vital.

I don't see any disadvantages. I'm pretty pleased."

(gardener at garden 1, personal interview, 14 May 2015)

The operator of farm 5 also highlighted the merits of small farming. Being small allows her to maintain strong connections to her loyal customers.

"Knowing your customers is an advantage. Having CSA member retention. We have pretty good retention rates with the CSA."

(operator at farm 5, personal interview, 17 September 2015)

Another strength of small-scale farming that she values is the opportunity to do much of the work themselves, without having to rely on external labor.

"I think our size allows us to accomplish most by ourselves. If we didn't have our work shares we could still do the work." (operator at farm 5, personal interview, 17 September 2015)

"I want to stay in a place where I am still touching plants and soil on a regular basis.

That's my favorite thing on a farm. I love planting. That makes me really happy."

(operator at farm 5, personal interview, 17 September 2015)

The farmer at farm 6, on the other hand, saw merit in scaling up. He valued the greater cash flow of a bigger operation, making necessary purchases of equipment more affordable. Still, he acknowledged the independence of small farms from expensive machines and, thus, investments.

"I think with smaller farms some decisions might impact you more, but a big farm is making six to eight million dollars a year, buying a couple hundred thousand dollar tractor isn't a big deal. With a small farm they're not going to do that, chances are they probably don't need something that big anyways." (farmer at farm 6, personal interview, 11 September 2015)

For him, having a bigger operation equaled a higher income. He implied the logic of accumulation: a large farm generates more income that can be reinvested in more means of production, resulting in even more income.

"I guess with a smaller farm you've got a smaller paycheck."

(farmer at farm 6, personal interview, 11 September 2015)

"It takes money to make money." (farmer at farm 6, personal interview, 11 September 2015)

This is in line with the reasoning of the operator of farm 3, who also appreciated the better cash flow for reinvestments and paying off debt.

"hav[ing] enough cash flow through the business to service debt to get better equipment and have enough acres to provide enough flow of product to make the whole thing pan out." (operator at farm 3, personal interview, 30 June 2015)

Economy of scale is another benefit of a large-scale farm, something this farmer valued:

"The advantages are perceived better cash flow and profit through more throughput of product and better utilization of the equipment you have. If you have a tractor and you spread it over more acres, the per acre cost goes down."

(operator at farm 3, personal interview, 30 June 2015) 
Another, related benefit of being a bigger farm is the ability to pay for extra labor.

"An advantage of a bigger farm is that you have got get to a certain scale in order to be able to afford a guy like our hired man and have some help"

(operator at farm 3, personal interview, 30 June 2015)

The operator of farm 3 gave a balanced perspective on being a large farm, listing downsides, too. For instance, he said that scaling up immensely increased his workload.

"I guess the disadvantage is that we always struggle to get it all done." (operator at farm 3, personal interview, 30 June 2015)

"When I think back when we were just growing crops and bulk marketing them, we had so much more time. I have like zero extra time now. 'Cause when I'm not farming I'm on the phone or I'm up there working with customers and doing all these other things. There's a cost to that. The cost is my free time." (operator at farm 3, personal interview, 30 June 2015)

Not enough time to get all the work done, however, is not only a constraint unique to large-scale farmers. The operator of the much smaller farm 5 also complained:

"There are never enough hours in a day, but I guess that would also be a problem if you were a more large-scale farm." (operator at farm 5, personal interview, 17 September 2015)

In addition, the operator at farm 3 mentioned that some land is not well suited for his large machines.

"Bigger equipment is helpful, but there are still the actual, physical logistics of getting from field to field that are always going to be a constraint for us."

(operator at farm 3, personal interview, 30 June 2015)

He also referred to the expensive investments in equipment typical for large operations as a disadvantage.

"We're trying to get the size and the modernness and the reliability of our equipment up to where it should be for the number of acres that we farm. Which is an expansive proposition." (operator at farm 3, personal interview, 30 June 2015)

This is in accordance with the thought process of the farm 2 operator, who added the cost of fuel into the equation. In contrast, he appreciated how high-end machinery can protect equipment and body from physical harm.

"Equipment is both an advantage and disadvantage. You have to decide and really commit to large scale: big expensive tractors with high fuel costs, or constant wear and tear on small tractors; i.e., on the body more physical on small farms."

(farmer at farm 2, email interview, 11 June 2015)

More generally, this interviewee saw the health risks associated with small farming as a problem.

"Staying healthy. It is hard, physical work." (farmer at farm 2, email interview, 11 June 2015)

Between the two extremes is a whole range of different scales that combine specific features of large-scale and small-scale farms. For many research participants, the goal has been to find the perfect middle ground for their ideal lifestyle.

"You've got to find the farm scale you are comfortable with. I think I am beyond that at this point." (operator at farm 3, personal interview, 30 June 2015) 
"It depends on what you're trying to get out of it. [...] I wanted to see if I could make a living farming and pull it off. [...] And that requires a certain scale."

(operator at farm 3, personal interview, 30 June 2015)

"As long we are at a scale where we are still doing some of the work, but maybe not all of it, I think this is where we are heading."

(operator at farm 5, personal interview, 17 September 2015)

The operator at farm 3 wondered if a medium scale would actually be more profitable than his 1200 acre (486 ha) operation.

"That said, it would be interesting to do some research about shrinking the operation back and see 'Am I really making more money?' There's a natural tendency to think 'more and more and more' and 'bigger is better' but I'm not sure if that's true."

(operator at farm 3, personal interview, 30 June 2015)

As stated in the beginning of this section, the research participants perceived the scale of a farm as something they can select individually. But do all farmers get to pick their scale according to their preferences? The operators of farms 3 and 5 expressed a desire to farm at a different scale, smaller and bigger, respectively. This suggests that there are forces that keep farmers from reaching their aspired scale. The exploration of these powers is beyond the scope of this thesis, but it is noteworthy that none of the research participants expressed that they feel constrained to farm at a different scale than they wanted to.

In conclusion, the research participants saw the scale of an agricultural operation as a matter of choice. In their opinion, both large- and small-scale farming have certain advantages and disadvantages that need to be balanced in a way to allow a specific style of farming that is in line with the operator's values and economic needs. Often, the farmers located that equilibrium somewhere in the middle of the two extremes "large" and "small."

As specified by the interviewees, strengths of small-scale farming are the higher quality of the products, independence from capital-intensive equipment, close relationships to loyal customers and a connection with the actual work on the land, the soil and the plants. Weaknesses are the hard physical work that strains the body and puts wear on small machines.

Advantages of large-scale farming, on the other hand, have been identified as affordability of extra labor, as well as higher profitability through better cash flow and economics of scale. Disadvantages are the large but necessary investments in machines and fuel and the fact that some land is physically not suited for big machines. And, as the operator of the 700-head dairy farm put it graphically:

"On a big farm you just have a lot of manure to deal with."

(farmer at farm 6, personal interview, 11 September 2015)

\section{9 "I don't know if I want my kids to be farming": Farm future and succession}

Coming from Europe, where kinship, especially patrilineal inheritance, determines decisions about farm succession, I was surprised that none of the interviewed farmers explicitly desired their children to take over the operation. Anyhow, the continuation of the farm in the future did not seem to be a prime concern for any of the research participants.

The three youngest farmers expressed that the succession of their operation does not worry them, even though it is on their minds.

"That doesn't keep me up at night, but I guess you never know."

(farmer at farm 6, personal interview, 11 September 2015) 
"[The question of farm succession is not] too important yet as I am still young, but it's in the back of my mind." (farmer at farm 2, email interview, 11 June 2015)

"It is not that important to me. Maybe I'll feel differently in 30 years." (operator at farm 5, personal interview, 17 September 2015)

For the older farmers in this study, succession of their farms was both a real concern and one they felt ambivalent about. Still, none of them has actively started to prepare for it.

"That is a good question. I don't know if I want my kids to be farming."

(farmer at farm 4, personal interview, 1 July 2015)

"It is confusing. I don't have a plan. I don't know where the good choice is. It sometimes feels it can be a burden. But I also see it as a gift."

(gardener at garden 1, personal interview, 14 May 2015)

"That is a good question. I don't know what's gonna happen to this place. Haven't really started looking hard for [a successor]."

(operator at farm 3, personal interview, 30 June 2015)

The farmers of the two biggest, participating operations wanted someone to take over the farm, regardless whether that person is a family member or not. The organic grain farmer, in particular, linked this desire with the commercial success of his business.

"I would love to have somebody, a young farmer, come and wanna take the farm over because I think it is a good farm, it is a profitable farm."

(operator at farm 3, personal interview, 30 June 2015)

The soon-to-be operator of the dairy farm, the successor of the current operators, also wanted the farm to continue:

"I don't see us shutting it down and selling the stuff and leaving, especially now that there are quite a few people [in their twenties] that are looking to get, to do some kind of farming." (farmer at farm 6, personal interview, 11 September 2015)

It seems like larger and financially profitable farms feel more inclined to find a successor outside the family, if none of their children aspires to take over the operation, than smaller ones do.

Asked whether they would consider selling their farm, the research participants replied differently. The gardener said that she does not want to sell her property, however, she did not have a plan what to do with it in the future.

"I don't think that I'll ever sell it." (gardener at garden 1, personal interview, 14 May 2015)

The operator of farm 4, in contrast, considered putting up his farm for sale when he retires:

"Who knows? I might sell it to my dad, he'd probably buy the land off of me and some of my equipment." (farmer at farm 4, personal interview, 1 July 2015)

The other farmers did not mention whether selling their operation is a conceivable alternative for them if they cannot find a successor.

Three of the interviewees were concerned about passing their farms or garden on to their children. They stressed the potential troubles that an inheritance can bring. However, they did not rule it out either. 
"I don't want to make my children feel it is their responsibility. I don't think that I'll ever sell it. But I also don't really agree with children inheriting stuff.

Sometimes it feels like a bigger burden to have something then it is a freedom to create something you can create. [...]

I guess it will belong to my children, but I also don't want to burden them. I'm not sure." (gardener at garden 1, personal interview, 14 May 2015)

"I would think, if we have kids and they don't wanna take over the farm, then they shouldn't. You should only farm if you really want to."

(operator at farm 5, personal interview, 17 September 2015)

The operator of farm 4 wished for his children to find a more secure occupation than farming, but would not be opposed if they were interested in continuing his operation, either.

"I don't know if I want my kids to be farming, it's a lot of hard work, a lot of hours, for not a lot of money. I hope they find something that is a little less strenuous on the body and where they can make more money so they are more financially stable than I am.

[...] I have two kids, if one of them wants to take over, I'm not gonna...you know...I'll tell them what's the deal with it. What they wanna do they wanna do. I can understand."

(farmer at farm 4, personal interview, 1 July 2015)

In summary, the interviewees had contradictory opinions about the succession of their farms. Some of the research participants wanted a young generation to take over the operation, whereas others were willing to sell it. Each of the interviewed farmers was open to the idea of finding a successor outside of their families.

\subsection{Economies of scale benefit large-scale farms to repair equip- ment and apply for support programs}

Two further advantages of large-scale farms became evident through the research that the interviewees had not identified. These are economies of scale that benefit larger farms when it comes to maintaining their equipment and applying for government subsidies.

Despite using bigger and more advanced machines, the large-scale grain and dairy operations that participated in the study are able to repair much of their equipment themselves, unlike the smaller farms.

Due to their scale, the two largest farms of this study can afford the necessary repair equipment, a workshop and the expertise.

"We have guys on our farm that can fix things, they're pretty good. They can fix most stuff." (farmer at farm 6, personal interview, 11 September 2015)

At farm 3, the operator, a trained mechanic himself, and his hired man do most of the maintenance and repair work on the farm themselves. It's only the newest tractors that they cannot mend due to their lack of specialized maintenance soft- and hardware that exclusively authorized workshops and dealers are allowed to use.

The smaller farms often do not have the expertise or time to do the repairs themselves.

"We have a tractor mechanic. [... ] There are too many professionals that are so good at doing that. We're not gonna try to be a mechanic. We decided to bite the bullet and pay the money.

I wish we were able to do more home-fixing. My partner made an effort to do more of that, 
but for the most part we just... We don't have the time for that. We both work off-farm jobs." (operator at farm 5, personal interview, 17 September 2015)

Some of the smaller farms try to do some of the repairs, but call in a mechanic for more complicated work. Some of the equipment ends up not being repaired at all.

"A lot of tools actually don't get fixed. The tractor is fixed by dad and his brother. The weed whacker gets also fixed by dad. The truck gets fixed by our neighbor who is also a mechanic." (gardener at garden 1, personal interview, 14 May 2015)

"We do our best or we call a welder, mechanic-champion welder, an Amish." (farmer at farm 2, email interview, 11 June 2015)

The observations suggest that large, more mechanized operations find it easier to allocate resources to maintain their equipment than smaller farms do, despite the latter using much simpler and straightforward machines.

Another area where larger farms are advantaged is their ability to apply for grants and other government subsidies.

Farms 3 and 6 receive money through the ARC and PLC commodity programs, NRCS conservation and stewardship programs, the Environmental Quality Incentives Program (EQUIP), funding for laneways and storage and co-funded investment grants. On the other hand, the only scheme that any of the other farms took part in was a high tunnel grant received by farm 5 .

Two of the vegetable producers, farms 2 and 5, considered registering for government programs an annoyance. There is also a lack of knowledge about applicable grants.

"I don't think anything applies to us, but I also haven't really looked into it. I don't know anything about them, really." (operator at farm 5, personal interview, 17 September 2015)

That is in stark contrast with the opinion of the grain farmer, who found applying for money easy:

"They [the government] don't make it big hassle. They try to help you along. They want you to apply. They want you to participate in it. They want farmers to be good stewards. The money is there. The guys at the NRCS office here are really helpful and smart. [...]

I find it very easy to be part of these programs. They make it easy."

(operator at farm 3, personal interview, 30 June 2015)

For him, it is particularly simple because he has gained a good reputation with the NRCS. Often, the government officials approach him to apply for a certain grant:

"They are always kind of after me to enroll in these programs because I have that mind set already and if I sign up I will actually implement it, whereas with a lot of other farms, the NRCS is after them with the stick trying to get them actually do what they have signed up to do." (operator at farm 3, personal interview, 30 June 2015)

This statement indicates that it is easier to obtain subsides once you are familiar with the procedure and the responsible officials.

The operator of farm 3 was mostly interested in conservation-oriented programs, because they award money for agricultural practices that he is doing anyway, out of principle.

"The government will pay you a certain amount to participate in these things [conservation practices]. Now these are things I will do whether the government will pay me for that or not. But if they're gonna give me money I can take it to do good. [...] Those programs I really try to participate in because I feel like they are really having an impact on everybody, not just me." (operator at farm 3, personal interview, 30 June 2015) 
Despite that, he also applies to suitable programs that he disapproves:

"The just straight-out crop payment programs I think are bullshit. But if they're gonna give to me, I take it." (operator at farm 3, personal interview, 30 June 2015)

In the same way, farm 6 tries to make use of all subsidy schemes that are relevant to them.

"We try and take advantage of the stuff we pay our taxes for. If there's something that we're doing and there's money out there, we try to apply for it."

(farmer at farm 6, personal interview, 11 September 2015)

Economies of scale applies here, too. The larger a farm, the larger the sum of money available through a specific program, while the expenditure of time to educate oneself about the schemes and to fill out the appropriate forms increases at a much slower rate. That is, the more complicated the application procedure of a support program is, the more systematically disadvantaged small farms are.

To conclude, the interviews suggest that the larger an operation, the easier it is for them to sign up for government-funded programs, grants and subsidies. This is largely due the economies of scale, since the application effort decreases relatively per dollar received with increasing farm size. Applying gets even less demanding with more experience and when a farm has a good reputation with the official agents in charge. Likewise, large-scale farms find it easy to allocate on-farm resources to maintain their equipment than smaller operations do.

\subsection{1 "Not a lot of land that's sitting": Access to land}

As shown in chapter 2.3 (Farming sector), the value of farmland has increased by $64 \%, 84 \%$ and $96 \%$ in Tompkins, Schuyler and Seneca Counties, respectively, over the past years. This rise is an indicator for the desirability of land in the Central Finger Lakes Region. While landowners profit from this trend, it causes problems to farmers who aim to extend their acreage. It is even worse for people who want to start farming and do not have much financial capital to begin with. What is more, landowners seem to hold on to their property. As a result, there is little land available on the market. For this reason, the discontinuation of farms is a chance for others to get more land. One interviewee explained:

"I don't think farmers want to see other farmers go out, but if they do then it's an opportunity for them. If other farms nearby are going out of business it kind of helps us, in terms of land availability [...]. Right around here in this area there's not a lot of land that's sitting, farms going out of business haven't sold to somebody else."

(farmer at farm 6, personal interview, 11 September 2015)

That development causes farmers to compete for land. For example, farm 3's growth from a small vegetable farm to a 1200-acre (486 ha) operation led to tensions between the operator and their neighbor:

"In a lot of rural communities, all these guys are competing with each other for land and they get into little fights. Like me and my neighbor, we don't talk at all."

(operator at farm 3, personal interview, 30 June 2015)

The operator described how capital-intensive farms are at an advantage when land is for sale. Further, they may offer higher prices to a landowner and take over someone's lease; a practice the grain farmer called theft.

"There are a lot of really big farms around that are just swallowing up everything. In our area there are two giant dairy farms. [...] They are so big and they have so much money that they 
can outbid anybody on any piece of land. They will come in and offer your landlord more money than you did and steal your land away. They don't give a fuck. They're just taking everything.

It will affect me. It is starting to. They just build a 4000 cow dairy down the road and they'll probably start coming up here and trying to steal land away from me."

(operator at farm 3, personal interview, 30 June 2015)

Especially beginning farmers struggle to afford land for their start up. For instance, the wwoofer of the garden identified the lack of access to land as one of her main obstacles in realizing her dream to become a subsistence farmer. The operator of farm 3 explained:

"It makes it difficult for anybody else to come in and farm anything. How can you compete against that guy? If they were here when I was trying to start I would have never started." (operator at farm 3, personal interview, 30 June 2015)

Against this background, the farmers of this study use different strategies to gain access to farmland.

Only the gardener and the operator of the dairy farm inherited land from their parents. While that has been enough for the former, the latter has bought more and more land during the last decades, which is another common, albeit expensive way to extends one's acreage. Other farmers have bought land, too, but much less. Farms 3,4 and 5 have purchased 40 acres (16 ha), 47 acres (19 ha) and 19 acres ( $8 \mathrm{ha})$, respectively, while the dairy farm now owns 1300 acres (526 ha). This is in part due to the contrasting scales of the operations, but also a result of two different strategies. As way of illustration, farm 3 is a large organic grain operation on 1200 acres, but owns only 40 acres of that and rents the rest. Leasing is another widespread way how farmers secure their land base. Besides farm 3, farms 2, 3 and 6 have also leased. Unlike with purchasing, where the price is largely determined by its appreciated value, the conditions of a lease vary widely. Farm 2 has rented their land from their parents, the other farmers from various proprietors. Farm 3 has been able to rent a lot of land under favorable conditions, sometimes even for free, since the landowners regard the operator as a good steward.

"A lot of the people that are renting me land rent me the land because I'm an organic farmer and they like what I'm doing. They think what I'm doing is the right way to farm and the right way to take care of their land. They not want to have these guys come in with their giant liquid manure spreader and blast the shit out of their land.

I just can't say no if someone says 'Oh, I've got 100 acres. Do you wanna farm it?'" (operator at farm 3, personal interview, 30 June 2015)

Farm 5 managed to lease land for free, because their landlord needed someone to take care of it. Before they started at their current location, they were able to farm for free while they were looking after the property owned by a couple who had moved out of town for a few years. The operator suggested trading work for land as a practicable way to start farming:

"When we were leaving Cape Cod, my partner said I never want to pay rent again and I thought 'you are crazy; that is impossible.' But we have never paid rent ever since then. If you are willing to work in exchange for rent, there are people in this area that are willing to work for you, if you look twice."

(operator at farm 5, personal interview, 17 September 2015)

This was seconded by one of the workers at farm 4, who cultivates some land for free in exchange for yard work at the property where he lives. The gardener also uses some land that she does not own for free. Her mother lives next door and lets her use some of her property without having leased or passed it on to her.

The Groundswell Center for Local Food and Farming and Cornell Cooperative Extension of Tompkins County have initiated the Finger Lakes LandLink program, a platform for landowners and landseekers to connect and to facility these kind of unconventional arrangements. 
Finally, working on someone else's operation is a way to start farming for people who do not have access to land they can control themselves, as the wwoofers and farmworkers exemplify. Their liberty to use the land for their own needs is at the discretion of their host or employer. Farmworkers usually have to perform the tasks they are assigned, but wwoofers sometimes have more freedom to decide what to do, depending on their host. The wwoofer at the garden, for instance, said that she could do own projects on the land if she wanted to.

In summary, the surge in land prices has increased struggles over land among the farmers. Financially strong operations are able to take over someone's lease and find it easier to buy land. However, sometimes landowners prefer to rent their property to farmers who they regard as better stewards, even if they pay lower or no rent at all. Some farmers have gained access to land as part of a work exchange, looking after someone's property. Inheritance is a common way to obtain land for people whose parents were landowners. Some land is used on an unwritten agreement with the owners. Finally, landless workers resort to working or volunteering on someone else's operations to farm themselves. 


\section{Agrarian change}

\subsection{Subsistence-oriented farming as social struggle}

The farms that participated in this study are oriented towards being subsistence operations, despite being integrated in the capitalist framework of the society at large. Or as VAN DER PLOEG $(2013,3)$ puts it: "being embedded in (and subordinated to the overall logic of) capitalism does not imply that all agriculture is capitalist agriculture." The observations revealed that the intrinsic condition of their production is geared towards their own subsistence, whereas extrinsic conditions force them to sell and buy commodities and make a certain minimum profit to pay their dues.

The love of good and healthy food, working outside, the pride in feeding others, the rewards of hard, physical labor, a feeling of responsibility to the environment and social equality and farming as a way to make a living, among others, were commonly stated as motivations why the farmers had chosen their occupation. These motivations show in their production. Chapter 5.2 (Self-sufficiency and cosufficiency) showed that many grow their own food, they maintain an informal trading economy to increase co-sufficiency, they actively build social relationships of mutual support, and they help one another to create a community where they too can get help when they need it. They provide family, friends and customers (that they often personally know) with food, they try to be good stewards of the land, and in fact work hard to live off the land. In varying ways and to different degrees, the farmers of this study orient their production towards their subsistence.

Subsistence-orientation in a capitalist world does not mean pure subsistence production. It means to strive towards a life that is more strongly connected to subsistence, which entails struggle against the institutions that seek to exploit farmers for their interests. When, for example, the agricultural producers of the Ithaca Local Market Area build a network of mutual support and provisioning, they reduce their dependence on commodity market solutions. When the farmers try to be good stewards of the land, they perform what VAN DER PLOEG $(2008,24)$ calls the co-production of men and living nature, which include production for consumption and reproduction. He sees this development of agriculture and resource base as a fundamental element of the emancipation of the peasantry.

Limitations in subsistence production are not a matter of free choice by the producers, but the result of actions by the institutions of capitalism against the autonomy of farmers as part of the war against subsistence (ILLICH, 1982; cf. chapter 4.2 Subsistence perspective). These actions include the enforcement of rent, debt and tax payments, the protection of unevenly distributed private property on means of production and various legal regulations and standards.

The focus on subsistence in the self-controlled sphere of production, as well as the struggle to extend that sphere, indicate that the interviewed farmers are oriented towards subsistence, despite all contradictions imposed by extrinsic conditions and internalized capitalistic patterns of behavior.

\subsection{Repeasantization in the Central Finger Lakes}

Agriculture in the Central Finger Lakes Region is determined by repeasantization, that is, an increasing number of farmers orient their economy more strongly towards the principles of peasant farming. Against pressures to industrialize, repeasantization manifests as a struggle, as "a modern expression of the fight for autonomy and survival in a context of deprivation and dependency" (VAN DER PLOEG 2008, 7).

This fight takes various shapes. Perhaps the most basic is the improvement of a self-controlled resource base that provides the foundation for autonomy. There are two ways to do that: The first is to seize or create means of production to integrate them into the economy of the farm. Depending on the level of control, this allows them to be used for one's own subsistence needs and exclude them 
from the logic of the capitalistic market. This is the route taken by farm 5 , which had bought new land to scale up their operation. The second way is to enhance the quality of the resource base already held by a farm. Farm 3, for example, plans to extensify its production and focus on cover crops to regenerate and build up the soil. Farm 2 wants to extensify much of their land to be able to use less land more productively. The garden also focuses on the improvement of their land instead of growing in size.

The struggle towards more subsistence production described in the previous chapter is another feature of repeasantization. Although the state imposes ever more obligations to align agricultural production with the so-called laws of the market (which, in reality, are laws of the capitalist state), including commodification, competition and expansion, farmers defend, rebuild and extend their sphere of subsistence production.

Another indicator of repeasantization is the farmers' establishment of a community-controlled economy that is in opposition to the capitalist market economy. As chapter 5.3 (Community and cooperation) has shown, this includes informal trading, giving and taking based on generosity and reciprocity, money-based transactions that are based on personal social relations, and production for cosufficiency. This allows farmers to distance themselves from the capitalist market economy to meet many of their immediate needs in self-controlled and culturally appropriate ways. An indicator of the strengthening of this community-controlled economy is the growth of the Ithaca Farmers' Market and the steep increase of CSA shares in the area.

"Co-production of men and living nature" (VAN DER PLOEG 2008) is another common theme of the peasant condition that can be observed in the Ithaca Local Market Area. As explained in chapter 4.4 Approaching the peasantry, this covers the production of consumer goods and services (for sale or self-use) and the production of the farm's own resource base, including natural and social resources. Goods and services are the most visible outputs of production. It comprises the foodstuffs, inputs for other farms such as seeds and manure and other raw materials, as well as labor and processing services that are sold and accounted for. It is this part of the production that figures in the biennial USDA Census of Agriculture. The subsistence production for the household, as well as products and services for trade or to give away also fall into this category. On the other hand, the farmers that participated in this study also work to produce their resource base, with the ultimate goal of preserving and improving it for future use. One element of producing the natural resource base are the various ways of land improvement mentioned earlier in this chapter. It also includes soil-conserving cultivation techniques that restore the fertility of the soil. Farms 2, 3, 4 and 5 explicitly mentioned that they use organic cultivation methods for their positive environmental, conserving effects. The garden takes special care of pollinators, a living resource that agriculture depends on. One of the reasons why farm 6 transitioned to organic was their concern about overuse of pesticides. In terms of reproducing social resources, the farmers actively build a supportive community, both on the farm (see farms 1 and 2 in particular) as well as beyond (cf. chapter 5.3 Community and cooperation). Again, this co-production takes place as a means of increasing autonomy in order to shape one's lives more according to the intrinsic condition, one's own values and goals.

Another point that indicates repeasantization is the focus on labor-driven intensification on four of the six studied farms. Operations 1, 2, 4 and 5 mainly rely on hiring more workers or attracting more volunteers if they choose to increase their production. This intensification leads to quantitative repeasantization, because it allows more people to work and live on the land and learn the necessary skills to become farmers. While it could be argued that this is a process of proletarianization instead of repeasantization (people get hired as rural laborers instead of beginning their own farms), it offers a chance for people to gain experience with farming and acquire the skills and sometimes financial capital necessary to start an own farm. The interviews with wwoofers and farmworkers suggested that this is the chosen route for at least some of them. Part of the increased sales on farm 3 also happened through more labor, when the operator began to concentrate on direct marketing, accepting the higher workload associated with it.

These four activities, improvement of the self-controlled resource base, struggle towards more subsistence production, establishment of a community-controlled economy, co-production of men and 
living nature and labor-driven intensification show that repeasantization is a development trajectory of agriculture in the Central Finger Lakes.

VAN DER PLOEG (2008) distinguishes qualitative and quantitative repeasantization and it should be noted that the previous discussion has only touched the former. Quantitative inquiries of repeasantization require extensive data collection that go beyond the U.S. Census of Agriculture and that were impossible to carry out given the available resources for this thesis. A great part of repeasantization takes place on the fringe of agriculture: people that start a homestead, a backyard garden or a small farming operation on someone else's farm, et cetera. These operations often fall below the farm threshold set by the USDA and are thus not counted in the census. Yet, they can be both starting points for new farms with a focus on peasant agriculture as well as manifestations of peasant farming in their own right.

Regardless, between 2007 and 2012, the number of farms in Tompkins, Schuyler and Seneca Counties has increased, particularly small farms with less than 10 acres (4 ha; see chapter 2.3 Farming sector). The data does not imply what kind of farming (peasant, entrepreneurial or corporate farming, or a combination of these) these new farms practice or aspire toward; however, at least, this trend suggests that livelihoods on the land are becoming attractive again, after years of rural depopulation.

Repeasantization is not the only agricultural development in the Ithaca Local Market Area. Many farms continue to industrialize, while others discontinue operation. However, this trajectory is met with a counter-development of repeasantization that is gaining momentum.

\subsection{Pockets of peasantness as seeds for a life beyond capitalism}

Capitalism as the hegemonic social regime is in crisis. It suffers from serious flaws that threaten its continued existence. Be it environmental "limits to growth" (MEADOWS 1972) that are about to cause a "peak everything" (HEINBERG 2007), climate change as a result of the extraction and dumpbased industrial production or increasing social inequality that is challenging its entitlement to provide prosperity for everyone; there is reason to believe that capitalism will collapse unless it finds a way to overcome these contradictions. There is also a widespread notion that this will be impossible because these problems are inherent. Jason MOORE (2014), for instance, argues that capitalism is likely to end because it cannot continue its strategy of expanding its resource frontiers through new enclosures because "capital's demand for cheap natures rises faster than its capacity to secure them" (ibid. 288). For him, the crises of the early 21 st century - food, climate, finance, and energyare "manifold expressions... of capitalism as a way of organizing nature" (ibid. 290). Naomi KLEIN (2014) insists that if humankind is to find a way to overcome the climate crisis, it will have to abandon capitalism. Therefore, there either will be a future without capitalism or there will not be a future at all that holds prospects of a good life for anyone but a small elite.

Consequently, it is time for a better alternative to be put in its place. This thesis has shown that the peasant economy is an alternative, subsistence-oriented way to meet the material needs of communities that is practiced by farmers today in the United States. ${ }^{1}$ Compared to utopian models, it is an alternative that is alive, that can be empirically studied and whose contradictions and struggles provide lessons for the transformation of society at large.

The peasant economy consists of principles that are highly relevant to economic sectors outside of agriculture. It is likely to gain in importance in a post-capitalist society and might thus be attractive for people who are not farming at the moment. Let me discuss these two points in detail.

First, the peasant economy consists of elements that can be applied outside of agriculture. Chapters 5.2 (Self-sufficiency and co-sufficiency) and 5.3 (Community and cooperation) have shown that farmers in the Central Finger Lakes focus on cooperation and reciprocal provisioning to provide for their needs and that their community is carried by mutual economic reliance. That is in stark contrast with the principle of competition that is one of capitalism's core ideological pillars and whose isolating effects can be felt in any corner of society. However, the informal trading and gift economy, as 
well as the networks of mentorship and mutual learning are powerful reminders that solidarity is possible. There is no conceptual reason why this moral economy should be limited to farming communities.

Another aspect in which peasant farming can be a model is its role in the struggle for autonomy. According to VAN DER PLOEG (2008), emancipation from capital is achieved through the development and improvement of a self-controlled resource base. This is similar to the idea of worker's struggle to seize the means of production to gain control over the productive process and to be emancipated from the exploitation of capital. Yet, farmers who control their land, seeds, water and other components of their production are advantaged in this respect, because only means of subsistence production allow for autonomy. Commodity producers still depend on the market to sell their products and to buy commodities for their subsistence, even if they are in full control of the production process. VAN DER PLOEG (2013) argues that "[w]ith a further unfolding of peasant agriculture the possibilities for self-government might be rolled out over far larger areas of social life." This understanding raises the cross-sectoral question of how the means of subsistence should be (re-)distributed for people (including non-farmers) to live more autonomous lives.

In addition, the peasant economy is directed towards subsistence. Hence, it constitutes a counternarrative to capital's "war on subsistence" (cf. chapter 4.2 Subsistence perspective). Subsistence production is more suited to staying within the limits of nature and an equitable society than capitalism's ever-expanding, accumulation-oriented production, especially when the needs of nature and the community are included in one's understanding of subsistence. Subsistence production is not limited to peasant farms. It is the foundation of social relationships in cities as well. However, it would appear to be more accommodating to carry out a livelihood in rural spaces than in an urban environment, where possibilities for subsistence production are more limited. Here, some key lessons from studying peasant farming can be: How can control over one's subsistence be extended into the city? Which non-rural forms of subsistence production can be (re-)claimed and how can they be integrated into a wider network of co-sufficiency?

What is more, VAN DER PLOEG (2013) suggests that peasant-controlled markets are better suited to meeting the needs of both producers and consumers than the hegemonic commodity markets:

"[Today's markets] are extended and rigid systems for making commodities flow in specific ways. The major features of these market systems include articulated centre/periphery relations, command centres that exert control-at-a-distance over extended spaces and large areas of social life, multiple sets of dependency relations, and a centralized appropriation of the generated value added. In contrast to these features, the nested markets that are emerging in many places represent an emerging alternative that goes far beyond their current mechanics and impact. Nested food systems are the equivalent of smart grid systems which offer a promise for energy production and consumption and their interrelations. They are locally centred but can be mutually connected whenever the need to do so arises. They are also flexible, have low losses and high efficiency levels. Above all they offer the promise of including and benefiting more than just small minorities of producers and consumers (as is currently the case). They have the potential to include all producers and all consumers."

(VAN DER PLOEG 2013, 21)

This can already be observed in the Ithaca area. Efforts are taken to facilitate and further subsidize food stamp receivers at the farmers' markets and GreenStar to give low-income consumers access to high-quality, locally produced food. Left-over food at the markets and CSA-shares from some farms are donated to local charities to avoid food waste and to support people who otherwise could not afford to buy at the market. This is not to say that a food stamp and charity-based system is the best way to solve the problem of hunger and malnutrition in the United States - an issue beyond the scope of this thesis. The point here is that the local farms and distributers are committed to providing the local community with their products beyond themselves and affluent customers. On the producer side, local artisans, street-food vendors and artists are included at the farmers' market, while the network of mutual support and economic relations described in chapter 5.3. (Community and cooperation) extends to local food-processing businesses, retailers, restaurants, mechanics and 
other associated trades. This shows that the rationale of the peasant economy affects markets in which not only farmers participate.

The second argument for the transformative potential of the peasant economy beyond agriculture is that it attracts people from other sectors who are not farming at the moment but might be in the future. In the so-called developed countries, the marginal share of agricultural producers of the total population is the result of the "get big or get out" development paradigm that laid the foundation for the accumulation of capital in agriculture and provided "cheap labor" (MOORE 2014) for the industry. With the end of capitalism, however, this trend is likely to reverse.

Many studies (for example, VAN DER PLOEG 2013, ROSSET 1999 or BADGLEY et al. 2007) showed that labor-intensive, peasant-based agriculture is best suited to producing and distributing enough and appropriate food for the increasing global population. That is, repeasantization has to be a major development trajectory of the future if humanity wants to stop hunger and starvation. (This question alone is so important that peasant agriculture, with its capacity to feed the world, should be a concern for entire societies.) Even today, peasant livelihoods are attractive for many who do not have access to land. This is the most articulated in the Global South, where agrarian movements (most popular the Movimento dos Trabalhadores Sem Terra in Brazil) fight for land for landless people to secure their subsistence and survival. But also in countries of the North people struggle to gain access to land for a farm, homestead or a garden. Chapter 6.2 (Repeasantization in the Central Finger Lakes) demonstrated that repeasantization is a current trend in the Finger Lakes Region of New York. Hence, part of the transformative potential of the peasant economy for the society at large is its capability to trigger repeasantization that is attracting wage-laborers to move to the land to live more subsistence-oriented and more autonomous lives.

The peasant economy is not a blueprint for the post-capitalist society. Yet, if adapted to the specific circumstances of society's many facets, it is a source of inspiration for a subsistence economy that is fit to replace the hegemonic maximization economy as a way of organizing human-human and human-nature relations as capitalism fails to deliver on its promises. Rather than dismissing peasants as backwards objectors to progress, their struggle for autonomy should be understood as one of the last fights against the total hegemony of capital. Despite massive assaults on their way of living, millions of peasant farms continue their operations (ETC GROUP 2009), while other livelihoods are almost entirely under the control of capital. Similarly, it is wrong to dismiss Western, entrepreneurial farmers as accomplices of capital, while they struggle to navigate between coercion to follow the rule of the state (cf. chapter 4.5 Intrinsic and extrinsic conditions of farming) and desires to become more autonomous. There is no need to invent a post-capitalist utopia while existing alternatives falter, in part due to a lack of solidarity. Instead, we should make common cause ${ }^{2}$ with farmers to defend and extend the remaining pockets of peasantness as seeds for next year's sowing.

\footnotetext{
${ }^{1}$ As it is in many other parts of the world, albeit in varying, locally grounded manifestations.

${ }^{2}$ A powerful example for this common cause is the concept of food sovereignty that unites consumers and producers in a shared struggle for local control over food production. As McMICHAEL (2013, 4) notes, it is movement not just about food but about "re-envisioning the conditions necessary to develop sustainable and democratic forms of social reproduction. That is, the advocacy of farming rights is framed within a broader vision of how to rethink the ecological conditions and scale at which human communities can live, and survive."
} 


\section{Appendix A: Description of farms}

\section{Farm 1: Garden for self-sufficiency (17 acres)}

\section{Summary}

This operation is a family home garden geared towards self-sufficiency with vegetable beds, an orchard and chickens. It is run by a young woman in cooperation with her retired father. Supported through off-farm income, the garden provides food and a beautiful environment for her family, one wwoofer and guesthouse tenants.

\section{Location and size}

The family's home is based in a very hilly and forested section of the area under investigation. It is situated along a minor country road, with a few farms and residential homes scattered along it.

The family owns 4.5 acres ( $1.8 \mathrm{ha}$ ), but is able to use approximately another 12.5 acres ( $5 \mathrm{ha}$ ) that belong to the operator's mother, who lives next door.

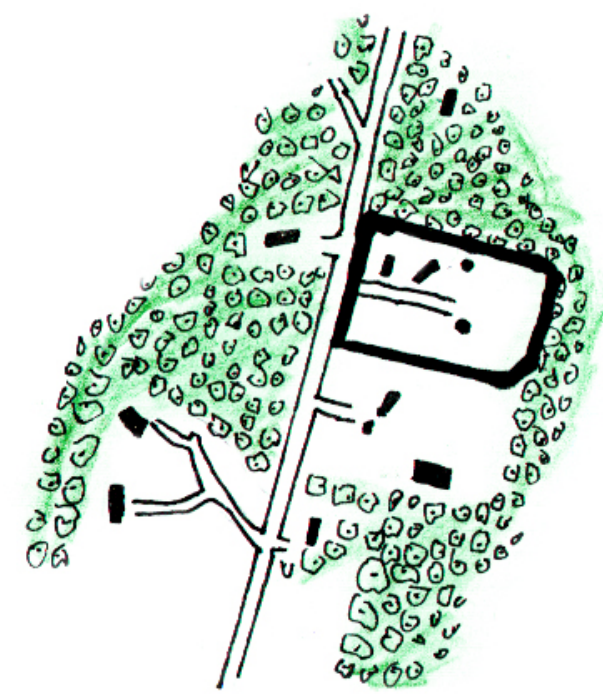

Figure 5: farm 1

\section{History}

While originally part of the homeland of the Cayuga Nation, the area around the farm was first settled by Finnish immigrants in the early 19th century. It was not until the end of the same century that the road that now serves the farm was built up with buildings; the farm's neighboring house being the first on the road.

The operator's parents bought the land in 1973 from potato farmers. They kept a garden in the backyard and a number of horses because the mother used to be a competitive barrel racer. They also kept a cow for a year. That was despite her father's will to never have a cow again after spending his childhood working on several dairy farms as a migrant worker and being fed up with that work. 
Even though the current operator did not get involved much in the gardening as a child and teenager, she and her sister started a small, commercial farm on the property and sold their products at the farmers' market and through a CSA.

Only two years later, they stopped the operation again when the current operator moved out of state. Having a return to the farm in the back of her mind, they established an orchard around that time. Over the course of the next four years, more trees were planted whenever the operator returned to the farm.

In 2007 she returned to the farm as a mother. She then re-established the garden, which became her primary focus. It was around that time that they built a new house to live in. The old family house has been rented out since. The same year, she started an education program to teach gardening to children. They started to harvest fruits from the orchard around 2010.

\section{Built environment and spatial organization}

The family lives in a three-story dwelling that was built after the current operator moved back to the farm. It is now equipped with a large array of solar panels. It sits on a slope along another slope right next to the driveway. One door can be reached directly from the driveway, another door leads to the garden, which is enclosed in netting wire to fence out the deer. About 0.2 acres $\left(830 \mathrm{~m}^{2}\right)$ in size, the vegetable and ornamental garden is tucked between the driveway to the south, the house to the west, a grove to the north (which also demarcates the property boundary) and a section of the orchard to the east. The garden consists of different parts. The section right next to the house is dominated by ornamental perennials and herbs, as well as a small pond. On the other side to the east, there are a number of rectangular beds used to grow vegetables. The end to the grove is used for composting green waste. The garden includes a circular yurt of roughly $30 \mathrm{ft}(9 \mathrm{~m})$ in diameter, which is used as a guesthouse. It has two entrances with a terrace each. One leads into the garden, the other to the orchard.

The rest of the garden is open lawn with occasional plantings of berry shrubs. Next to a small gate, which connects the garden to the driveway, stands a wooden shed to store tools.

The other side of the driveway is dominated by the orchard. It consists of various fruit trees of varying age pruned as standards or bushes, the lawn underneath is kept short. It is about 0.6 acres $(0.25$ ha) in size. Besides producing fruit, the orchard is also used as a playground for the children. To that end, playground equipment such as a swing and a slide had been installed.

Among the trees used to stand a large polytunnel. After being used as a storage facility for a long time, it was torn down during the fieldwork of this study. Tenants of the guesthouse use the remaining gravel as a parking area.

The southern end of the property is demarcated by another fence. Chicken live in their coop along this fence. East of the orchard, at the edge of the neighbor's pasture, a new one-story, octagonal guesthouse building is in the making. To the western end of the property, between the family's house and the road, stands the original two-story farmhouse, which is now rented out.

\section{Social organization and labor}

The family consists of the owner of the property, a woman in her thirties, her two young children, and her retired father.

The female head of the family extends the traditional understanding of a family as a group of individuals connected through kinship or marriage by including others, for example, her wwoofers. In addition to the family, guesthouse tenants live on the farm most of the year. The owner expressed a wish to further broaden the number of people who benefit from the garden by turning it into a community.

The woman works full-time off-farm to provide the financial foundation for the family and the garden. She expressed a concern to reduce work hours off-farm. 


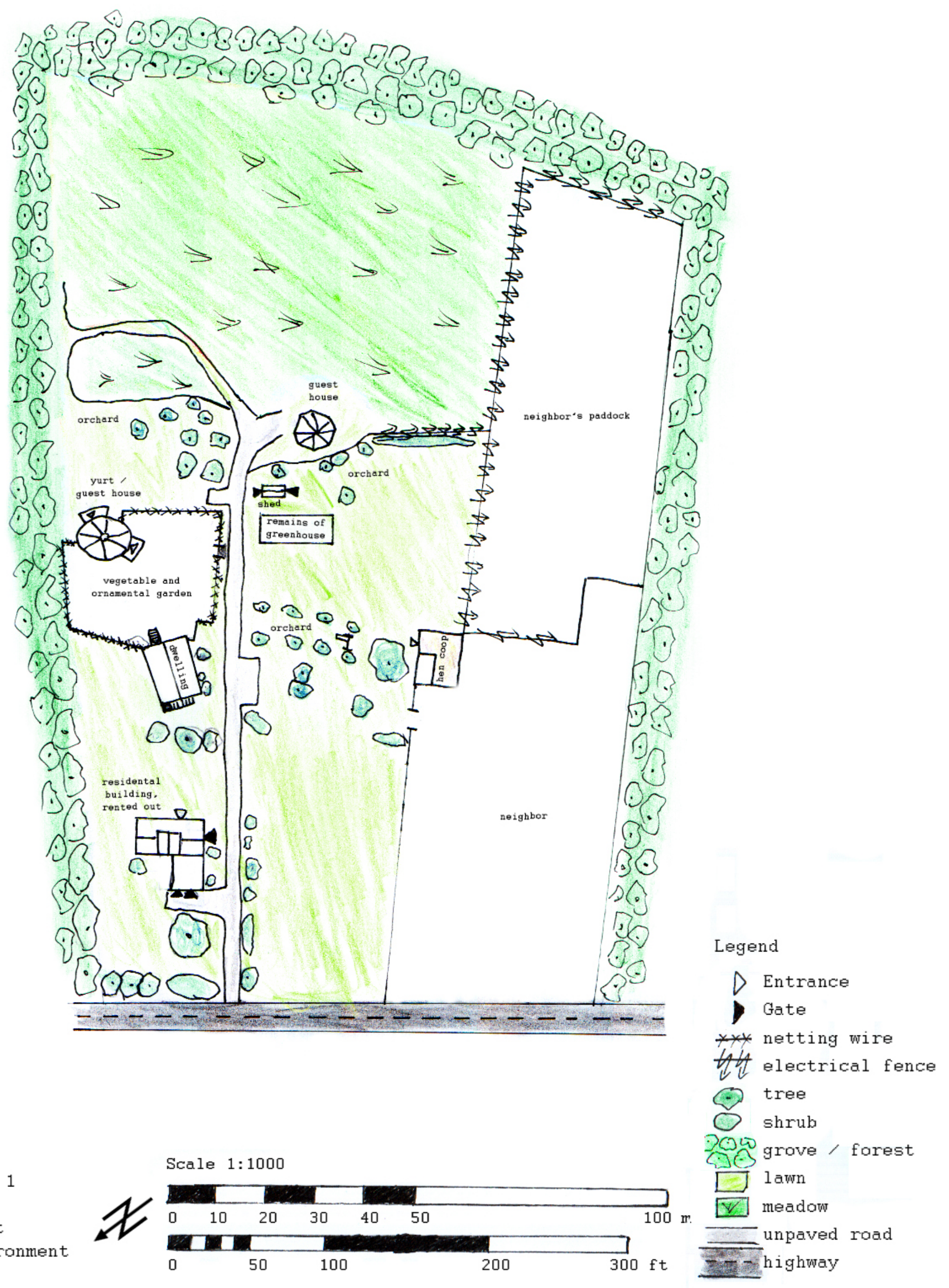

Farm 1

built

environment

Scale 1:1000 
Her father, a retired migrant dairy farmer and factory worker, assists her in the garden. He does the bulk of manual and routine labor, such as cleaning the pond, mowing the lawn, bringing bulky waste to the landfill, et cetera. He also helps out caring for the children and drives them to school.

Usually, she gets additional help from long-term wwoofers. At the time of this study, a 25-year-old woman from New York City with a bachelor's degree in Conservation Biology was staying on the farm for several months. However, they agreed that she could work a few days a week in the garden of the operator's sister in Ithaca. The woman had quit her office job in the winter to learn more about farming. She expects to volunteer on farms for three to four years to learn the necessary skills to become a subsistence farmer, a future career she finds intriguing. She chose to volunteer at this farm due to its proximity to Ithaca.

The children sometimes assist their mother in the garden, especially with weeding or watering. They are still very young so their physical contribution is limited. However the mother attributes the successful growing of her plants in parts to her children's "kid power."

"I feel they [the children] have some special powers in their fingertips and spirits to make the plants grow more successfully." (gardener at garden 1, personal interview, 14 May 2015)

On the other hand, she does not want to urge her children to work in the garden unless they want to. She fears that would ruin her children's attitude towards gardening.

The owner expressed mixed feelings towards the future of the place, especially towards succession. She feels inheriting property can be a burden. On the other hand, she does not want to sell it, and thinks she might pass the home on to her children despite her concerns. She also considers moving abroad and only returning to the farm sporadically, while someone else takes care of the property.

Decisions regarding the garden are made by the owner in agreement with her father. When it comes to the tasks of the wwoofers and the children, decisions seem to be made by consensus.

\section{Economical organization}

The garden and the orchard are geared towards production for subsistence. The products of the garden combined with commodities she buys at the grocery market satisfy the food needs for herself, her two young children, and her father and guests, including wwoofers who happen to be on the farm.

The gardeners grow a wide range of vegetables, herbs and fruit throughout the growing season for home-consumption on a very small scale. They also keep a flock of chickens for eggs. In the summer about $50 \%$ of their food demand is covered by the farm's own products. In the winter this number decreases to $15 \%$ or less. Preserving for the winter is very time-consuming and can often only be done with additional labor from wwoofers. The farm products are supplemented with products bought at the grocery store. While the operator would like to live entirely off her land, she also appreciates the opportunity to be able to buy food and other products and not having to rely fully on her own garden.

Additional income is generated through the letting of the yurt, which is occupied around $70 \%$ of the time throughout the year. Upon completion, the octagonal building is supposed to be rented out to tourists as well. Further income is generated by the long-term letting of the old farmhouse.

Another production target is the beauty of the garden. To some extent, the garden is commercialized, because it attracts tourists renting out the yurt. In any case, the garden is just as enjoyed by the family itself.

The gardener saves some of her seeds for propagation and allows plants to self-sow, but most of the seeds are purchased every year.

The family does not participate in any government program, nor does it receive any subsidies. 
The gardener did not take out any loans to invest into her operation. Her father, however, purchased his truck and the lawnmower through a zero-interest loan offered by the seller.

\section{Cooperation with other farmers and the community}

The family does not cooperate much with any of the surrounding farmers, homesteaders or gardeners. However, some tools are shared with neighbors. They are not members of any professional organization. However, the WWOOF network is valued as a valuable support resource.

\section{Equipment}

Only hand tools are used for cultivation. The father uses a weed whacker and a lawn mower. They use the father's pickup truck to move heavy things such as mulch, bales of straw or waste. 


\section{Farm 2: Community-driven vegetable farm (30 acres)}

\section{Summary}

This farm is a diverse vegetable producer, run by two young brothers in addition to their family and six wwoofers. On 10 acres (4 ha), they grow a large number of vegetables and fruit for their own consumption, as well as for sale through direct marketing.

\section{Location and size}

This farm is situated in a very rural area of the Finger Lakes Region, about 45 minutes outside of Ithaca. Despite the next neighbor being only $500 \mathrm{ft}(150 \mathrm{~m})$ away, it is a farm in a secluded, detached location.

The operators lease 30 acres (12 ha) from their parents, of which they have 10 acres (4 ha) in operation. The remaining 20 acres ( $8 \mathrm{ha}$ ) are mainly woodland, that is, currently left fallow to provide a natural habit for wildlife. All their land is located around the farmstead.

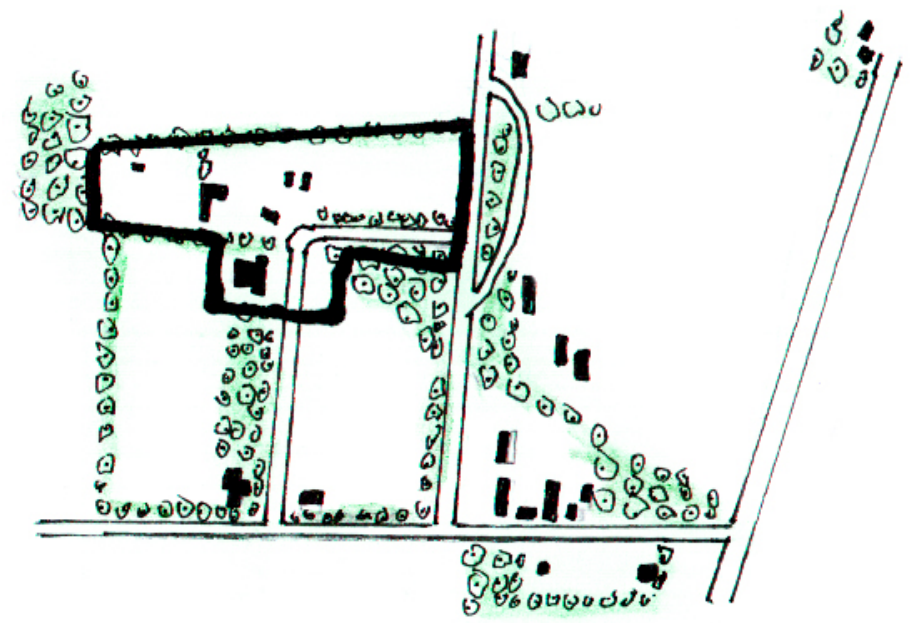

Figure 6: farm 2

\section{History}

The area that is now occupied by the farm has been cultivated at least since the 19th century. In the 1940 s, a commercial beef and fruit farm started business, but abandoned the place in the 1980s. During the time of their operation, they built a farmhouse, a house for processing, and a barn. The land has subsequently been leased to surrounding farmers and used predominantly for field crops. That did not change after the parents of the current farm owners purchased the land in order to relocate to it in the 1990s.

In 2002, the older brother of the current farm owners leased the land from his parents and started the operation with the help of a number of friends and his younger brother. The latter took over the operation in 2008, when the older brother moved out of state. A few years later, the farm joined the WWOOF network and invited volunteers to the farm.

Since the older brother's return to the farm in 2012, they operate together. 


\section{Built environment and spatial organization}

The current farm buildings trace back to the previous beef and fruit farm. The original, grand, Victorian-style farmhouse is currently used as the home for the parents. The brothers used to live here too as teenagers, but decided to move out later. They now live in their own homes, not very far from the farm. They do, however, need to drive in order to get to the farm.

The farmhouse is separated from the rest of the farm by a small streamlet with hedges on each side. It is, however, connected to the farm by a ford and a bridge, as well as a driveway.

On the other side of the streamlet, the driveway ends in a small parking lot. Next to it stands a smaller, two-story house, which used to be the processing building. It is now the bunkhouse for the wwoofers and the interns.

Two polytunnels are situated about $50 \mathrm{ft}(15 \mathrm{~m})$ across from this building to the north. They are used for pre-seeding. Another $50 \mathrm{ft}(15 \mathrm{~m})$ east of the bunkhouse stands a great barn that used to house the cattle, chickens, fodder and machinery. Now, after animal husbandry has been abandoned, it is mainly used as a storage facility.

Two herb beds have been set up right next to the barn. They are cultivated by one of the brother's wife. However, since she very recently gave birth to a child, the wwoofers help her out weeding these beds.

The space between the barn, the polytunnels and the bunkhouse is to a great extend left open in order to allow moving from one building to the other, including driving trucks, tractors and other machinery. Some parts, however, are planted with flower and small vegetable beds, as well as fruit trees. Another part of this area is used to store straw that is used for mulching.

The buildings are surrounded by the majority of the farm's vegetables fields, which in turn are enclosed by a row of trees, predominantly Black Walnut (Juglans nigra). The entire farmstead is about 8 acres ( $3 \mathrm{ha}$ ) in size. Right next to the barn is another row of walnuts that separates the farmstead into an eastern part, which contains all the buildings, and a western part, which is mainly used for production. The latter also features a small cabin that was built by the brothers. It used to be the home of one of the brothers and is now mostly used for herbalism workshops.

Both the cabin and the bunkhouse have two small outhouses close by.

Since the launch of the current farm, a great number of trees have been planted throughout the farmstead. That includes fruit trees like Apple (Malus domestica), Peach (Prunus persica), Apricot (Prunus armeniaca), Serviceberry (Amelanchier spec.) and Cherry (Prunus avium), as well as other trees such as Sumac (Rhus typhina), Catalpa (Catalpa bignonioides) and even Redwoods.

\section{Social organization and labor}

This operation is a family farm, run by two brothers who did not grow up on a farm. Unlike their parents, who still live on the property, the brothers moved away from the farm. The younger brother's partner, who runs a flower farm herself, helps with marketing the products. The older brother's wife is a trained herbalist who grows and processes herbs on the farm, which are also for sale. She had just given birth to their first child.

Throughout the growing season, the farmers invite wwoofers and interns to the farm. They receive board and food in return for working roughly 40 hours a week. This should not be confused, however, with a traditional wage-labor relationship, where wage is paid in kind.

The wwoofers are invited to become part of the farm family, which includes both demands and provisioning. In the words of one wwoofer: 


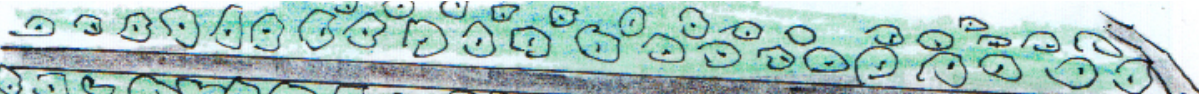

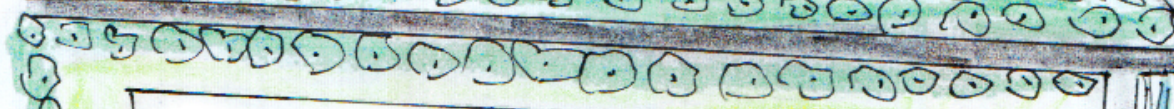

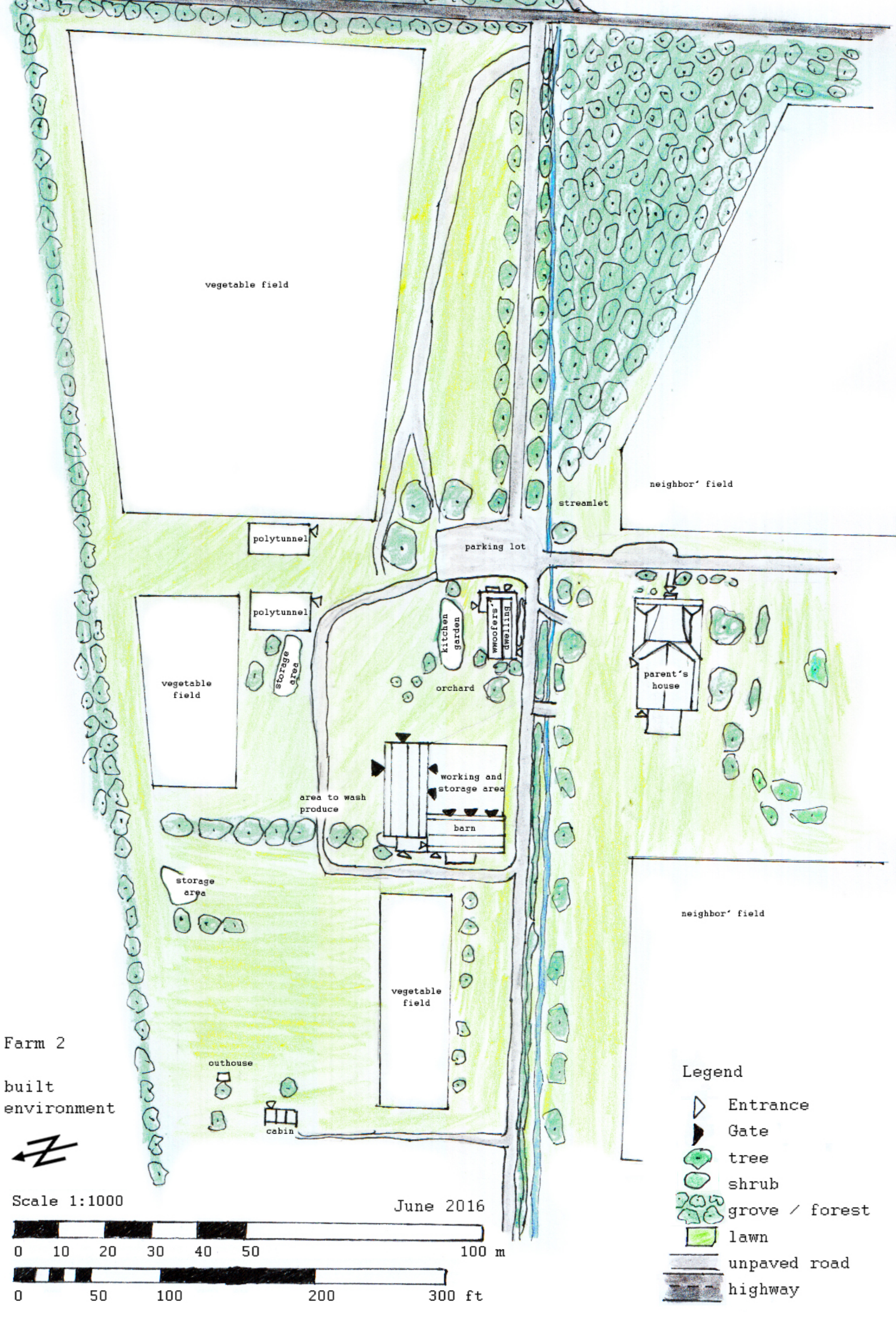


"I get treated as family. I get the implicit support of the family, which essentially means that they are willing to feed me, provide me with a place to live and then take care for any other of my basic needs that I have. As well as catering to my less basic needs, like emotional needs that I feel paid workers might not receive in the same way." (wwoofer at farm 2, personal interview, 18 June 2015)

However, the same wwoofer also expressed a feeling of ambiguity. While being treated as family, he also sometimes feels like a farmhand who is subject to the farmer's decisions. This can create some tension among the people on the farm when roles and, as a result, rights are not clearly defined.

At the time of the visit at the farm, there were six wwoofers. Two of them were friends from New York City in their early twenties, who have worked on this farm before and stayed here several months. Two other are friends from out of state, who had also worked on this farm before and who come here in their summer break from college. The remaining two wwoofers were a young couple who took a semester off from a nearby college.

The cousin of the two brothers also helps out on the farm. His main passion and responsibilities are the trees on the farm, but he also mows the lawn, tends his own experimental bed and helps out selling at the market.

The parents of the brothers, who own the farmland and lease to their children, live in the original farmhouse, which is now separated from the actual farmstead. Both have regular day jobs in town. They cooperate with the farm by letting the wwoofers use their bathroom and shower (the bunkhouse does not have a bathroom), their internet, as well as their living room. The mother also uses the farm's polytunnels.

Long-term decisions regarding the farm are made by the brothers, and then discussed with their family. Day-to-day decisions about what needs to be done and by whom are made by the younger brother.

The farm does not yet have a successor in sight. The current operators are still young and do not plan to address this issue any time soon.

Along with the human population of the farm, there are a dog and two cats.

Most of the farm family and the volunteers expressed a strong interested in spirituality and gratitude for their community and provision with food from their farm.

\section{Economical organization}

The farm operates on a regular basis. The main pillar of the farm is produce. They grow a vast range of more than 25 different vegetables and lettuces. While most of the vegetables are produced on a very small scale, garlic is grown on a bigger field of about 1 acre $(0.4 \mathrm{ha})$ off site, but connected to the farmstead. In addition, they also produce a number of different fruits and berries. They also grow a number of herbs.

The farmers were considering including livestock into their operation in the future. At this point, however, they appreciate the freedom to use the winter months for traveling instead of having to tend the livestock.

The farm processes some of their products (garlic, green tomatoes and hot peppers) to add value and preserve it for the winter. The farm sells their products exclusively through direct marketing. They have a small CSA with about 20 members and they sell to some restaurants in the area. However, most of the farm's monetary income is derived through sales at various farmers' markets throughout the Ithaca region.

At the market, they not only sell their products, but also trade them for other goods with the other vendors. That way, they are supplied with products they cannot or do not want to produce themselves, such as eggs, cider, bread or mushrooms. Thus, at least throughout the market season, the 
farm is able to provide most of their diet themselves or through trade. Only a few products are purchased elsewhere. However, in the winter time, the dependence on food from supermarkets increases.

The farm is certified naturally grown, but does not receive any government subsidies. They considered becoming certified organic, but refrained from it, because it takes a lot of paperwork and they do not think it is required by their customers.

While most seeds are bought externally, beans, corn, and garlic are propagated on the farm.

The farm did not take out a loan to invest into their business. The farm makes about $\$ 40,000-$ $\$ 50,000$ in annual sales.

\section{Cooperation with other farmers and the community}

The farm has set up a CSA with about 20 customers, who either come to the farm to pick up their share or who can pick up produce at the market stands.

The farm is a member of certified naturally grown and thus part of a national network of farmers that aims to guarantee and improve the sustainability and ethical farming practices of their members.

They cooperate with some of the surrounding farmers by sharing knowledge and their disk harrow and bulk ordering seeds.

As sellers at the Ithaca Farmers' Market, they are part owners of the market. They do not only use the market for business, but also as an opportunity to converse with the other farmers and to trade products.

They get support from Cornell Cooperative Extension, an outreach program by Cornell University.

\section{Equipment}

The farms own two tractors, a disc harrow, a tiller, a brush hog and a plow. They try to repair as much they can. If they cannot, they call a trusted welder. They buy both used and new. 


\section{Farm 3: Large-scale, organic grain operation (1200 acres)}

\section{Summary}

This farm is a commercial, organic grain farm on 1200 acres (486 ha). Besides growing a number of different crops themselves, they buy, process and market grains from other producers. The farm was started in 1993 by the current operator.

\section{Location and size}

The farmstead and most of the land sits in a very hilly and forested part of the area under investigation. Recently, more land has been leased further north, where the land is less hilly and generally better suited for agriculture.

The farmstead lies on a county road with several farms, about a mile outside of one of the smaller towns in the area.

With 1200 acres (486 ha) in farm, the farm is the biggest organic grain producer in the area. The farm owns only 40 acres ( $16 \mathrm{ha}$ ), which means that $99.7 \%$ of the farmland is leased. According to the operator, they have gained a reputation of being good stewards of the land so a lot of local landowners have chosen to rent them land for very favorable conditions or for even no rent at all.

The farmland is made up by a lot of very small patches, often several miles apart from each other. This causes a number of logistic problems concerning efficient uses of equipment and moving machines and workers between the fields. Some of the fields are completely inaccessible for bigger machines.

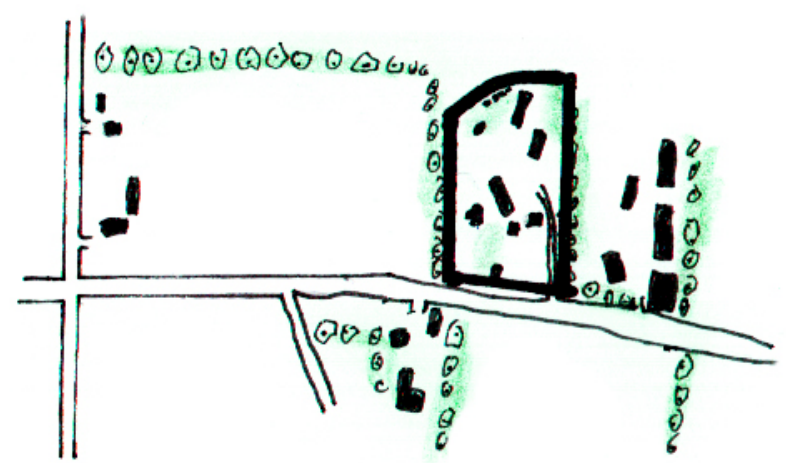

Figure 7: farm 3

\section{History}

The current operator bought the farm in 1991. He did not grow up on a farm himself, but become interested in agriculture while visiting his uncle's small hill farm and consequently working on several farms.

Originally, the farm used to be a small subsistence farm, but had not been in operation for a long time. The buildings, the barn dating back to 1860 , were devastated and overgrown with trees. It was sold when the last inhabitant, an old woman, had moved to a nursing home.

Until the early 2000 s the farm was operated as a sideline. It started out as a 4-acre vegetable farm, but soon converted to grain production. During the years, the operator had built up his acreage until he reached between 400 and 500 acres (162 and 202 ha), which he deemed large enough to run the farm full-time. This was when he quit his off-farm job. 
After that he kept increasing his acreage to the 1200 acres (486 ha) he farms now.

His wife moved onto the farm around 2007.

\section{Built environment and spatial organization}

The farmstead sits along $500 \mathrm{ft}(150 \mathrm{~m})$ of the highway and is about $630 \mathrm{ft}(192 \mathrm{~m})$ deep. It is separated from the street by a hedgerow that has grown out to a row of trees. Two driveways lead onto the farm. It is separated into two sections; the homestead facing the highway and a set of agricultural buildings and facilities geared toward the production in the back.

The section facing the highway is dominated by a large lawn, a row of relatively young fruit trees, an idle vegetable field and the farmhouse, which was taken over from the original farm. It is a two-story, wooden building, tucked between a large apple tree and a few perennial, ornamental flowers on the one side and a row of large, mixed trees on the other. It is likely that this row used to be the boundary of the original farmstead. Now, however, a small path leads underneath the trees to a paddock and the horse stable.

Apart from an electric wire fence, there is no boundary mark to the highway. There is, however, another row of trees that separates the paddock from the neighbor's land.

The two sections of the farm are separated by a row of trees to the west and a small, two-story, mixed storage and residential house (home to the hired man), and the old barn to the north. The barn was built around 1860 and is now used to store straw and small equipment. Occasionally, when the farm hosts a party, this barn is used as a venue for live music.

"I sort of feel those old barns are the heart and soul of a farm. So we spent a lot of time and money just getting it back together. It's a useful building. Not the most useful, but I just like having it there because it is sort of the cornerstone of the farm." (farmer at farm 3, personal interview, 30 June 2015)

Behind these two buildings is a large driveway that is surrounded by the barn and the hired man's house, two large machinery and storage halls, a workshop and a total of 10 grain-storage silos. The farmstead is separated from the field in the back and the neighbor by more rows of trees.

\section{Social organization and labor}

The farm family consists of the operator and his wife, who refers to herself as a farmer's wife. They are both in their fifties and do not have any children.

The farmer worksfull-time on the farm and is responsible for all business decisions. He is involved in all activities regarding the agricultural production, maintenance of machinery and marketing. His wife, besides working off-farm part-time, secures the logistics of the operation by running errands and transporting people and equipment from field to field. She carries out the productive household work and tends the livestock.

The so-called hired man, a wage laborer who works for the farm full-time, also lives on the farm. Before he came to the farm five years ago, he worked on dairy farms and received a bachelor's degree in Agricultural Sciences at Cornell. While he works many hours overtime in the summer, he gets time off in the winter. His main activities are related to the agricultural production and increasingly in taken care of the equipment. Also, he keeps bees. He is about to move a few miles off the farm, but will continue working for them.

There is another wage worker who comes in three days a week in the summer. The rest of his time, another three days in the summer and full-time in the winter, he works at the farmer's flour mill. This way, he can be employed full-time throughout the year, even though there is less work to do on the farm in the winter.

The operator stated that in the summer there is enough work on the farm for two full-time hired workers. 


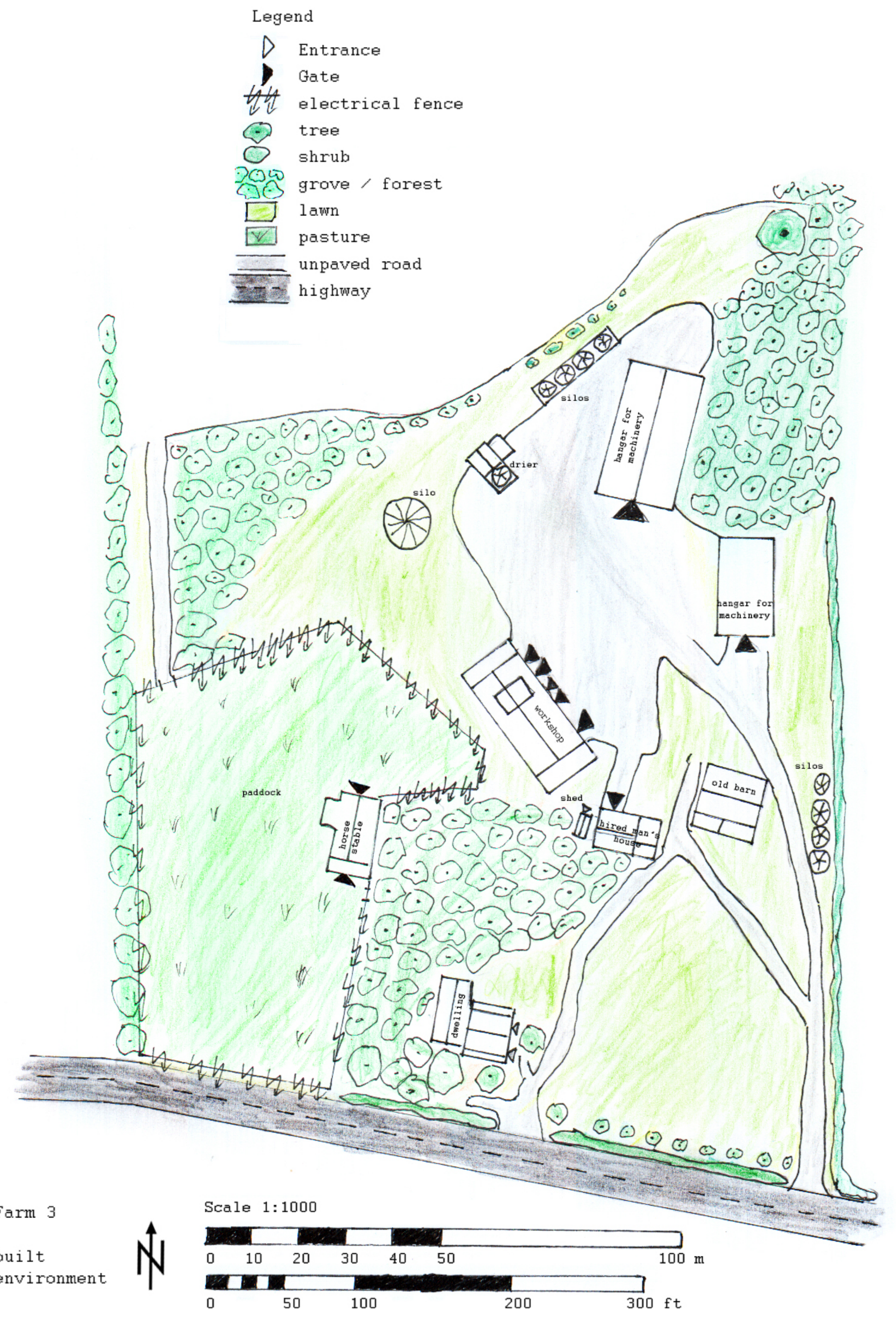


On demand, the farm receives additional help by a sheep dairy farmer who is a friend of the family. Whenever there is an acute shortage of labor, especially when it is time to harvest and rain is approaching, the operator calls him and he comes over to help. That happens about five days a year. The labor is reimbursed in hay for the friend's sheep.

The farm sometimes contracts a conventional crop farmer and friend to harvest some of their crops with his combine, which is considerably bigger than any combine the farm owns itself.

Currently, there is an intern who comes to the farm once a week. She helps at the farm and at the same time learns how to run a farm, which she aspires as a career.

The farm does not yet have a successor for the operator. They do not have any children, nor do the farmer's nieces and nephews have any interest in taking over the farm. The farmer considers selling most of the farm for his retirement, but wishes to find a young farmer who is willing to take over. $\mathrm{He}$ wishes to transfer the operation by the age of 60 , but has not yet actively looked out for a successor. Either way, he wishes to farm as long he physically can, but on a much smaller scale.

\section{Economical organization}

The operation is a large, certified organic grain farm. They commercially grow a diverse selection of field crops: corn, rye, wheat, buckwheat, oats, hay, alfalfa and clover. Economically, the farm considers the first three the most important crops for their business.

As the farmer stated, the operation is "tied and locked into the whole capitalist financial system" (farmer at farm 3, personal interview, 30 June 2015). The vast majority of the yield is sold for money to generate income to buy inputs for the production (mostly fuel, manure fertilizer and machines), as well as means of subsistence. Despite making roughly $\$ 500,000$ in annual sales, the farm usually carries a debt load of around $\$ 200,000$, mainly to finance equipment and farm buildings.

While the farm sometimes buys seeds for testing, they save their own seeds. By seed-saving and keeping cash reserves, they plan to always be able to plant new crops without having to take out additional loans.

Despite growing bulk crops, the farm sells most of its products directly to a diverse selection of customers. They sell seeds and hay to other farmers and grain to distilleries, breweries, malt houses, feed mills, a flour mill and a wheatgrass producer.

In order to create a value-added commodity, they co-founded an organic flour mill in 2008 , which processes a great part of the farm's crop into flour and sells it directly to a great number of retailers. Despite being a separate enterprise, the flour mill is directly linked to the business of the farm. It also mills grain from other farmers.

The farm also purchased equipment to clean and sort grains in order to sell them as seed, which is another value-adding process.

The marketing of the farm is not limited to their own crops. The farm also buys, processes and sells grain from other organic producers. According to the operator, fair payment and transparency are key values of his business relations.

"The guys I'm working with selling their crops, I pay them really well for their stuff. Way more than they gonna get anywhere else. So they're really excited to grow stuff for me. I just make sure that my margin that I take on is not so much that everybody gets a chunk of the pie. If I'm gonna sell it for $x$ amount I want the amount I make to be the same as what the guy I'm buying it from is. So I'm not making all the money that the middleman normally does. That income is more balanced between what the grower has and what I have."

(farmer at farm 3, personal interview, 30 June 2015) 
"I always tell them 'OK, I'm gonna make three cents a pound to clean it and I'm gonna add two cents a pound to that for my time and marketing and all that. Does that sound fair to you? So there isn't any mystery in who is making what."

(farmer at farm 3, personal interview, 30 June 2015)

While generating high profits every year, this business model is very labor intense in terms of administrative and marketing work, which is done by the operator himself. He explains:

"When I think back when we were just growing crops and bulk marketing them we had so much more time. I have like zero extra time now. 'Cause when I'm not farming I'm on the phone or I'm up there working with customers and doing all these other things. There's a cost to that. The cost is my free time."

(farmer at farm 3, personal interview, 30 June 2015)

Another income stream is custom work. Occasionally the farmer harvests other farmer's crops on demand with his combine.

As a backup for less productive years, the woman farmer works off-farm part-time. At the time of our interview, they had never depended on that income.

The farm is strongly engaged in informal exchange relations with other farmers in the area. For instance, the farm trades cover crop seeds for a vegetable CSA share and wheat cleanings for a slaughtered pig. In some cases, the farm gets to lease land for free in exchange for cover crop seeds or straw bales. They also trade services and labor with other farms.

Part of why the farm was able to increase in size up to 1200 acres (486 ha) was due to the fact that they were able to rent a lot of land cheaply or for free because of their reputation as reliable and good stewards of the land.

Beyond the commercial production the farm is also to some degree engaged in subsistence production. When the farmer's wife moved onto the farm, they started to keep a few chicken for eggs. They also harvest fruit from a number of apple, cherry and pear trees they have either planted themselves or that remained from the original farm. They also cultivate currents, grapes, raspberries, strawberries and a few herbs for their own consumption. Moreover, they cut their own firewood and keep bees for honey.

However, they deliberately decided not to keep a garden and instead trade vegetables and meat with other farmers and purchase commodities from the money earned by commodities they have sold. As the farmer puts it:

"... with the amount of trading that we do with other farmers, time is better spent for me focusing trying to make the farm work and have the farm produce income to buy those things and other products that I can trade for other food products that we need."

(farmer at farm 3, personal interview, 30 June 2015)

The wife also keeps two horses on the farm for endurance riding.

The farm receives government subsidies through the USDA ARC and PLC programs. They also take part in conservation and stewardship programs through the NRCS, like the Environmental Quality Incentives Program.

\section{Cooperation with other farmers and the community}

The farm strongly engages in the local farming community. In fact, the operator's commitment to support the local agricultural economy has given him the reputation of being a mentor for younger farmers. As he also publicly speaks on panels on farming, he is widely known throughout the community. 
As described, the farm engages heavily in the informal trading economy among farmers. They trade products, labor and services. Throughout the interview, the farmer pointed out that the other farmers are not merely business partners but friends:

"You could do a straight up cash thing but a lot of times... these people are friends of mine, first of all." (farmer at farm 3, personal interview, 30 June 2015)

They share a mowing machine with another farm and plan to purchase a $\$ 100,000$ baler with another one.

Besides adding value to their own crops and yielding higher prices, the farm co-founded their flour mill to generate better prices for local farmers and thus strengthen the local economy.

He and a friend also co-founded a bakery to provide the Ithaca community with local, organic bread, a sought-after product that was previously unavailable. He does not make any monetary profit through the bakery.

The farmer offers informal mentorship to beginning farmers. They call him for questions or visit the farms as interns. He shares his knowledge at meetings of various agricultural organizations, universities (Cornell and Pennsylvania State University), as well as at more socially oriented community events. Similarly, he calls other, more experienced farmers whenever he needs help or mentorship.

They are members of New York Certified Organic (NYCO) and Northeast Organic Farming Association NOFA. An important support network for the farm is Organic Grain Research and Information Network (OGRIN), which is run by a friend of the operator. They offer information on seeds and crop varieties and connects the operator to researcher for more specific information.

\section{Equipment}

The farm relies on the use of extensive machinery. They own two combines, eleven tractors, five trucks, planters, mowers, cultivators, tine weeders, harrows, a utility trailer, a seed cleaner, a skidsteer loader, three planting machines, tillage machines, hay-making equipment, fours plows, field cultivators, rolling harrows and rollers. The farmer estimates the value of their equipment at over $\$ 1,000,000$.

Additionally, they have six silos for storing grain and processing equipment such as a seed dryer, cleaning and sorting equipment.

The farm keeps several tractors for different jobs. For example, smaller tractors are used to access fields that are inaccessible for bigger ones. If suitable for the land, the latter are more powerful and get more work done in less time. Some machines can only be powered by the bigger tractors as the smaller ones are often too weak for certain tasks. In addition, having several tractors allows the farm to park them at different locations so they have to drive less from field to field. Also, there is redundancy if a machine breaks.

The farm jointly owns a $15 \mathrm{ft}(4.6 \mathrm{~m})$ wide mowing machine with another farmer.

Being a trained mechanic, the farmer and his hired man are able to do about $90 \%$ of the repair and maintenance work. However, in recent years, the farm has increasingly purchased newer equipment, which is more difficult to repair. These machines require certain computer soft- and hardware to be repaired. For those the farm calls in specialists from the manufacturer. For the farmer, this disadvantage is balanced by the newer tractors' greater comfort levels. They come with a cab with air conditioning and better suspension, which is easier on the body.

While not owning the machine itself, the farm utilizes a $\$ 200,000$ combine for harvesting by contracting a neighboring commercial farmer for a few days during harvest season. 


\section{Farm 4: Organic vegetable farm (47 acres)}

\section{Summary}

This farm is a commercial, organic vegetable farm on 47 acres (19 ha). The operator was raised on a farm, but branched out to start his own.

\section{Location and size}

The farm is scattered around different locations on the outskirts of two small villages in Tompkins County. It's an area of rolling hills, dominated by dairy farms.

They own three sites of farmland that total 45 acres (18 ha). A small field and a paddock sit right next to the farmstead. The second and larger field is about 0.3 miles $(0.5 \mathrm{~km})$ away from the farmstead. The third site is right next to the operator's father's farm, about 4.5 miles $(7 \mathrm{~km})$ away. All fields are directly connected to a highway instead of being separated by hedgerows.

\section{Built environment and spatial organization}

There was no opportunity to visit the farmstead during the field visit.

\section{History}

The operator, who grow up on a large dairy family farm in the area, started his own farm in $1997 . \mathrm{He}$ did not enjoy working with animals and did not get along well with his cousins who were working at his parent's farm at that time.

When he started his own farm on his father's land, he did not have any employees or additional family labor and grew three to four bulk commodities and sold them wholesale. He left the farm for a few years to take on a job out of state.

When he returned to the farm in 2004 , he started with a different approach. He focused on diversity and direct marketing and started employing additional workers.

\section{Social organization and labor}

The farm was started by the male operator, who is a farmer in the third generation. He grew up on a nearby dairy farm, but decided to start his own farm while his brothers are in the process of taking over his father's business.

The farm has hired farmworkers. They are all in their twenties or younger. Most of them work fulltime, Monday to Friday from 7 a.m. to 4 p.m. with an one-hour lunch break at noon. One of the workers who is a student at a nearby college works half-time during the school year, while another one works seven days a week.

All decisions regarding the farm activities both long-term and from day to day are made by the operator alone.

His wife does not work in the field and has a full-time job off-farm. She is responsible for the preparation and processing of the farm products and takes care of their two sons.

The operator does not yet have a successor for the farm. He is doubtful if he wants his children to become farmers because it is hard work and poorly paid. Hence, he is considering selling his farm back to his father's farm. 


\section{Economical organization}

The operation is a commercial, certified organic vegetable farm. They sell directly at the Ithaca Farmers' Market as well through a summer CSA with about 250 shares. In June, they offer a strawberry Upick. They also sell a small part of their harvest wholesale.

In the winter, the farm sells storage products and preserves, which are processed by another farm. They are planning on starting a winter CSA as well.

The operator works full-time on the farm, while his wife works off-farm full-time to supplement income.

Besides being paid, the employees can take as much food as they want whenever something is left after a market day or when CSA-boxes are not picked up. Excess food is also donated to two food banks in the area.

The farmers produces most of their vegetables themselves. Sometimes in the winter, they buy frozen vegetables at the supermarket. They get eggs from their tennant, as well as lamb meat. They keep one pig that is fed kitchen scraps and gets slaughtered at the end of the year for meat for the family.

The farmer took out a loan for a tractor. While they are at a point where they could use more equipment, they are trying to grow slowly so they do not have to take out any more loans.

The wife keeps horses for riding.

\section{Cooperation with other farmers and the community}

The farmer sometimes borrows equipment from his father's farm. But since he got his own tractor, this happens less frequently.

"I'm too busy to use someone else's tractor. When I need to get something done I need to get it done. I can't wait." (farmer at farm 4, personal interview, 1 July 2015)

The farm does not trade much with other farmers. During the market, they sometimes trade produce for hot coffee or a meal with some of the other vendors. 


\section{Farm 5: Start-up vegetable farm (5 acres)}

\section{Summary}

This farm is a small, diverse, certified natural grown vegetable producer. Operated by a young couple, the 4.88-acre (2 ha) farm started in 2011, but has changed its location from its original founding. While still being backed by off-farm income, the farm is growing in an effort to operate on a regular basis.

\section{Location and size}

The farm is situated in an area of gently rolling hills about $1500 \mathrm{ft}(500 \mathrm{~m})$ off a minor backcountry road. It is tucked between a pond and another farm, which owns the land currently operated by the farm under investigation.

The farm leases 4.88 acres ( 2 ha) of officially recognized farmland for free. The farm recently purchased 19.08 acres $(7.7 \mathrm{ha})$ about 8 miles $(13 \mathrm{~km})$ further east but has not started to cultivate it.

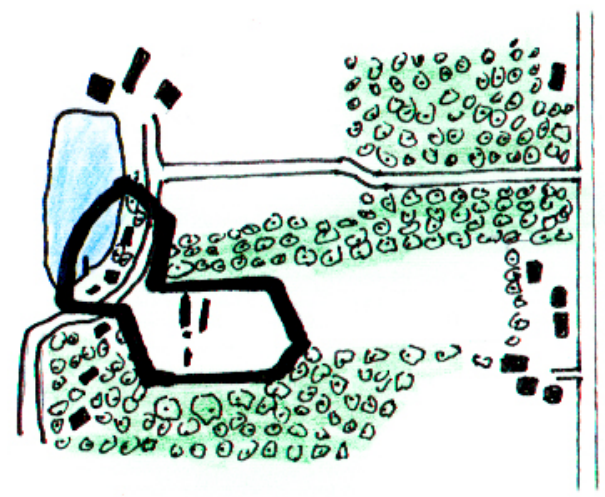

Figure 8: farm 5

\section{History}

The farm started in 2011 as a very small CSA with eight shares (all of the shareholders were friends of the farmers) at a different location, about 20 miles $(32 \mathrm{~km})$ west. They moved to that land to tend someone else's homestead in exchange for free rent. When the owners of the homestead returned in 2011, the farmers moved to the current site. Friends of friends of theirs had just purchased that land and were looking for someone to farm it. From then, the farm has scaled up their production every year. During that time, they saved money so they were able to buy their first land, 19.08 acres $(7.7$ ha) about 8 miles $(13 \mathrm{~km})$ further east. They are currently building a new house and plan to start growing vegetables at the new location next year, along with the current location.

They used to have chickens for meat in the first two years of operation. They stopped raising chicken when they realized that this business wasn't profitable enough on their scale. They are considering keeping livestock for themselves at their new farm.

None of the operators grew up on a farm, but one had some experience working on a farm as a teenager. They met each other while studying at Ithaca College. Since there were no jobs in the field they were studying, they decided to wwoof for some time. It was during that time that they decided that they never wanted to pay rent again and would farm some land in exchange for free rent. From there, they scaled up until they called themselves farmers. 


\section{Built environment and spatial organization}

The two farmers live in a trailer near a pond, separated from the driveway and the rest of the farm by a row of trees. On the other side of the trees, between the driveway and pond is a slightly bigger, one-story, wooden cabin that is currently rented out. Behind the cabin is a gazebo, a picnic area and a small dock leading onto the pond.

Opposite of the cabin is the productive part of the farm: one large fenced-in field accessible through a gate from the driveway. In addition to the rows for planting, there are four polytunnels and a wooden shed without walls to store tools and get some shade in the summer.

\section{Social organization and labor}

The farm is run by a young couple. There is not a single principal operator, but all decisions are made jointly. Both of them work part-time off the farm.

They have one paid employee, who works at the farm ten hours a week, as well as on two other farms. She was the farm's first intern.

The farm has set up a workshare scheme for the growing season, May through November. Currently 12 workers come here for three hours of work in exchange of a CSA share.

The cousin of one of the operators was working on the farm during the summer of the interview in return for board and lodging. The farmers were considering inviting wwoofers once they moved to their new location. The sister of one of the farmers and her boyfriend live on the farm as well. While they sometimes volunteer to help out, they are not affiliated with the farm operation.

The farmers do not have children and do not know, who, if anyone, will take over the operation. In the words of one of the operators:

"It is not that important to me. Maybe I feel differently in 30 years. I would think, if we have kids and they don't wanna take over the farm, then they shouldn't. You should only farm if you really want to. (farmer at farm 5, personal interview, 10 July 2015)

\section{Economical organization}

The farm is a commercial, diverse vegetable producer. The operators are aspiring to farm full-time, but both currently work off-farm part-time to supplement income.

About $65 \%$ of their produce is sold through a CSA with 75 shares and the remaining $35 \%$ of their sales is derived from wholesale. They consider that a good ratio.

They are certified naturally grown. Even though they identify with the principles of organic farming, they refuse to get Certified Organic because of the associated paperwork and costs. They feel that selling direct to customers that know the farm does not require any certifications. The farmers are considering selling in New York City, in which case they might have to become certified organic because customers there would be less familiar with the farm.

The farm once received a NRCS high tunnel grant, but does not currently receive any other subsidies. They do not know of any subsidies that might be applicable for them.

They are not members of any professional association other than certified naturally grown.

Self-sufficiency is very important to the farmers and the reason that brought them into farming. Throughout the year, they rely on their own vegetables for self-consumption. Exclusively for homeconsumption, they can and pickle some of their produce for the winter and make their own salsas. They decided that they do not have to keep livestock for meat because they are friends with many 


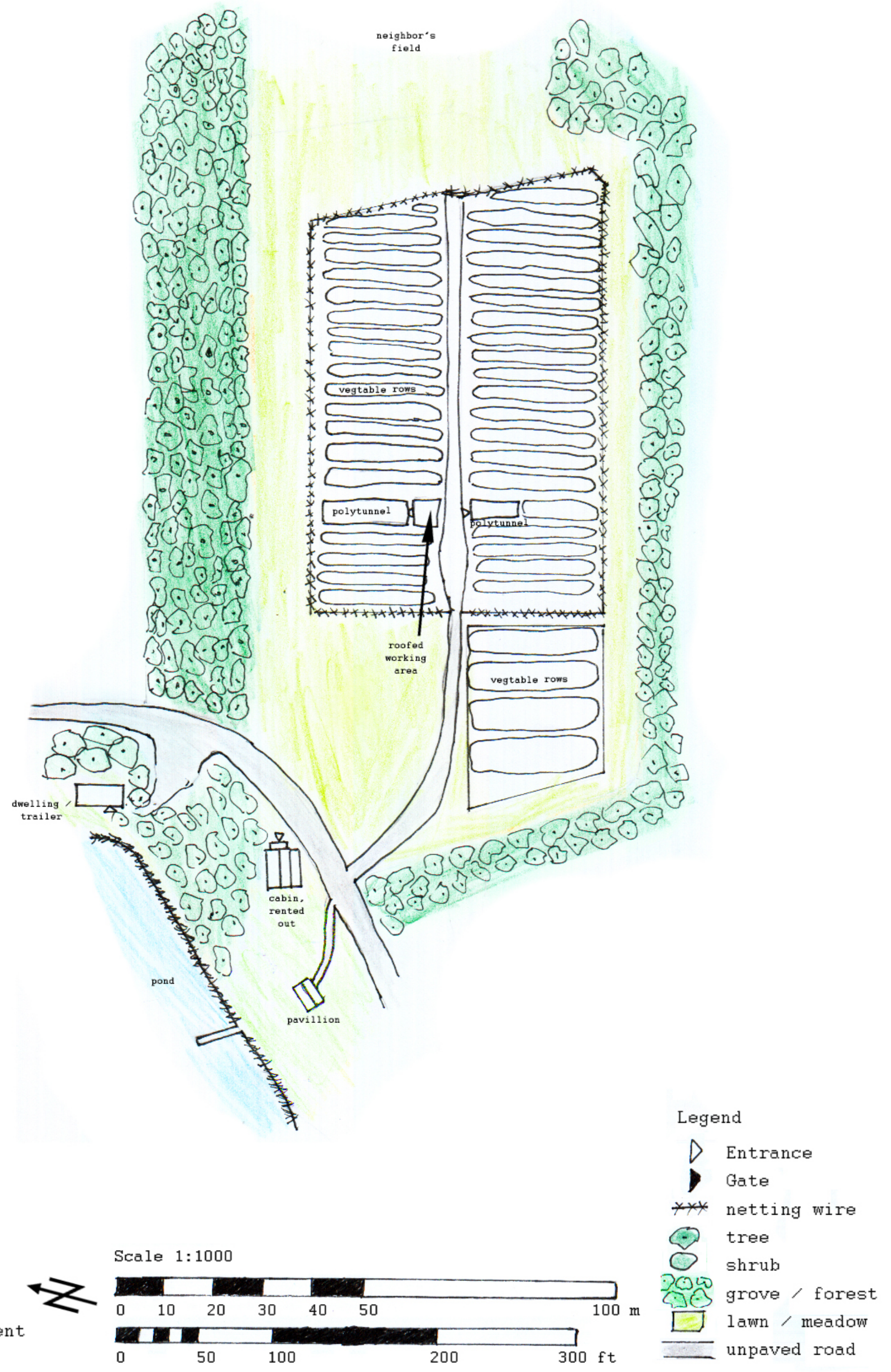


livestock farmers who trade meat for produce with them. Through this arrangement, about $50 \%$ to $75 \%$ of the meat they consume is traded with farmers they know.

The farmers never took out any loans for farming. They did take out student loans but these are mostly paid off. Their strategy to remain debt-free was to trade work for rent and to grow gradually by reinvesting profits.

The farmers decided not to save any seeds as they used to in the past. They figured it was too much work and it would suit them better to buy seeds from professional seed companies.

\section{Cooperation with other farmers and the community}

They share knowledge with the surrounding farm community but do not cooperate with them in any other way. They also participate in various online forums for farmers to exchange knowledge.

They sometimes work with and get help through Cornell Cooperative Extension and Groundswell.

They do not trade any equipment with other farmers.

\section{Equipment}

The farm owns two tractors, a brush hog, a walk-behind tractor, two wheel hoes, a flame weeder and various hand tools. 


\section{Farm 6: Organic dairy farm (2300 acres)}

\section{Summary}

With 700 cattle, this family farm is one of the Northeast's biggest organic dairy operations. The specialized farm grows feed and keeps their cows on 2300 acres (931 ha) with two different farmsteads. Besides selling the milk to a major dairy in Upstate New York, they run a small farm store where raw milk, fruits and products from other surrounding farms is sold. The farm was started in 1946 and is currently in the process of being transferred to the third generation.

\section{Location and size}

The farm is situated on two different locations, 12 miles $(19 \mathrm{~km})$ and 18 miles $(29 \mathrm{~km})$ east of Ithaca, respectively, and 5 miles $(8 \mathrm{~km})$ apart from each other. The surrounding area is characterized by rolling hills and dairy farms.

The operation runs on a total of 2300 acres (931 ha), of which 1300 acres (526 ha) are owned by the farm and 1000 ( $405 \mathrm{ha})$ are leased. They have 550 acres (223 ha) in pasture and 1680 acres (680 ha) tilled for crops. The remaining 70 acres ( $28 \mathrm{ha}$ ) are environmentally protected areas for which the farm receives payment for their stewardship.

The site that was visited is situated about a mile outside a village along a county road with their pastures surrounding the farm.

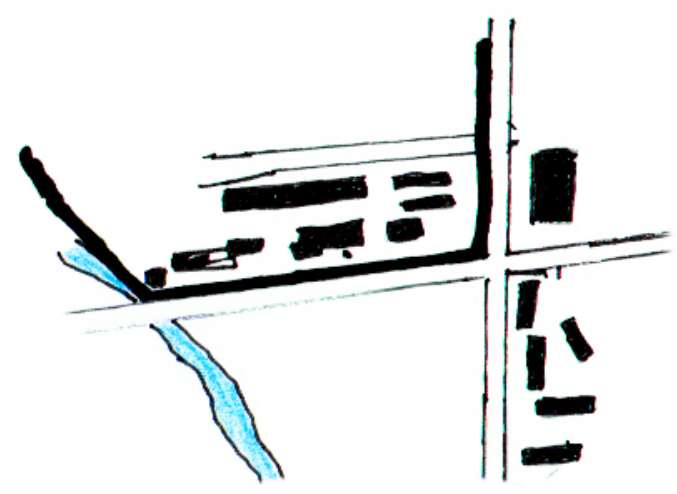

Figure 9: farm 6

\section{History}

The farm started in 1946, when the father of the current operator bought some land and 40 cows with a $\$ 7000$ compensation for his brother's death in World War II. He had become interested in agriculture by working on other farms.

While the farm started out small, it has grown ever since. There was an accelerated time of growth in farm size and intensification when the current operators took over the farm in the 1970s. They were encouraged to intensify following the advice from a friend and professor at Cornell.

When milk prices dropped in the 1990s, the farm struggled to remain profitable. At first the farm tried to meet this pressure with further intensification. Soon, however, they realized that this had put too great a toll on the mental and physical health of both workers and animals. They decided to convert to organic farming in 2000. This quickly turned out to be successful for the farm because the cows were in much better health and the farmers were less stressed to meet the high workload and organizational requirements of intense, conventional dairy farming. 
In the 2010s the farm moved to the current locations because they ran out of space for further growth on their old one. They are now in the progress of transferring the business to the next generation.

\section{Built environment and spatial organization}

Only one of the two locations was surveyed for this study.

The farm sits right next to a minor county road. The large free-stall barn (framed in metal sheets) is only separated from the road by a simple parking lot and a small patch of lawn. Attached to the barn is a large silo and a storage hall for wood chips that are used for bedding (as are sand and straw). Across a courtyard and next to the road is a one-story, metal sheet building that houses the farm store and a storage facility. It is separated from the road by a row of young peach trees. Behind the building there are two greenhouses with tomatoes.

On the other side of the barn are two older, wooden buildings that are used as a garage for the tractors and other vehicles and machines. There is a wall-less barn in the back of the main barn. The cows are able to move freely between the barns and the pasture, which starts right behind the barns.

A large manure pit has been installed across the area where the cows exit the wall-less barn.

\section{Social organization and labor}

The farm is currently owned and operated by the son of the founder of the farm. His two sons are partners in the operation and will become partner operators soon. While they discuss major decisions together, it is the father who has the last word. One of the sons is in charge for the farm store, including the marketing.

There are currently 16 paid full-time workers (including the operator and his two sons). They do not get extra, unpaid help from family or friends. The farm does not make dry hay so there are not any critical peak workloads before rainfall in the harvest season that would require additional labor.

On occasion, the farm hosts interns that provide extra labor in return of an education insight into large-scale dairy farming.

The two sons have another brother who branched out to start his own organic, vegetable farm (farm 4) on his father's land.

\section{Economical organization}

The farm is a specialized, certified organic dairy operation. They keep about 700 cows, Holsteins exclusively, that they breed and raise themselves. By far, most of the milk is sold to the highestpaying dairy, currently Byrne Dairy, one of New York's major dairies, about 75 miles (120 km) away from the farm. This year, they are selling $12,000,000 \mathrm{lb}(5,443,108 \mathrm{~kg})$ of milk at a price of $\$ 39$ per $100 \mathrm{lb}(45 \mathrm{~kg})$, resulting in $\$ 4,700,000$ in total sales. A very small portion of the milk is processed to raw cheese and yogurt. They are also licensed to sell raw milk. Very rarely, the farm sells living cows, mostly those that do not produce milk.

The operation grows corn, soy and hay for their cows, but also relies on additional feed purchased from other farms. They aim to expand their acreage in order to grow more feed themselves. They do not produce their own seeds. The farm roasts their soybeans to make oil and proteins more available to the cows. They also grind their corn. All hay is turned into silage for feed. The farmers appreciate the benefit of not having to get the hay in while still dry, meaning they are less dependent on the weather during harvest season. 


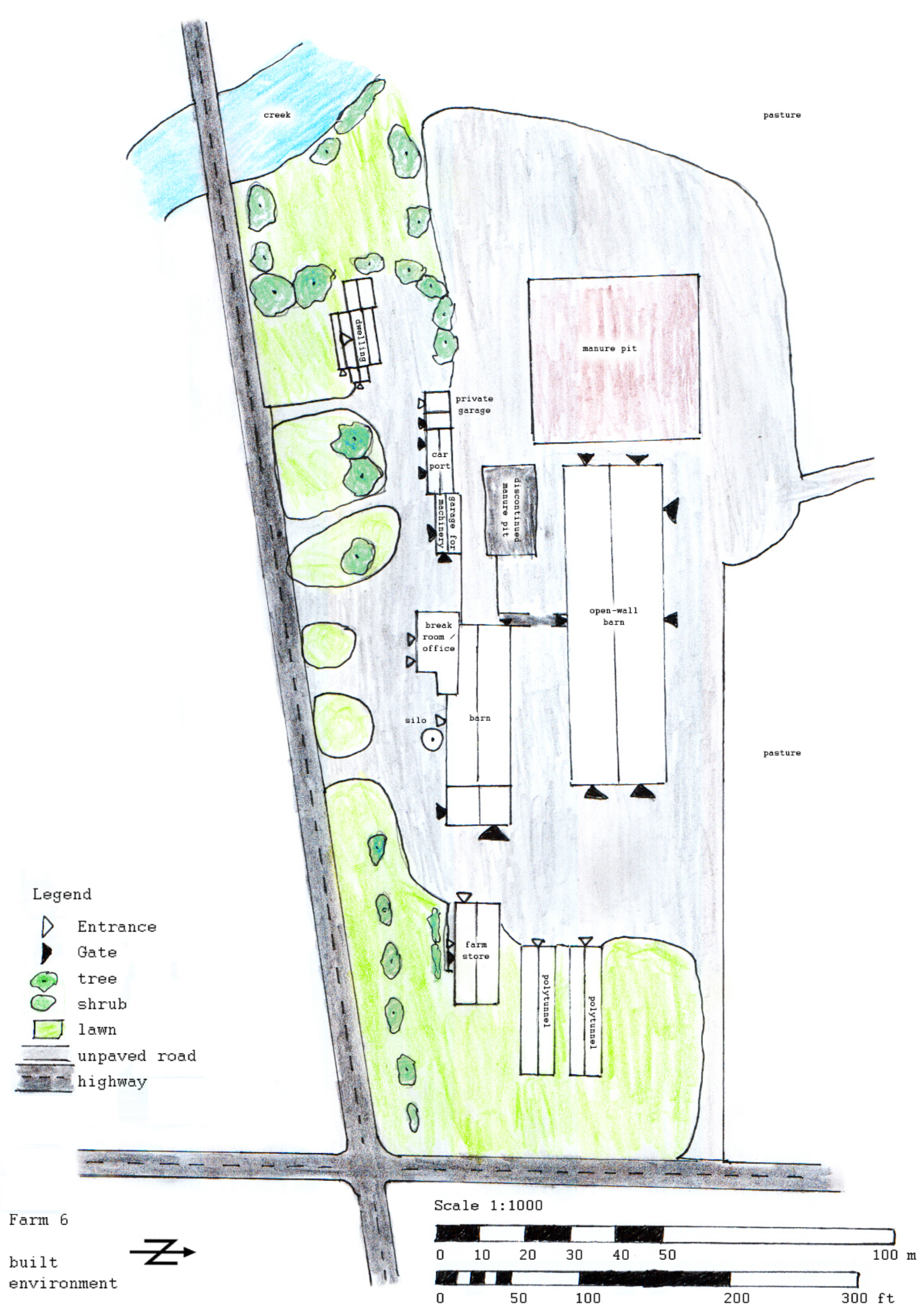


The farm has a few fruit trees for own consumption and direct marketing.

The farm runs a small store at one of their locations. At the farm store, they sell their raw milk, cheese, yogurt, eggs, meat and peaches, in addition to beef and produce from other farmers. In comparison to their main dairy business, the farm store does not make much money, yet it demands a lot of their attention.

The farmers try to source as much food for their own consumption from their own or partnering farms as they can. It is only in the winter that they sometimes need to go grocery shopping.

The farm takes part in as many government programs as they are eligible for, such as the soil and water conservation program and EQUIP. They also have received funding for laneways and storage and some co-funded grants.

\section{Cooperation with other farmers and the community}

The farm purchases additional feed from about 20 organic farms (including farm 3 ). While they do not trade tools and machinery, they sometimes do custom work for other farms. Sometimes, when other farmers are running short on feed in springtime, they sell some haylage if they can.

About a hundred heifers are boarded at another nearby, organic farm.

They attend various social meetings with farmers in the winter and appreciate the advice they get from more experienced organic farmers. Sometimes, when beginning farmers approach them, they give advice, too.

They also take part in meetings and workshops held by Cornell Cooperative Extension, but rely less on their support since becoming part of the organic farming community.

The farm maintains a close relationship with the brother's farm. While being distinct and separate businesses, the farm sells the produce from their brother at the farm store and rely on it for their own consumption.

They are members of Farm Bureau, Northeast Organic Farming Association (NOFA) and the Holstein Association. The son sits on the conservation board of the town.

\section{Equipment}

The farm owns eight tractors, a chopper for hay and corn, a combine, eight plows, three cultivators, two weeders, three manure spreaders, 12 skid steers, a corn planter, a seeder and some drills. Even though they try to buy used machines, they had to take out loans in order to afford the machinery.

The farm employs some skilled mechanics who can repair most machines on farm, but sometimes they call in a contractor from the dealer where the machines were bought. 


\section{Appendix B: Interview guide / questionnaire}

This interview will be about the organization of your farm or homestead and your attitudes towards farming. For the purpose of this study, I look at homesteads as small farms.

By participating in this study, you will contribute to the general understanding of the specific challenges and opportunities of small farmers and help society to learn from them.

As described in the consent form that you have signed, you have the right to skip any question you do not wish to answer and to end the interview at any time. The interview is expected to last about $30-60 \mathrm{~min}$. If you have questions regarding the procedure, please do not hesitate to ask at any time and I will explain it to you.

\begin{tabular}{|l|l|l|l|}
\hline Date & Interviewer: & Johann Strube \\
\hline Name of participant & & & \\
\hline circumstances of interview & & & \\
\hline
\end{tabular}

Note: Not all questions will be applicable to all participants.

\section{Section 1: Self-identification}

1. To get started, I will read you a list of terms. Please tell me, if you find this expression applicable to you. Give reason, why you think the term applies to you or why it does not.
a) farmer
b) homesteader
c) agriculturalist
d) small farmer
e) family farmer
f) peasant
g) subsistence farmer
h) plant or animal breeder
i) businessman/woman
j) anything else?

\section{Section 2: property and farmland}

2. How many acres do you farm?

a) How much of your farmland do you own?

b) How much have you leased?

c) How much land that you own have you leased to someone else?

\section{Section 3: social organization}

3. Besides you, who else lives on this farm?

4. Are you a member of any professional association?

(eg. NOFA NY, Farm Bureau, Vegetable Growers Association)

5. Do you cooperate with any of the surrounding farms or homesteads? How?

(Groundswell)

6. Do you take part in any government programs?

(Soil and Water Conservation District, USDA programs, USDA Farm Service Agency)

7. Do you have any other support resources?

(eg. NYS Department of Agriculture \& Markets, USDA, Cornell Cooperative Extension, CSA, Friends, Family) 
8. How do you come to decisions on what needs to be done on the farm and who is doing what activities?

\section{Section 4: products}

9. Here is a list of products. Please tell me, if you produce any of those and tell me, if you produce them exclusively for sale, primary for sale, primary for home consumption (or barter or to give away), exclusively for home consumption (or barter or to give away), animal feed on farm. (Show list)

(List includes: barley, buckwheat, corn, hay, millet, oats, rye, sorghum, sweet corn, triticale, wheat, apples, apricot, blackberries, blueberries, cherry, currents, gooseberry, grapes, maple, pears, plum, raspberries, strawberries, vine, alfalfa, clover, peas, runner beans, snap/green beans, asparagus, cotton seed, mustard, peanut, rapeseed / canola, soy, sunflower, beets, broccoli, Brussel sprouts, cabbage, cantaloupe, carrots, cauliflower, celery, chard, cucumbers, eggplant, fennel, garlic, kale, leeks, Lettuce, onion, parsnips, peppers, potatoes, pumpkin, radish, spinach, squash, Tomatillo, tomatoes, turnips, watermelon, zucchini, dairy (cow), calves, beef, pork, dairy, wool, lamb, dairy (sheep), eggs (chicken), broiler, eggs (ducks), poultry (ducks), poultry (turkey), other poultry, horses, Christmas Trees, fire wood, floriculture, hemp, herbs, honey, mushrooms, timber, tobacco)

10. If any, which 3 of these products do you identify as most important for your economy? 11. Do you have any other on-farm sources of income, such as a bed and breakfast, workshops, restaurant, etc.?

12. Do you propagate your plants by collecting seeds from your plants?

\section{Section 4: marketing}

13. Where do you sell your products?

14. Do you do any direct marketing?

15. who is in charge of that?

16. Are you affiliated with a CSA?

17. Do you process any of your products in order to realize higher sales prices?

\section{Section 5: home-consumption and self-sufficiency}

18. How important is self-sufficiency for you?

19. To what extent are you able to provide your own family with food that you grow yourself?

20. What are the obstacles that prevent you from full self-sufficiency?

\section{Section 6: Tools and machinery}

21. What machines do you use? (Ask for specific parts of production [crops, pastures, viticulture, forestry, etc.])

22. Do you share any of these machines with other farmers?

23. Did you take out a loan to purchase any of these machines?

24. If any of these machines break, who repairs them?

25. When you buy a new machine, do you buy used or new?

\section{Section 7: Occupation, labor and residents}

26. What are the jobs on the farm that you typically do on the farm?

27. Do you have any occupations off-farm / away from this homestead?

a) How many hours do you work off-farm / away from this homestead?

b) If you were able to live entirely of your land, would you still choose to work somewhere else? Why?

28. Other than you, who else works on this farm / site?

Family labor / Hired labor / volunteers 


\section{Section 8: history / background}

29. When did you start working on this farm?

30. Do you have a family background in farming?

31. Please tell me about the history of this farm. When has it been established?

32. Since how many generations does your family live here? (if applicable)

\section{Section 9: future and perspectives}

33. Is there a successor for the farm already? / Do you plan to take over the operation in the future?

34. How important is the question of farm succession for you?

35. Did you had any major investments in the farm in the past 10 years?

36. Do you plan to make any major investment in the future?

37. How do you see the future of your farm?

38. Now I will read you a list of future or current trends. Please tell me how you anticipate them to affect your operation.

a) climate change

b) industrialization of agriculture

c) increasing debt burden of farmers

e) farms going out of business

\section{Section 10: certifications and subsidies}

39. Do you take part in any certification program (certified organic, certified biodynamic)? why? 40. Which, if any, subsidies do you receive?

41. Would you be applicable for any other subsidies or certifications but did not apply for? Why?

\section{Section 11: Knowledge}

42. Where did you learn the skills needed to operate a farm?

43. Did you receive any sort of formal agricultural education?

44. Do you conduct any research or experiments on your farm?

45. Did you continue learning about farming in the past 10 years? How?

46. Do you spread your knowledge on farming? How?

\section{Section 12: Motivation}

47. Why and when did you decide do become a farmer / homesteader?

48. Why do you continue do become a farmer / homesteader?

49. Do you intend to grow as a farm? Why (not)?

50. From your perspective, what are the specific advantages and disadvantages of small farms compared to bigger farms?

\section{Section 13: Economic organization}

51. how much money does the farm make a year through the sale of agricultural products? (give range: $\$ 0$ - \$1000 - \$2500 - \$5000 - \$10000 - \$20000 - \$25000 - \$40000 - \$50000 - \$100000 $\$ 250000-\$ 500000)$

52. Is your farm officially recognized as farmland? 


\section{Appendix C: Glossary}

Amish: group of Christian communities in North America that live in secluded, homogeneous communities and reject many modern technologies. Their economy is based on agriculture and craft.

Agriculture Risk Coverage (ARC): a federal commodity subsidy program, with payments based on acreage of a commodity and retail prices.

Certified Naturally Grown: an organization of organic farms in which members certify and control the compliance with organic farming practices of other members through a peer-review system.

Community Supported Agriculture (CSA): association of a farm and its customers who guarantee the purchase of the farm's annual yield for a fixed price to share the financial risks of farming between producers and consumers. In the Ithaca Local Market Area, CSA farms commonly offer a weekly box of various foodstuffs through a subscription service during the growing season.

Environmental Quality Incentives Program (EQUIP): federal financial incentive program for landscape conservation, administrate by the NRCS.

Food Sovereignty: right to control the terms of the production and distribution of one's own food. Originally claimed by peasant organizations (Via Campesina in particular) as a universal right. It includes concrete, political demands such as access to land, among others

Food Stamps / Supplemental Nutrition Assistance Program (SNAP): federal social security program, that provides funds for food to low- and no-income people in the United States, commonly referred to by its former name Food Stamp Program

GreenStar: member-owned food cooperative in Ithaca, NY.

Price Loss Coverage (PLC): a federal commodity subsidy program, with payments based on acreage of a commodity and retail price.

National Agricultural Statistics Service (NASS): Statistical service of the USDA. Conducts the official Census of Agriculture.

Northeast Organic Farming Association (NOFA): Association of Organic Farms and official USDA Certified Organic accreditation body in the Northeastern United States.

Natural Resources Conservation Service (NRCS): USDA agency for environmental conservation in agriculture.

New York Certified Organic (NYCO): self-organized group of organic grain and dairy farmers that set up regular meeting to share experiences and educate farmers. Based in Geneva, NY.

Organic Grain Research and Information Network (OGRIN): New York based participatory research organization for organic agriculture.

United States Department of Agriculture (USDA): federal executive departure for policies regarding food, agriculture and forestry.

World Wide Opportunities on Organic Farms (WWOOF): international network of organic farms and garden that offer volunteering opportunities in agriculture and horticulture in exchange for lodging and board. "To wwoof" is a common verb among volunteers and hosts, meaning to work on a WWOOF farm. Equally, the term "wwoofer" denotes a volunteer through this network. 


\section{Bibliography}

ABT, Henry E. (1926): Ithaca. Ithaca, NY: Kellog.

"Agriculture" (n.d.). MERRIAM-WEBSTER. Online: http://www.merriamwebster.com/dictionary/agriculture (accessed 5 June 2016)

ATKINSON, Paul and HAMMERSLEY, Martyn (1998): Ethnography and Participant Observation. In: DENZIN, Norman K. and LINCOLN, Yvonna S. (Ed.): Strategies of Qualitative Inquiry. Thousand Oaks, CA, London, New Dehli: SAGE

BADGLEY, Catherine, et al. (2007): Organic agriculture and the global food supply. Renewable Agriculture and Food Systems 22: 86-108.

BENNHOLDT-THOMSEN, Veronika (1981): Subsistenzproduktion und erweiterte Reproduktion. Gesellschaft, Beiträge zur Marxschen Theorie 14: 30-51.

BENNHOLDT-THOMSEN, Veronika (2006): Subsistenzwirtschaft, Globalwirtschaft, Regionalwirtschaft. In: JOCHIMSEN, Maren A.; and KNOBLOCH, Ulrike (Eds.): Lebensweltökonomie in Zeiten wirtschaftlicher Globalisierung. Bielefeld: Kleine Verlag, 65-88.

BENNHOLDT-THOMSEN, Veronika; and MIES, Maria (1999): The subsistence perspective. Beyond the globalized economy. New York, NY: Zed Books.

BERNSTEIN, Henry (2014): Food sovereignty via the Peasant way: a sceptical view. Journal of Peasant Studies 41:6, 1031-1063.

BLEASDALE, Bradley T. (2013): Gardening vs. farming. [Web log post]. Online: http://fallcreekfarms.net/gardening-vs-farming/ (accessed 5 June 2016)

BOYLE, Mark (2012): The Moneyless Manifesto. Live Well. Live Rich. Live Free. Online: http://www.moneylessmanifesto.org/book/the-pop-model/ (accessed 30 May 2016)

CHAYANOV, Alexander V. (1966): The Theory of Peasant Economy. Homewood, IL: American Economic Association.

DIECKMANN, Jane Marsh (1986): A short history of Tompkins County. Ithaca, NY: DeWitt Historical Society of Tompkins County.

DUNBAR-ORITZ, Roxanne (2014): An Indigenous Peoples' History of the United States. Boston, MA: Beacon Press.

ETC GROUP (2009): Who will feed us? Questions for the food and climate crisis. ETC Group Communiqué 102, 1-34.

"Farm" [Def. 1] NEW OXFORD AMERICAN DICTIONARY (2013), New York: Oxford University Press.

"Farmer" [Def. 1] MERRIAM-WEBSTER. Online: http://www.merriam-webster.com/dictionary/Farmer (accessed 5 June 2016)

FLINT, R. F. (1971): Glacial and Quaternary Geology. New York, NY: Wiley and Sons.

GEHLKEN, Bernd (1995): Von der Bauerei zur Landwirtschaft. Aktuelle und historische Grünlandvegetation im Stedinger Land. In: AG Freiraum und Vegetation (Ed): Alles Quecke... Notizbuch 36 der Kasseler Schule. Kassel: Arbeitsgemeinschaft Freiraum und Vegetation. 
GREENSTAR COOPERATIVE (2016): Membership. Online: http://greenstar.coop/membership/ (accessed 6 June 2016)

HEINBERG, Richard (2007): Peak everything. Waking up to the century of declines. Gabriola, BC: New Society Publishers.

HOPPE, Robert A. (2014): Structure and Finances of U.S. Farms: Family Farm Report. 2014 Edition. Washington, D.C.: U.S. Department of Agriculture, Economic Research Service.

ILLICH, Ivan (1982): Das Recht auf Gemeinheit. Reinbek bei Hamburg: Rowohlt.

KAMMEN, Carol (1985): The Peopling of Tompkins County. A Social History. Interlaken, NY: Heart of the Lakes Publishing.

KAMMEN, Carol (2008): Ithaca. A Brief History. Charleston, SC: The History Press.

KLEIN, Naomi (2014): This changes everything: capitalism vs. the climate. New York, NY: Simon \& Schuster.

KOOPMAN, Sara (2007): Campesino. [Web log post]. Online:

http://www.spanishforsocialchange.com/2007/09/campesino.html (accessed 30 May 2016)

LACAN, Jacques (1987): Die vier Grundbegriffe der Psychoanalyse. Berlin: Weinheim.

LAMNEK, Siegfried (1995): Qualitative Sozialforschung. Volume 2: Methoden und Techniken. 3rd edition. Weinheim: Beltz Psychologie Verlags Union

LA VIA CAMPESINA (2009): Declaration of Rights of Peasants - Women and Men. Online: https://viacampesina.net/downloads/PDF/EN-3.pdf (accessed 5 June 2016)

LEACOCK, Eleanor (1987): Gender in Egalitarian Societies. In: BRIDENTHAL, Renate and KOONZ, Claudia (Eds.): Becoming Visible: Women in European History. Boston: Houghton Mifflin Company. Online: http://www.washburn.edu/cas/history/stucker/Leacock.html (accessed 13 June 2016)

LOGSDON, Gene (1985): A Farm Is a Large Garden (or a Garden Is a Small Farm). In: Gene Logsdon's Practical Skills: A Revival of Forgotten Crafts, Techniques, and Traditions. Emmaus, PA: Rodale Press.

LÜHRS, Helmut (1994): Die Vegetation als Indiz der Wirtschaftsgeschichte dargestellt am Beispiel des Wirtschaftsgrünlandes und der GrasAckerBrachen - oder Von Omas Wiese zum Queckengrasland und zurück? In: AG Freiraum und Vegetation (Ed): Notizbuch 32 der Kasseler Schule. Kassel: Arbeitsgemeinschaft Freiraum und Vegetation.

MASLOW, Abraham M. (1943): A Theory of Human Motivation. Psychological Review 50: 370-396.

McMICHAEL, Philip (2013): Historicizing Food Sovereignty: a Food Regime Perspective. Paper presented at the conference Food Sovereignty: A Critical Dialogue. 2013. New Haven, CT: Yale University Press.

MEADOWS, Donella H. (1972): The Limits to Growth. A Report for the Club of Rome's Project on the Predicament of Mankind. New York, NY: Universe Books.

MEIER KRUKER, Verena; and RAUH, Jürgen (2005): Arbeitsmethoden der Humangeographie. Darmstadt: Wissenschaftliche Buchgesellschaft. 
MOORE, Jason W. (2014): The End of Cheap Nature or: How I learned to Stop Worrying about "the" Environment and Love the Crisis of Capitalism. In: SUTER, Christian; and CHASE-DUNN, Christopher (Eds.): Structures of the World Political Economy and the Future of Global Conflict and Cooperation. Berlin: Lit Verlag.

NORTHEAST REGIONAL CLIMATE CENTER (2015): The Ithaca Climate Page. Online: http://www.nrcc.cornell.edu/wxstation/ithaca/normal.html (accessed 5 June 2016)

PATTON, Michael Q. (2002): Qualitative Evaluation and Research Methods. 3rd edition. London: Sage

POTTER, Clive; and LOBLEY, Matt (1992): Aging and Succession on Family Farms: The Impact of Decision Making and Land Use. Sociologia Ruralis 32 2/3: 317-334.

ROSSET, Peter M. (1999): The Multiple Functions and Benefits of Small Farm Agriculture in the Context of Global Trade Negotiations. Oakland, CA: Food First/Institute for Food and Development Policy.

SCHMIDTHALER, Martina (1997): Die Landnutzung im Machland-Süd landschaftsplanerisch betrachtet. Diploma thesis. Vienna: Institute of Landscape Planning, University of Natural Resources and Life Sciences.

SCHNEIDER, Gerda (2007): Die Handlungsfreiräume auf Hofwirtschaften in ländlichen Räumen werden durch die symbolische Ordnung der Mutter strukturiert. In: Arbeitsgemeinschaft Freiraum und Vegetation (Ed.): Notizbuch 75 der Kasseler Schule: Planen für die Wechselfälle des Lebens und Die 'produktive' Bedürftigkeit der angestrengten Junggesellenkultur. Kassel: n.p. 115-131.

SCHMIDTHALER, Martina (2013): Wirtschaftsäpfel - die Früchte der Frauen. Eine landschaftsplanerische Betrachtung der Wirtschaftsäpfel als Bestandteil der Hofwirtschaft im Mostviertel, Dissertation. Vienna: Institute of Landscape Planning, University of Natural Resources and Life Sciences.

SCHUMACHER, Ernst Friedrich (1973): Small is Beautiful. Economics as if People Mattered. New York, NY: Harper \& Row.

SOTTOMAYOR, Miguel; TRANTER, Richard; and COSTA, Leonardo (2011): Likelihood of Succession and Farmers' Attitudes towards their Future Behaviour: Evidence from a Survey in Germany, the United Kingdom and Portugal. International Journal of Sociology of Agriculture and Food 18/2: 121133.

SPITTLER, Gerd (1987): Tschajanow und die Theorie der Familienwirtschaft. In: TSCHAJANOW, Alexander: Die Lehre von der bäuerlichen Wirtschaft. Versuch einer Theorie der Familienwirtschaft im Landbau. Frankfurt / New York, NY: Campus Verlag.

SULLIVAN, John (1779): Journals of the Military Expedition of General John Sullivan. In: ABT, Henry E. (1926): Ithaca. Ithaca, NY: Kellog.

THORNER, Daniel (1966): Chayanov's Concept of Peasant Economy. In: CHAYANOV, Alexander V.: The Theory of Peasant Economy. Homewood, IL: American Economic Association.

VAN DER PLOEG, Jan Douwe (2008): The New Peasantries. Struggles for autonomy and sustainability in an era of empire and globalization. London: Earthscan.

VAN DER PLOEG, Jan Douwe (2013): Peasant-driven agricultural growth and food sovereignty. Paper presented at the conference Food Sovereignty: A Critical Dialogue. 2013. New Haven, CT: Yale University Press.

U.S. CENSUS BUREAU (1945): U.S. Census of Agriculture. New York State and County Data. Suitland, MD: United States Bureau of the Census. 
U.S. CENSUS BUREAU (2014a): Incorporated Places and Minor Civil Divisions Datasets: Subcounty Resident Population Estimates: April 1, 2010 to July 1, 2014. New York. Online: http://www.census.gov/popest/data/cities/totals/2014/files/SUB-EST2014_36.csv (accessed 5 June 2016)

U.S. CENSUS BUREAU (2014b): Annual Estimates of the Resident Population: April 1, 2010 to July 1, 2014. 2014 Population Estimates. Online:

http://factfinder.census.gov/faces/tableservices/jsf/pages/productview.xhtml?src=bkmk (accessed 13 May 2016)

U.S. CENSUS BUREAU (2014c): Profile of General Population and Housing Characteristics: 2010. Online: http://factfinder.census.gov/faces/tableservices/jsf/pages/productview.xhtml?src=CF (accessed 13 May 2016)

USDA (Ed.) (2002): U.S. Census of Agriculture. New York State and County Data. Washington, D.C.: National Agricultural Statistics Service. United States Department of Agriculture.

USDA (Ed.) (2007): U.S. Census of Agriculture. New York State and County Data. Washington, D.C.: National Agricultural Statistics Service, United States Department of Agriculture.

USDA (Ed.) (2012a): U.S. Census of Agriculture. United States Summary and State Data. Washington, D.C.: National Agricultural Statistics Service, United States Department of Agriculture.

USDA (Ed.) (2012b): U.S. Census of Agriculture. New York State and County Data Washington, D.C.: National Agricultural Statistics Service, United States Department of Agriculture.

USDA (2015): Land Values 2015 Summary. Washington, D.C.: National Agricultural Statistics Service, Agricultural Statistics Board, United States Department of Agriculture.

WASHINGTON, George (1779): From George Washington to Major General John Sullivan, 31 May 1779. Online: http://founders.archives.gov/documents/Washington/03-20-02-0661 (accessed 5 June 2016) 


\section{list of figures}

Figure 1: Number of farms by size in Schuyler, Seneca and Tompkins Counties (data: U.S. CENSUS BUREAU 1945, USDA 2012b)

Figure 2: farm size distribution (data: U.S. CENSUS BUREAU 1945, USDA 2012b) .........................9

Figure 3: number of farms in Schuyler, Seneca and Tompkins Counties (data: USDA 2007, USDA 2012b)

Figure 4: Farm Real Estate Value (data: USDA 2002, USDA 2007, USDA 2012b)............................. 10

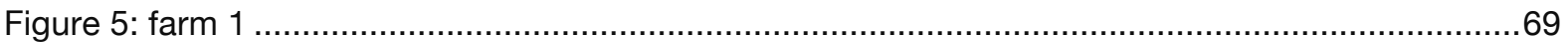

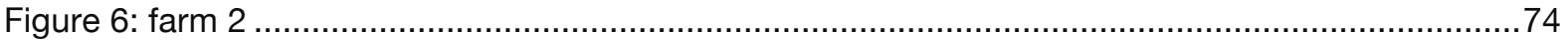

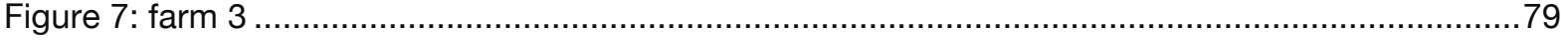

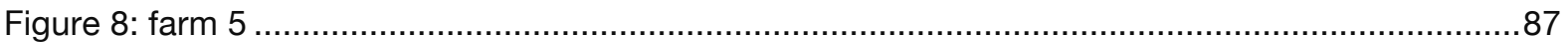

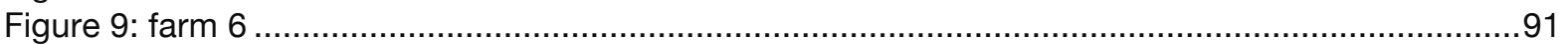

